Invited Review

\title{
The 2010-2011 Canterbury Earthquake Sequence: Environmental effects, seismic triggering thresholds and geologic legacy
}

\author{
Mark C. Quigley ${ }^{\text {a,b,* }}$, Matthew W. Hughes ${ }^{\text {b,c }}$, Brendon A. Bradley ${ }^{c}$, Sjoerd van Ballegooy ${ }^{\text {d }}$, Catherine Reid ${ }^{\text {b }}$, \\ Justin Morgenroth $^{\mathrm{e}}$, Travis Horton ${ }^{\mathrm{b}}$, Brendan Duffy ${ }^{\mathrm{a}, \mathrm{b}}$, Jarg R. Pettinga ${ }^{\mathrm{b}}$ \\ a School of Earth Sciences, The University of Melbourne, Victoria 3010, Australia \\ b Department of Geological Sciences, University of Canterbury, Christchurch 8140, New Zealand \\ c Department of Civil and Natural Resources Engineering, University of Canterbury, Christchurch 8140, New Zealand \\ ' Tonkin E' Taylor Ltd, PO Box 5271, Wellesley Street, Auckland 1141, New Zealand \\ e School of Forestry, University of Canterbury, Christchurch 8140, New Zealand
}

\section{A R T I C L E I N F O}

\section{Article history:}

Received 5 July 2015

Received in revised form 12 January 2016

Accepted 24 January 2016

Available online 12 February 2016

\section{Keywords:}

Canterbury Earthquake Sequence (CES)

Christchurch

Seismic hazard

Earthquake environmental effects

\begin{abstract}
A B S T R A C T
Seismic shaking and tectonic deformation during strong earthquakes can trigger widespread environmental effects. The severity and extent of a given effect relates to the characteristics of the causative earthquake and the intrinsic properties of the affected media. Documentation of earthquake environmental effects in wellinstrumented, historical earthquakes can enable seismologic triggering thresholds to be estimated across a spectrum of geologic, topographic and hydrologic site conditions, and implemented into seismic hazard assessments, geotechnical engineering designs, palaeoseismic interpretations, and forecasts of the impacts of future earthquakes. The 2010-2011 Canterbury Earthquake Sequence (CES), including the moment magnitude ( $\left.\mathrm{M}_{\mathrm{w}}\right) 7.1$ Darfield earthquake and $\mathrm{M}_{\mathrm{w}} 6.2,6.0,5.9$, and 5.8 aftershocks, occurred on a suite of previously unidentified, primarily blind, active faults in the eastern South Island of New Zealand. The CES is one of Earth's best recorded historical earthquake sequences. The location of the CES proximal to and beneath a major urban centre enabled rapid and detailed collection of vast amounts of field, geospatial, geotechnical, hydrologic, biologic, and seismologic data, and allowed incremental and cumulative environmental responses to seismic forcing to be documented throughout a protracted earthquake sequence. The CES caused multiple instances of tectonic surface deformation ( $\geq 3$ events), surface manifestations of liquefaction ( $\geq 11$ events), lateral spreading ( $\geq 6$ events), rockfall ( $\geq 6$ events), cliff collapse ( $\geq 3$ events), subsidence ( $\geq 4$ events), and hydrological (10s of events) and biological shifts ( $\geq 3$ events). The terrestrial area affected by strong shaking (e.g. peak ground acceleration (PGA) $\geq 0.1-0.3 \mathrm{~g}$ ), and the maximum distances between earthquake rupture and environmental response $\left(R_{\text {rup }}\right)$, both generally increased with increased earthquake $M_{w}$, but were also influenced by earthquake location and source characteristics. However, the severity of a given environmental response at any given site related predominantly to ground shaking characteristics (PGA, peak ground velocities) and site conditions (water table depth, soil type, geomorphic and topographic setting) rather than earthquake $\mathrm{M}_{\mathrm{w}}$. In most cases, the most severe liquefaction, rockfall, cliff collapse, subsidence, flooding, tree damage, and biologic habitat changes were triggered by proximal, moderate magnitude $\left(M_{w} \leq 6.2\right)$ earthquakes on blind faults. CES environmental effects will be incompletely preserved in the geologic record and variably diagnostic of spatial and temporal earthquake clustering. Liquefaction feeder dikes in areas of severe and recurrent liquefaction will provide the best preserved and potentially most diagnostic CES features. Rockfall talus deposits and boulders will be well preserved and potentially diagnostic of the strong intensity of CES shaking, but challenging to decipher in terms of single versus multiple events. Most other phenomena will be transient (e.g., distal groundwater responses), not uniquely diagnostic of earthquakes (e.g., flooding), or more ambiguous (e.g. biologic changes). Preliminary palaeoseismic investigations in the CES region indicate recurrence of liquefaction in susceptible sediments of $\sim 100$ to $300 \mathrm{yr}$, recurrence of severe rockfall event(s) of ca. 6000 to $8000 \mathrm{yr}$, and recurrence of surface rupturing on the largest CES source fault of ca. 20,000 to 30,000 yr. These data highlight the importance of utilising multiple proxy datasets in palaeoearthquake studies. The severity of environmental effects triggered during the strongest CES earthquakes was as great as or equivalent to any historic or prehistoric effects recorded in the geologic record. We suggest that the shaking caused by rupture of local blind faults in the CES comprised a 'worst case' seismic shaking scenario for parts of the Christchurch urban area. Moderate $\mathrm{M}_{\mathrm{w}}$ blind fault earthquakes may contribute the highest proportion of seismic hazard, be the most important drivers of landscape evolution, and dominate the palaeoseismic record in some locations on Earth, including locations distal
\end{abstract}

\footnotetext{
* Corresponding author at: School of Earth Sciences, The University of Melbourne, Parkville, Victoria 3010, Australia.

E-mail address: mark.quigley@unimelb.edu.au (M.C. Quigley).
} 
from any identified active faults. A high scientific priority should be placed on improving the spatial extent and quality of 'off-fault' shaking records of strong earthquakes, particularly near major urban centres.

(c) 2016 Elsevier B.V. All rights reserved.

\section{Contents}

1. Introduction .

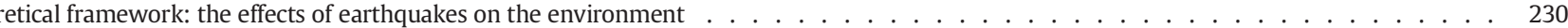

3. Seismotectonic setting of the Canterbury Earthquake Sequence (CES) . . . . . . . . . . . . . . . . . . . . . . . . . . . . . . . . . . 233

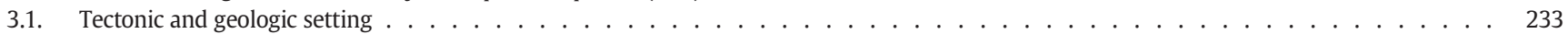

3.2. Pre-CES historical seismicity . . . . . . . . . . . . . . . . . . . . . . . . . . . . . . . . . . . . . . . 235

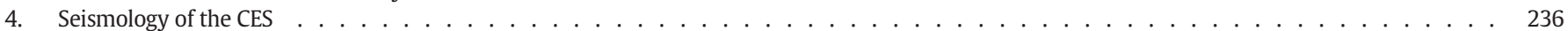

4.1. Introduction . . . . . . . . . . . . . . . . . . . . . . . . . . . . . . . . . . . . . . . . . . 236

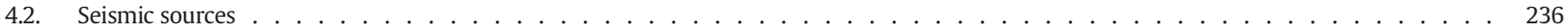

4.3. Characteristics of the CES aftershock sequence . . . . . . . . . . . . . . . . . . . . . . . . . . . . . . . . . . . . . . . 237

4.4. Ground motion aspects of the CES . . . . . . . . . . . . . . . . . . . . . . . . . . . . . . . . . 237

4.4.1. Summary of observations . . . . . . . . . . . . . . . . . . . . . . . . . . . . . . . . . . . . . . . . . . 237

4.4.2. Comparison of empirical predictions . . . . . . . . . . . . . . . . . . . . . . . . . . . . . . . . . . . . . 239

4.4.3. Specific strong motion features observed . . . . . . . . . . . . . . . . . . . . . . . . . . . . . . . . . . . 239

5. CES Environmental effects, seismologic thresholds, and palaeoseismic implications . . . . . . . . . . . . . . . . . . . . . . . . . . . . . 240

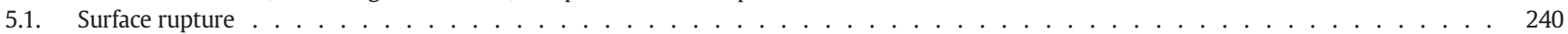

5.1.1. Effects and distribution . . . . . . . . . . . . . . . . . . . . . . . . . . . . . . . . . . . . . . . . . 240

5.1.2. Seismic triggering thresholds . . . . . . . . . . . . . . . . . . . . . . . . . . . . . . . . . 242

5.1.3. Palaeoseismic implications . . . . . . . . . . . . . . . . . . . . . . . . . . . . . . . . . . . . . . . . . . . . . 242

5.2. Surface deformation above blind faults . . . . . . . . . . . . . . . . . . . . . . . . . . . . . . . . . . . . . . . . . . 242

5.2.1. Effects and distribution . . . . . . . . . . . . . . . . . . . . . . . . . . . . . . . . . . . . . . . . . . . . . 242

5.2.2. Seismic triggering thresholds . . . . . . . . . . . . . . . . . . . . . . . . . . . . . . . . . . . . . 244

5.2.3. Palaeoseismic implications . . . . . . . . . . . . . . . . . . . . . . . . . . . . . . . . . . . . . 244

5.3. River avulsion, river gradient changes, and flooding . . . . . . . . . . . . . . . . . . . . . . . . . . . . . . . . . 244

5.3.1. Effects and distribution . . . . . . . . . . . . . . . . . . . . . . . . . . . . . . . . . . . . . . . . . . . 244

5.3.2. Seismic triggering thresholds . . . . . . . . . . . . . . . . . . . . . . . . . . . . . . . . . . . 247

5.3.3. Palaeoseismic implications . . . . . . . . . . . . . . . . . . . . . . . . . . . . . . . . . . . . . . . . 247

5.4. Liquefaction, lateral spreading and subsidence effects . . . . . . . . . . . . . . . . . . . . . . . . . . . . . . . . . . . . . . . . 249

5.4.1. Effects and distribution . . . . . . . . . . . . . . . . . . . . . . . . . . . . . . . . . . 249

5.4.2. Seismic triggering thresholds . . . . . . . . . . . . . . . . . . . . . . . . . . . . . . . . . 255

5.4.3. Palaeoseismic implications . . . . . . . . . . . . . . . . . . . . . . . . . . . . . . . 257

5.5. Mass movements: rockfall, cliff collapse, landsliding, boulder displacements and rock fragmentation . . . . . . . . . . . . . . . . . . . 258

5.5.1. Effects and distribution . . . . . . . . . . . . . . . . . . . . . . . . . . . . . . . . . . . . . 258

5.5.2. Seismic thresholds . . . . . . . . . . . . . . . . . . . . . . . . . . . . . . . . . . . . . . 259

5.5.3. Palaeoseismic implications . . . . . . . . . . . . . . . . . . . . . . . . . . . . . . . . . . . . 261

5.6. Groundwater hydrologic effects . . . . . . . . . . . . . . . . . . . . . . . . . . . . . . . . . . . . . . . . . 262

5.6.1. Effects and distribution . . . . . . . . . . . . . . . . . . . . . . . . . . . . . . . . . . . . . . . . . 262

5.6.2. Seismologic thresholds . . . . . . . . . . . . . . . . . . . . . . . . . . . . . . . . . . . . . . . . . . 264

5.6.3. Palaeoseismic implications . . . . . . . . . . . . . . . . . . . . . . . . . . . . . . . . . . . . . . . 264

5.7. Effects on trees and other flora and fauna . . . . . . . . . . . . . . . . . . . . . . . . . . . . . . . . . . 265

5.7.1. Effects and distribution . . . . . . . . . . . . . . . . . . . . . . . . . . . . . . . . . . . . . . . . . . . 265

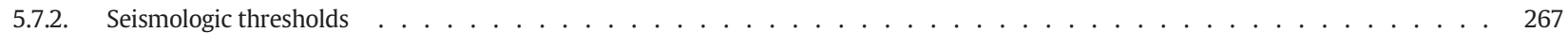

5.7.3. Palaeoseismic implications . . . . . . . . . . . . . . . . . . . . . . . . . . . . . . . . . . . . . . 267

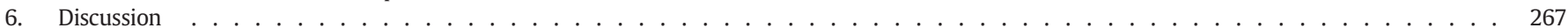

6.1. Summary of earthquake environmental effects and relationships to site conditions, seismologic triggering thresholds, and preceding earthquakes 267

6.2. Geologic legacy of the CES and palaeoseismic implications . . . . . . . . . . . . . . . . . . . . . . . . . . . 268

6.3. Is the CES over? . . . . . . . . . . . . . . . . . . . . . . . . . . . . . . . . . . . 269

7. Conclusions . . . . . . . . . . . . . . . . . . . . . . . . . . . . . . . . . . . . . . 269

Acknowledgements . . . . . . . . . . . . . . . . . . . . . . . . . . . . . . . . . . . . . . . 271

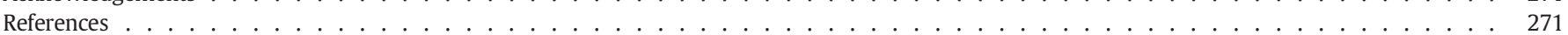

\section{Introduction}

Many damaging and fatal earthquakes of moderate moment magnitude ( $\sim \mathrm{M}_{\mathrm{w}} 5.5$ to 6.9 ) are sourced from faults that do not cause discrete surface rupture (i.e. blind faults) and thus leave no direct surface evidence for seismogenic faulting. Recent historical examples include the $2014 \mathrm{M}_{\mathrm{w}} 6.2$ Mae Lao, Thailand (2 fatalities), $2012 \mathrm{M}_{\mathrm{w}} 5.9$ and 5.8 Emilia-Romagna, Italy (27 fatalities, \$17 B USD damage), 2011 $\mathrm{M}_{\mathrm{w}} 5.8$ Mineral, Virginia, U.S.A. (>\$200 M USD damage), $2011 \mathrm{M}_{\mathrm{w}} 6.2$ Christchurch, New Zealand (NZ) (185 fatalities, \$ 15 B USD damage, part of an earthquake sequence with damage exceeding \$30 B USD),
$2003 \mathrm{M}_{\mathrm{w}} 6.5$ Bam, Iran (>26000 fatalities), $1994 \mathrm{M}_{\mathrm{w}} 6.7$ Northridge, U.S.A. (57 fatalities, $\$ 15$ B USD damage), $1994 \mathrm{M}_{\mathrm{w}} 6.9$ Loma Prieta, U.S.A. (63 fatalities, $\$ 10$ B USD damage), $1987 \mathrm{M}_{\mathrm{w}} 6.0$ Whittier Narrows, U.S.A. (10 fatalities), and $1983 \mathrm{M}_{\mathrm{w}} 6.5$ Coalinga, U.S.A. ( $\$ 10 \mathrm{M}$ USD damage) events. Fault populations and earthquake frequencymagnitude distributions typically adhere to Gutenberg-Richter (G-R) scaling (Main, 1996). This implies that unmapped smaller active blind faults with lower $\mathrm{M}_{\mathrm{w}}$ potentials may greatly exceed the number of mapped larger faults with larger $\mathrm{M}_{\mathrm{w}}$ potentials that have been identified based on surface evidence for faulting (e.g. Nicol et al., 2011). To address this issue, probabilistic seismic hazard analysis (PSHA) typically 
combines seismic source data (i.e. mapped faults with subsurface rupture lengths $\left[R L_{\text {sub }}\right]$ estimated from the scaling of surface rupture lengths [SRL]) with distributed historical seismicity to construct seismic hazard curves (e.g., Stirling et al., 2012; Petersen et al., 2008; Giardini et al., 2013). In areas distal from identified active faults, distributed seismicity from unspecified faults will contribute to the seismic hazard, with increasing contributions from proximal, moderate $\mathrm{M}_{\mathrm{w}}$ earthquakes towards higher shaking intensities (Stirling et al., 2008). Blind faults thus pose a major seismic hazard to many urban environments on Earth (e.g., Shaw and Suppe, 1996; Berberian, 1995; Burrato et al., 2003).

The $\mathrm{M}_{\mathrm{w}}$ and recurrence intervals of past earthquakes sourced from blind or otherwise unmapped faults are difficult to obtain directly, particularly if these faults have not ruptured historically. 'Secondary' off-fault proxies of strong ground motion may thus have value in providing information on the recurrence and characteristics of past earthquakes, including those that may be sourced from blind or otherwise unmapped faults (e.g., Mackey and Quigley, 2014; Bastin et al., 2015; Maurer et al., 2015). The reliable use of geologic features to characterise past earthquakes requires an understanding of the seismologic and geologic conditions under which these features were formed and preserved within the geologic record. Contemporary earthquakes, where highresolution seismic and geospatial data are typically available and able to be combined with detailed field observations, provide opportunities to document earthquake effects for the purpose of (1) determining the seismic conditions under which earthquake phenomena are induced, (2) determining the environmental conditions under which earthquake-induced features are formed and preserved in the geologic record, (3) assessing the completeness and fidelity of palaeoseismic records, and (4) forecasting the likely recurrence intervals, locations, and effects of future earthquake strong ground motions based on the characteristics and recurrence intervals of past ground motions (e.g., Quigley et al., 2013; Mackey and Quigley, 2014).

This paper provides a comprehensive summary of environmental effects induced by the 2010-2011 Canterbury Earthquake Sequence (CES) in New Zealand's South Island. We first provide a generalised theoretical framework for how earthquakes impact the environment. We then present a summary of CES geological, topographic, hydrological, and biological environmental effects and compare these to measurements of earthquake size $\left(\mathrm{M}_{\mathrm{w}}\right)$ and shaking characteristics such as peak ground acceleration (PGA) and peak ground velocity (PGV). We discuss the potential of different types of CES-induced effects to be preserved in the geologic record, and provide evidence for pre-CES earthquake-induced features recently identified in the study region. A key conclusion of this paper is that geologic features resulting from past earthquakes, including those sourced from blind and/or unmapped faults, are likely to be present in the geologic record and provide evidence of the most hazardous locations in future earthquakes.

\section{Theoretical framework: the effects of earthquakes on the environment}

Crustal displacement during fault rupture creates seismic waves with properties that reflect the characteristics of the source fault and the associated rupture (Fig. $1 \mathrm{~A}$ ). In the near-field (i.e., close to the fault), body and surface wave amplitudes, frequency content (freq content; Fig. 1) and durations are most strongly influenced by fault rupture area (RA), coseismic displacement (D), shear modulus $(\mu)$, and average static $\left(\Delta \sigma_{s}\right)$ and dynamic stress drops $\left(\Delta \sigma_{d}\right)$ that collectively comprise the moment magnitude $\left(\mathrm{M}_{\mathrm{w}}\right)$ and radiated seismic energy $\left(E_{s}\right)$ or energy magnitude of the earthquake. Other rupture characteristics that influence seismic wave properties include the rupture directivity, rupture velocity $\left(V_{R}\right)$, and slip duration at any given point (i.e., risetime; $\left.D_{t}\right)$, rupture kinematics $\left(R_{\text {kin }}\right.$; normal, strike-slip, reverse), and rupture extent ( $R_{\text {ext }}$; i.e. surface rupturing versus 'blind' and strike dimension). Rupture characteristics relate to the 3-dimensional fault geometry and orientation, and the physical, chemical, and hydrologic properties of the fault including fault zone mineralogy and pore fluid pressures (PFP) that influence the static $\left(\mu_{\mathrm{s}}\right)$ and dynamic $\left(\mu_{\mathrm{d}}\right)$ frictional characteristics of fault rocks (Fig. 1A). Fault properties may vary in time and space in part due to the tectonic setting and associated crustal strain rate, the recurrence interval of ruptures, interseismic processes including fault annealing, and the composition of the lithosphere in the fault region. Recent, well-documented continental earthquakes (e.g., Hayes et al., 2010; Fletcher et al., 2014; Ozacar and Beck, 2004) suggest that complex ruptures involving multiple faults (Fig. 1A) with variable coseismic slip distributions may be more common than structurally 'simple' ruptures (Quigley, 2013). Hypocentral locations, coseismic slip distributions, magnitudes, and rupture propagation directions may vary from earthquake to earthquake (Barbot et al., 2012), even on fault segments typically considered to be amongst the most characteristic in terms of rupture behaviour (e.g., Parkfield segment of the San Andreas Fault). A summary of selected effects of earthquake surface rupturing, including deformation of natural features, infrastructure lifelines and built structures, appears in Fig. 1B (see caption for explanation of 1-7).

Seismic waves propagating beyond the near-field to a given site are variably modified, attenuated, and/or amplified as a function of sourceto-site distance, ray path effects, lithospheric composition and structure, soil and rock characteristics, and surface and subsurface topography (Fig. 1A). As a consequence, seismic wave characteristics typically vary significantly from source-to-site and amongst different sites (e.g. Sites A-F; Fig. 1A), even over small $(<1 \mathrm{~km}$ ) distances (Bradley et al., 2014; Bradley, 2012a, 2012b; Bradley and Cubrinovski, 2011a, 2011b; Shakal et al., 2006; Hanks and Brady, 1991; Somerville et al., 1996). Instrumentally-recorded waveforms are analysed to derive measures of (i) seismic shaking intensity such as peak ground displacements, PGV, and PGA, (ii) duration of shaking, and (iii) frequency content (e.g., spectral intensities). In general, the seismic wave amplitude, PGV and PGA will decrease with increasing distance from the seismic source, although the source-to-site distance can vary significantly depending on what aspect of the seismic source is used for this measurement (R1-R5; Fig. 1A). The areal extent, duration, predominant periods, and peak intensities of strong shaking will typically increase with increasing earthquake $\mathrm{M}_{\mathrm{w}}$ (Table 1 ), although the rupture process and site characteristics described above all exert significant influences.

Shaking-induced environmental phenomena (Fig. 1C) such as landslides, rockfalls, cliff collapses, liquefaction and subsidence are initiated above different thresholds of seismic shaking. The seismologic conditions required to trigger these phenomena, termed creation thresholds by Nelson et al. (2006) are referred to as seismic triggering thresholds in this paper. Spatial variations in geology, geomorphology, topography and hydrology influence (i) the characteristics of seismic shaking (i.e. site effects), (ii) whether an environmental response is triggered under imposed seismic shaking, and (iii) how a given environmental response is manifested and preserved at a given site. The spatial distribution of shaking-induced effects (e.g., the distance from seismic source to most distal earthquake effect) typically increases with increasing earthquake $\mathrm{M}_{\mathrm{w}}$ (Table $\mathrm{S} 1$; electronic supplement) (e.g., Ambraseys, 1988; Keefer, 2002; Galli, 2000; Michetti et al., 2007). However, the density and/or severity of shaking-induced effects at an individual site typically increase with increasing shaking intensity and/or shaking duration at the site (e.g., Quigley et al., 2013; Mackey and Quigley, 2014; Massey et al., 2014).

The practise of describing earthquake-generated landscape effects to provide information on the seismogenic process has been conducted for well over a century (e.g., Sarconi, 1784; Mallet, 1862; McKay, 1890; Oldham, 1899; Lawson and Reid, 1908; Reid, 1910; Aguilera, 1920). However, increasing spatial coverage and technological improvements in instrumental seismology (e.g., see reviews in Aki and Richards, 2002; Trifunac and Todorovska, 2001), and the emergence of geospatial data including Interferometric Synthetic Aperture Radar (InSAR) (Massonnet et al., 1993), Global Positioning System (GPS) (Lisowski 

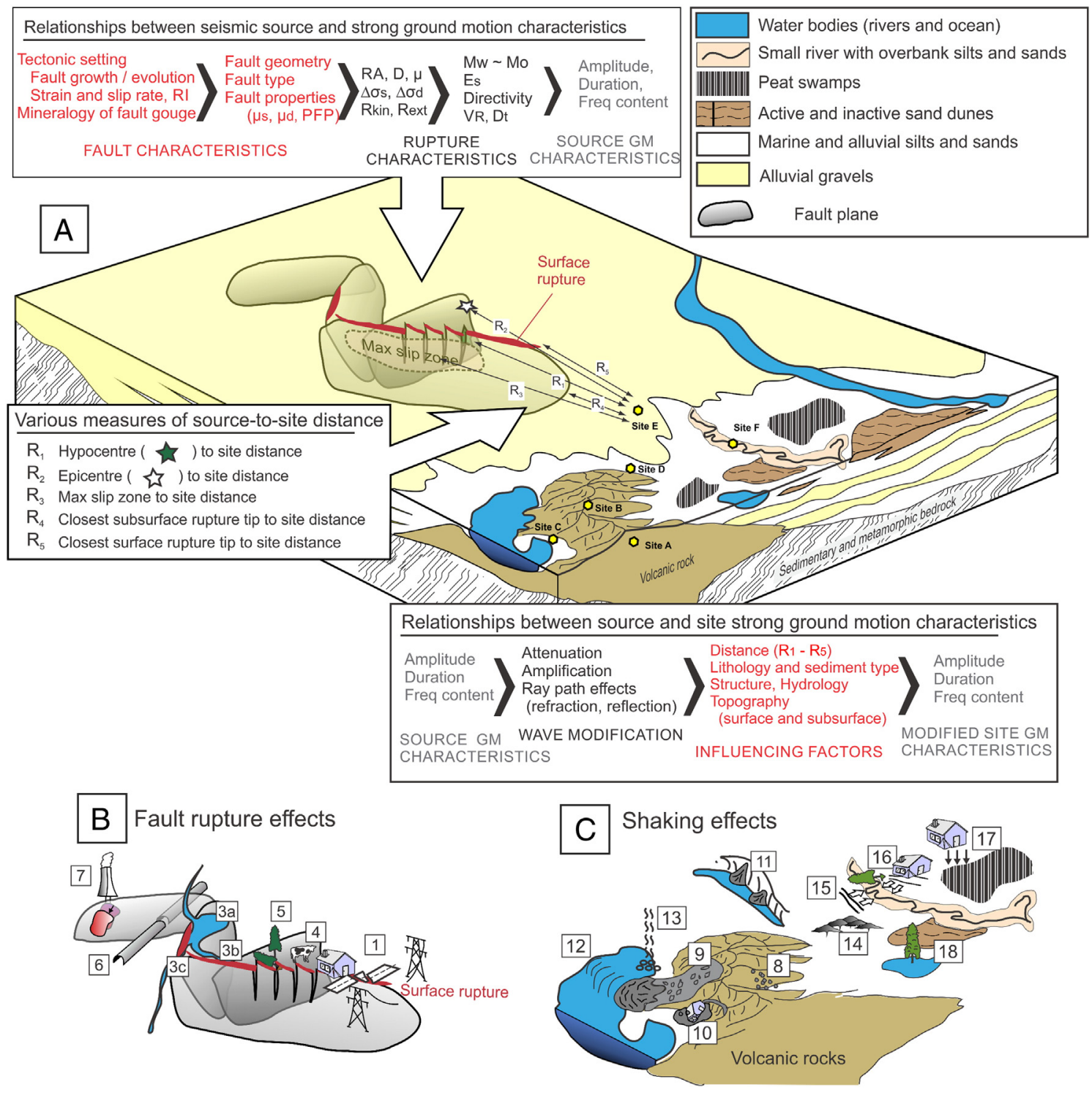

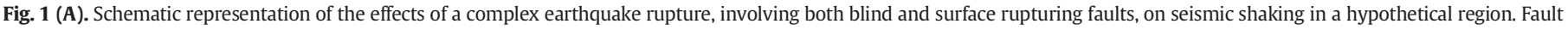

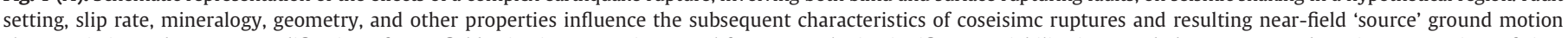

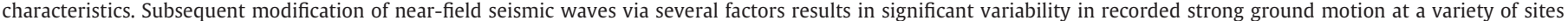

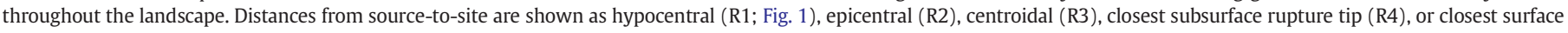

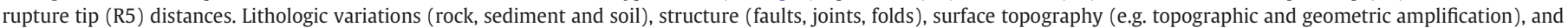

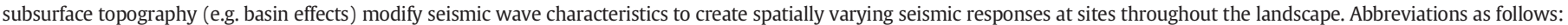

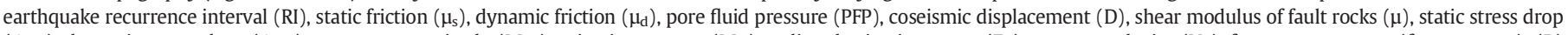

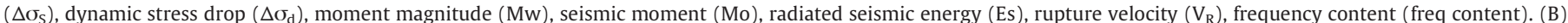

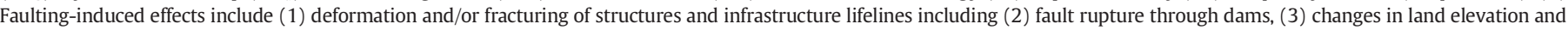

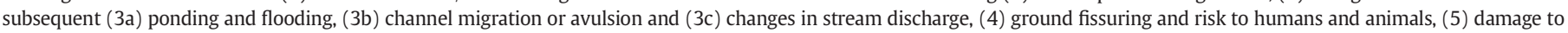

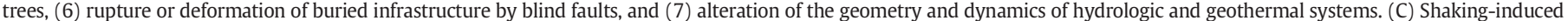

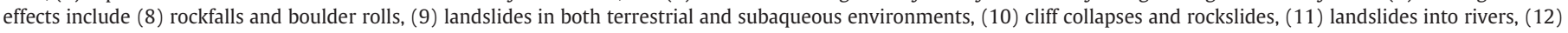

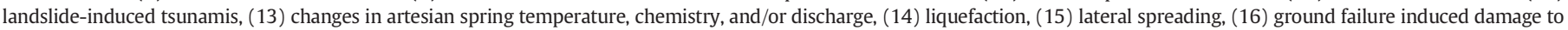
surface and subsurface structures and lifelines, (17) surface subsidence, and (18) submergence of natural and built environments near water bodies.

et al., 1990) and Light Detection and Ranging (LiDAR) (Hudnut et al., 2002) have greatly increased the resolution with which earthquakes and their environmental effects can be documented. Rapid collection of LiDAR data after surface-rupturing earthquakes is now common practise (e.g., Quigley et al., 2012; Oskin et al., 2012). In some instances, preand post-earthquake LiDAR-derived terrain differencing has enabled mapping of high (decimetre) resolution faulting-induced surface displacements (Duffy et al., 2013; Oskin et al., 2012). LiDAR differencing has recently been used to document topographic changes induced by blind faulting and earthquake shaking throughout an earthquake sequence (Hughes et al., 2015). The integration of geospatial, geodetic and seismologic data have improved the quality of fault rupture models and the understanding of rupture dynamics (e.g., Elliott et al., 2012; Beavan et al., 2012; Hartzell et al., 2013). Global compilations of empirical data from earthquake-triggered landslides (e.g., Keefer, 2002), liquefaction features (e.g., Ambraseys, 1988) and fault surface ruptures (e.g., Wells and Coppersmith, 1994; Wesnousky, 2008) have provided insights into how the characteristics and spatial distributions of earthquake phenomena vary with measures of earthquake magnitude and shaking intensity.

Despite these advances in documenting contemporary earthquakes, the palaeoseismic record is important for characterising seismic hazard 
Table 1

CES seismologic data.

\begin{tabular}{|c|c|c|c|c|c|c|c|c|c|c|}
\hline $\begin{array}{l}\text { Earthquake name and date } \\
\text { (year month day hour) (UTC) }\end{array}$ & Latitude $^{\mathrm{a}}$ & Longitude $^{\mathrm{a}}$ & $\mathrm{M}_{\mathrm{L}}^{\mathrm{b}}$ & $\mathrm{M}_{\mathrm{w}}^{\mathrm{b}}$ & $\begin{array}{l}\text { PGA } \\
\text { horizontal } \\
(\mathrm{g})^{\mathrm{c}}\end{array}$ & $\begin{array}{l}\text { PGV } \\
\text { horizontal } \\
\left(\mathrm{cm} \mathrm{s}^{-1}\right)^{\mathrm{c}}\end{array}$ & $\begin{array}{l}\text { PGA } \\
\text { vertical } \\
(\mathrm{g})^{\mathrm{C}}\end{array}$ & $\begin{array}{l}\text { Terrestrial area } \\
\left(\mathrm{km}^{2}\right) \text { with } \\
\mathrm{PGA} \geq 0.1^{\mathrm{d}}\end{array}$ & $\begin{array}{l}\text { Terrestrial area } \\
\left(\mathrm{km}^{2}\right) \text { with } \\
\mathrm{PGA} \geq 0.2^{\mathrm{d}}\end{array}$ & $\begin{array}{l}\text { Terrestrial area } \\
\left(\mathrm{km}^{2}\right) \text { with } \\
P G A \geq 0.3^{\mathrm{d}}\end{array}$ \\
\hline $\mathrm{M}_{\mathrm{w}}$ 7.1 Darfield earthquake (2010.09.03.1635) & -43.538 & 172.164 & 7.1 & 7.1 & 0.76 & 115 & 1.3 & 9230 & 3600 & 1300 \\
\hline October aftershock (2010.10.18.2232) & -43.626 & 172.564 & 5.1 & 4.8 & 0.28 & 16 & 0.21 & 221 & 36 & 0 \\
\hline Boxing Day aftershock (2010.12.25.2130) & -43.554 & 172.662 & 4.9 & 4.7 & 0.27 & 18 & 0.52 & 174 & 24 & 0 \\
\hline $\begin{array}{l}\mathrm{M}_{\mathrm{w}} 6.2 \text { Christchurch earthquake } \\
\quad(2011.02 .21 .2351)\end{array}$ & -43.566 & 172.691 & 6.3 & 6.2 & 1.41 & 81 & 2.21 & 1700 & 630 & 260 \\
\hline February aftershock I (2011.02.22.0004) & -43.589 & 172.661 & 5.8 & 5.5 & 0.56 & 44 & 0.93 & 550 & 380 & 120 \\
\hline February aftershock II (2011.02.22.0150) & -43.590 & 172.634 & 5.9 & 5.6 & 0.75 & 29 & 0.69 & 700 & 380 & 180 \\
\hline April aftershock (2011.04.16.0549) & -43.613 & 172.760 & 5.3 & 5 & 0.68 & 32 & 0.48 & 280 & 127 & 25 \\
\hline June aftershock (2011.06.13.0101) & -43.568 & 172.753 & 5.6 & 5.3 & 0.45 & 28 & 0.69 & 860 & 240 & 100 \\
\hline $\begin{array}{l}M_{w} 6.0 \text { Christchurch earthquake } \\
\quad(2011.06 .13 .0220)\end{array}$ & -43.564 & 172.743 & 6.4 & 6 & 1.54 & 102 & 1.14 & 1120 & 310 & 170 \\
\hline June 21 aftershock (2011.06.21.1034) & -43.599 & 172.525 & 5.4 & 5.2 & 0.26 & 11 & 0.62 & 494 & 112 & 25 \\
\hline December $\mathrm{M}_{\mathrm{w}} 5.8$ earthquake (2011.12.23.0058) & -43.486 & 172.796 & 5.9 & 5.8 & 0.31 & 30 & 0.98 & 550 & 95 & 0 \\
\hline December $\mathrm{M}_{\mathrm{w}} 5.9$ earthquake (2011.12.23.0218) & -43.530 & 172.743 & 6 & 5.9 & 0.44 & 44 & 0.39 & 740 & 200 & 80 \\
\hline
\end{tabular}

a Epicentral latitude and longitude in decimal degrees.

b Earthquake Richter magnitude $\left(\mathrm{M}_{\mathrm{L}}\right)$ and moment magnitude $\left(\mathrm{M}_{\mathrm{w}}\right)$ from Geonet (www.geonet.org.nz).

c Processed vertical and geometric mean horizontal peak ground accelerations and velocities from Geonet time series and Bradley et al. (2014).

d Areas estimated using interpolation of recorded strong ground motions; method outlined in Bradley (2014); areal extents refer to terrestrial (includes onshore and estuary) environments only.

because: (i) the expected recurrence interval of earthquakes on a given fault commonly exceeds the historical record by $>10^{2}$ to $10^{4} \mathrm{yr}$, (ii) recurrence intervals of the most severe, damaging strong ground motions at a given site commonly exceed the historical record by $>10^{2}$ to $10^{4}$ yrs, and (iii) earthquakes cluster in time and space over $<1$ to $>10^{3}$ yr timescales (e.g., Ambraseys, 1971; Lee and Brillinger, 1979; Ambraseys and Melville, 1982; Vere-Jones and Ozaki, 1982; Ogata, 1988; Wallace,
1987; Crone and Omdahl, 1987; Marco et al., 1996), implying that future seismicity rates may vary significantly from those derived from historical seismicity and predicted from contemporary strain rates. However, the geologic record of palaeoearthquakes is incomplete (e.g., McCalpin, 2009) because (i) many earthquakes have magnitudes and/or shaking intensities too small to produce surface or shallow subsurface evidence of their occurrence, (ii) geologic evidence of

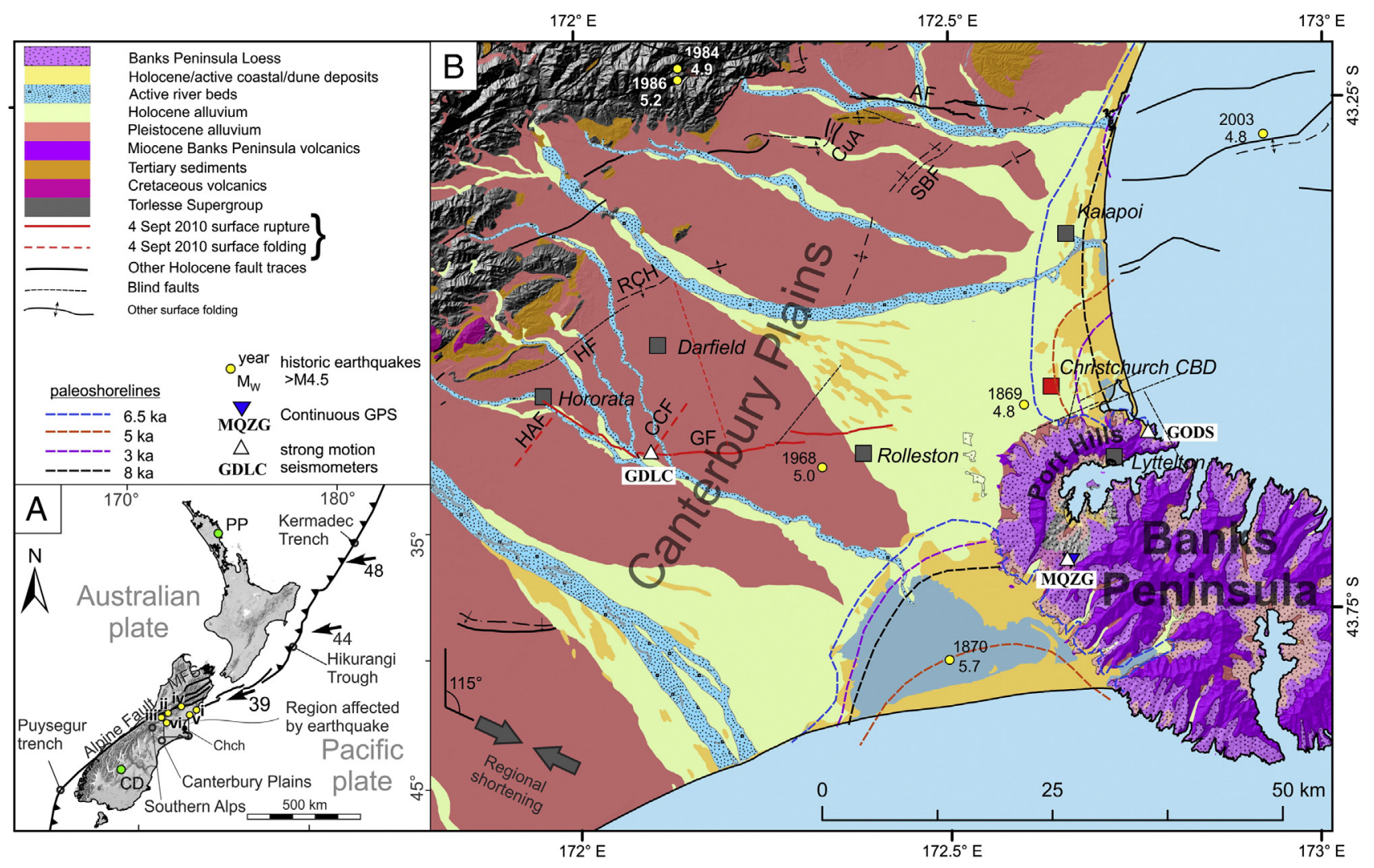

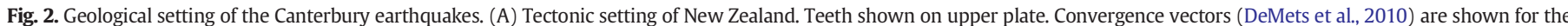

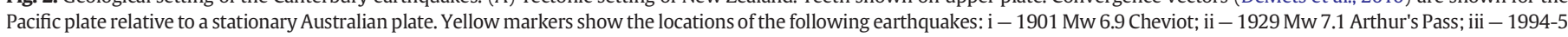

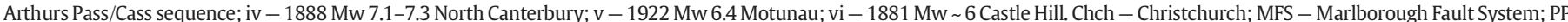

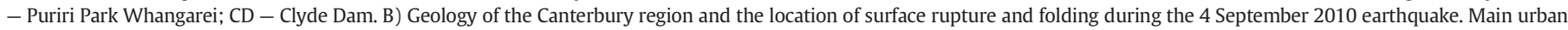

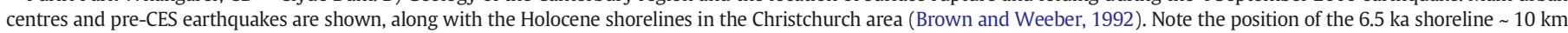
inland from the present shoreline. Regional shortening direction is from Sibson et al. (2011). 
palaeoearthquakes is commonly modified, obscured, or removed by natural processes (including erosion, sedimentation, and/or subsequent earthquakes) and/or anthropogenic activity (e.g., deforestation, farming, urban development), (iii) geologic features induced by palaeoearthquakes may not be easily discernible from other non-seismic phenomena, and (iv) temporal and spatial variations in rupture characteristics and site characteristics, and challenges with establishing robust chronologies, complicate the unambiguous attribution of an identified earthquake feature to a specific fault source, palaeoearthquake and/ or earthquake sequence.

Documenting the environmental effects of historical earthquakes, how they relate in extent and character with respect to seismicity, and whether they will be preserved and interpretable in the geologic record has the potential to greatly improve the interpretation of the palaeoseismic record. Palaeoseismic investigations at sites affected by contemporary earthquakes have the added benefit of examining how reliably palaeoseismic features could have pre-emptively forecast the effects of subsequent earthquakes (e.g., Bastin et al., 2015). Here, we synthesise the results from a wealth of recently published and until now unpublished studies of the CES to document the environmental effects, seismic triggering thresholds, and geologic legacy of a spatially and temporally clustered sequence of earthquakes sourced primarily from blind fault ruptures. Despite extensive urbanisation, agricultural development, and other anthropogenic and natural modifications, the
CES has imparted geologic and geomorphic signals that will persist for $>10^{3}$ to $10^{4} \mathrm{yrs}$, and thus provide information on the timing, source and characteristics of the causative earthquakes in this sequence.

\section{Seismotectonic setting of the Canterbury Earthquake Sequence (CES)}

\subsection{Tectonic and geologic setting}

The CES occurred in the Canterbury region of the eastern South Island of New Zealand (NZ) (Fig. 2). CES epicentre locations span an area of $\sim 1800 \mathrm{~km}^{2}(\sim 100 \mathrm{~km} \mathrm{E}-\mathrm{W} ; \sim 13$ to $35 \mathrm{~km} \mathrm{~N}-\mathrm{S})$ extending from the eastern margin of the Southern Alps to approximately $10 \mathrm{~km}$ offshore into the Pacific Ocean in Pegasus Bay (Fig. 3). The western fringe of the CES region is approximately $80 \mathrm{~km}$ east of the Alpine Fault, which accommodates $\sim 75 \%$ of the $\sim 38 \mathrm{~mm} \mathrm{yr}^{-1}$ of relative Pacific-Australian plate motion, and east of the Southern Alps, which accommodate a further $\sim 20 \%$ of plate motion via distributed active faulting (Fig. 2 inset) (Wallace et al., 2007; Stirling et al., 2012; Litchfield et al., 2014). Pre-earthquake GPS measurements indicated regional strain rates of $\sim 16$ nanostrain $\mathrm{yr}^{-1}\left(\sim 2 \mathrm{~mm} \mathrm{yr}^{-1}\right)$ shortening with a $\left(\sigma_{1}\right)$ azimuth of $110-120^{\circ}$ over an $\sim 150 \mathrm{~km}$ wide region defined as the Canterbury Block (Wallace et al., 2007) that includes the CES area (Fig. 2). Strain rates (Wallace et al., 2007), pre-CES historical seismicity

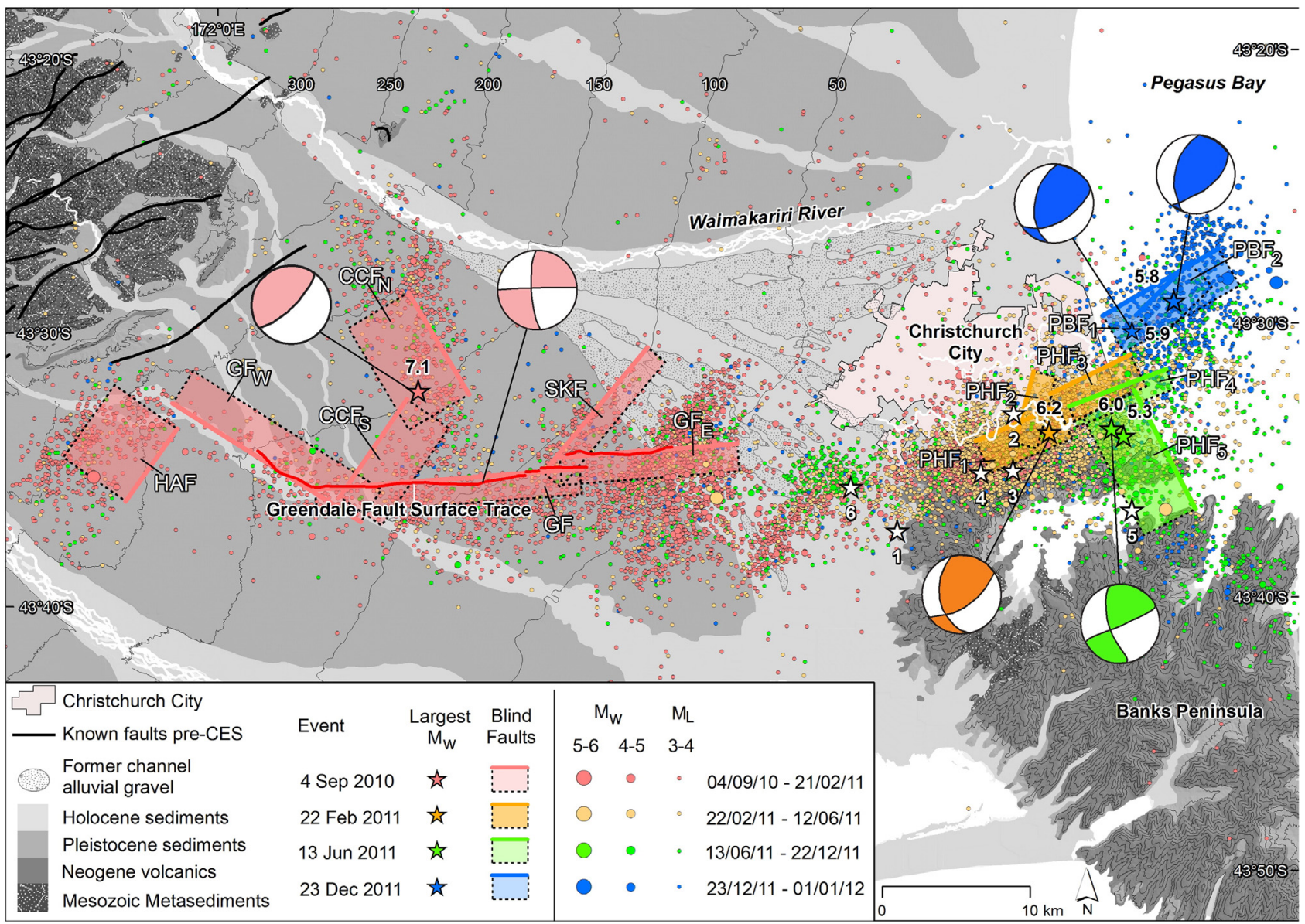

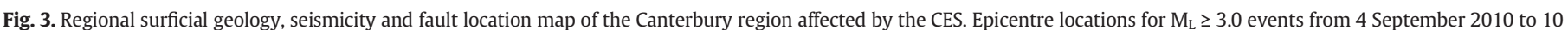

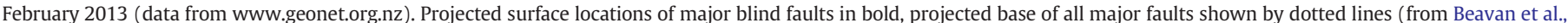

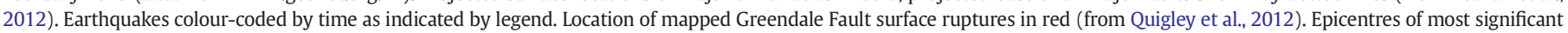

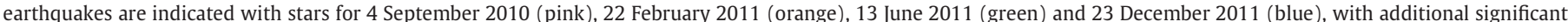

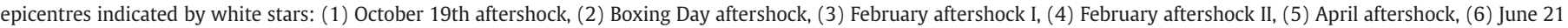

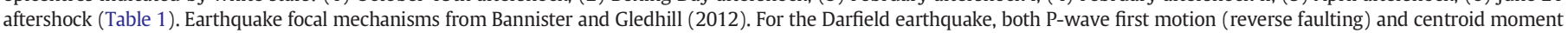
tensor (strike-slip faulting) are shown. 50-meter elevation contours also shown. 
rates (Stirling et al., 2012), and fault slip rates and earthquake recurrence intervals (e.g., Hornblow et al., 2014) are lower in the CES region compared to more tectonically active parts of the diffuse plate boundary zone (Howard et al., 2005) but higher than seismically active 'intraplate' settings located further from plate boundary zones (e.g. Quigley et al.,
2006, 2010a). The CES region is thus best typified as a tectonically active but comparatively low strain rate domain at the periphery of a diffuse plate boundary orogen.

Basement rocks in the CES region consist of a 10-12 km thick sequence of deformed, Carboniferous to Lower Cretaceous, sedimentary

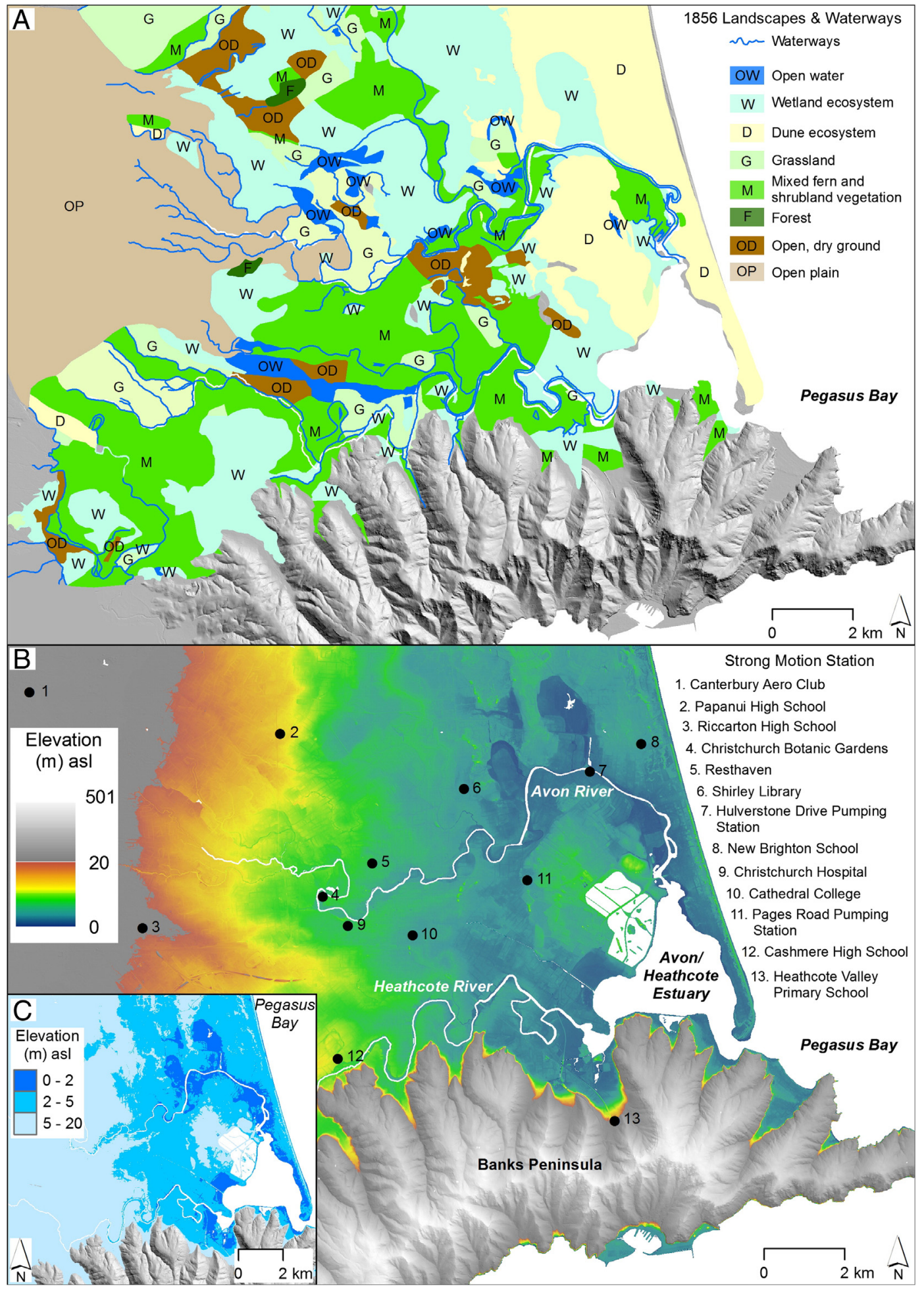

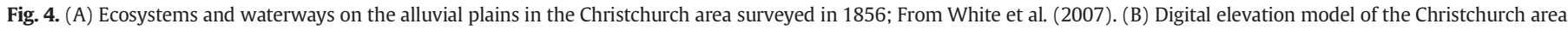

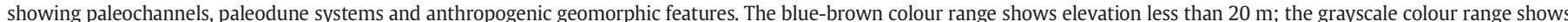

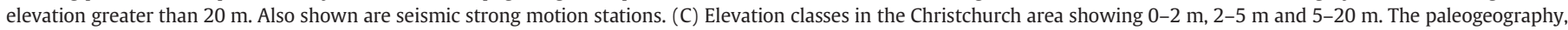

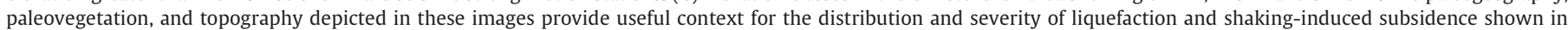
subsequent figures. 
and meta-sedimentary rocks of the Torlesse composite terrane (Bradshaw, 1989; Forsyth et al., 2008) that overlie an $~ 35 \mathrm{~km}$ thick subducted ocean plateau (Hikurangi Plateau) (Reyners et al., 2014). The regional basement crustal structure consists of Late Cretaceous grabens bound by roughly east-west aligned normal faults that have been variably reactivated from the Neogene to present throughout the Canterbury region (Fig. 2) (Jongens et al., 2012; Ghisetti and Sibson, 2012). A suite of E-W and NE-SW striking active faults have been identified throughout the Canterbury Plains based on (i) faulting and folding of Neogene to Holocene sediments at the surface (e.g., Pettinga et al., 2001; Campbell et al., 2012), (ii) onshore and offshore seismic reflection surveys (Dorn et al., 2010; Barnes et al., 2011), (iii) gravity and aeromagnetic geophysical surveys (Davy et al., 2012; Lawton et al., 2011), and (iv) correspondence of identified faults with contemporary seismicity (Ghisetti and Sibson, 2012). The east-west striking Greendale Fault ('GF' in Fig. 2), which ruptured during the 4 September $2010 \mathrm{M}_{\mathrm{w}}$ 7.1 Darfield earthquake (henceforth $\mathrm{M}_{\mathrm{w}}$ 7.1 Darfield earthquake), is most likely a reactivated Late Cretaceous normal fault on the basis of geometric similarity with other structures with documented Cretaceous ancestry (Nicol, 1993), including possible 'evolved' analogues (e.g., Ashley fault in North Canterbury, Jongens et al., 2012). The E-W strike and oblique right-lateral reverse displacements of these structures are consistent with the prevailing stress field (Campbell et al., 2012).

Basement rocks are regionally overlain by $1-2 \mathrm{~km}$ of less-indurated Cretaceous-Neogene rocks and unconsolidated Quaternary sediments. Only a few kilometres southeast of Christchurch city, the crustal structure is disrupted by ca. 12.5-6.0 Ma composite, coalescing, intraplate volcanoes that form Banks Peninsula (Hampton and Cole, 2009). West of the city, the Canterbury Plains were formed by a series of coalescing alluvial fans comprising mainly gravels deposited by the river systems draining the Southern Alps (Alloway et al., 2007; Cox and Barrell, 2007; Forsyth et al., 2008). These Quaternary gravels are inferred to have been deposited mainly as outwash during glacial periods. The latest period of gravel aggradation is thought to have occurred during the Last Glacial Maximum (LGM) ( 28000 to 18000 years ago) and waned in response to glacial retreat in the upper reaches of the main river valleys (Alloway et al., 2007; Forsyth et al., 2008). Alluvial aggradation was followed by down-cutting of the main rivers and abandonment of the constructional surface (Cox and Barrell, 2007; Hornblow et al., 2014) (Figs. 2, 3). The surface rupture traces of active faults have, in some cases, been buried by LGM alluviation (e.g., Hornblow et al., 2014). In other cases, the presence of active faults has been identified by subtle folding on the LGM surface, drainage anomalies such as channel sinuosity and width variations, and asymmetrically distributed and/or deformed river terraces that record the emergence of fault propagation folds above thrust fault tips (e.g., Campbell et al., 2012).

The city of Christchurch is located primarily upon a low relief, low elevation (0-20 masl) alluvial landscape (Fig. 4). Much of the central and eastern city is built upon a progradational coastal sequence of alluvial silt and sand deposits, drained peat swamps and estuaries, sand of fixed to semi-fixed dunes, and underlying marine sands (collectively referred to as the Christchurch Formation). These formed as sea levels transgressed then regressed from a mid-Holocene highstand that reached inland $\sim 1 \mathrm{~km}$ west of the current position of the central business district (CBD) at $\sim 6.5$ thousand years before present (Fig. 2) (Brown et al., 1995). The Christchurch Formation is underlain by glacial-outwash gravels (Riccarton Formation) at depths of 20-40 m in the central and eastern city (Cubrinovski and McCahon, 2011). Quaternary alluvial deposits interfinger with estuarine and shallow marine deposits to depths of approximately $240 \mathrm{~m}$ under eastern Christchurch (Brown et al., 1995). The hillslope suburbs of southern Christchurch are situated on the Miocene volcanic rocks and shallow sandy bays of Banks Peninsula (Figs. 2, 4). The volcanic rocks are mantled by Quaternary loess and colluvially-reworked loess mixed with boulders; the loessic sequence where preserved is typically $>1 \mathrm{~m}$ thick and locally $>5 \mathrm{~m}$ thick (Bell and Trangmar, 1987). The geology of Christchurch is described in detail in Brown et al. (1995); Browne et al. (2012); Forsyth et al. (2008), and Begg et al. (2015).

In summary, the regional tectonic setting of the CES reflects the progressive interaction of the Pacific Plate with the eastern periphery of the Southern Alps orogen (e.g., Pettinga et al., 2001). The structural pattern of deformation is defined by the E-W trending, dextral strike-slip faults that overprint and reactivate an inherited network of Cretaceous to Neogene normal faults. These are in turn linked by segmented, NE trending thrust faults, expressed by growing asymmetric anticlines, blind to emerging thrusts and back-thrusts. This interacting relay of structures is accommodating the transpressional deformation in response to the regional, WNW-oriented, maximum horizontal compressional stress. The topographically variable modern landscape and heterogenous distribution of near-surface materials in the CES region reflects its setting on an active alluvial plain between a tectonically active mountain belt and a constantly changing coastline.

\subsection{Pre-CES historical seismicity}

Written accounts of felt earthquakes in Christchurch extend back to 1844 , when one of the early European settlers wrote that 'there was very little noise but a curious trembling feeling for a few seconds' (Deans, 1937). Earthquakes were also felt locally in 1851 , 1855, and 1868 (http://lostchristchurch.org.nz/a-history-of-quakes-inchristchurch). Two proximal, moderate-magnitude historical earthquakes caused damage to buildings and contents in the 19th Century; the $1869 \mathrm{M}_{\mathrm{w}}$ 4.7-4.9 Christchurch earthquake and $1870 \mathrm{M}_{\mathrm{w}}$ 5.6-5.8 Lake Ellesmere earthquake (Fig. 2). The former generated Modified Mercalli Intensity (MMI) shaking of up to MMI 7 (PGA 0.24 g; converted using Wald et al., 1999) in the Christchurch CBD and eastern suburbs and caused damage to unreinforced masonry. It was reported by the Weekly News (26 June 1869; cited by Downes and Yetton, 2012) that '[after the earthquake] the tide runs higher up the Heathcote River than formerly', indicating that this earthquake may have caused surface subsidence. The 1870 earthquake caused shaking up to MMI 6 (PGA $0.13 \mathrm{~g}$ ) and minor infrastructural damage in central and eastern Christchurch, Banks Peninsula, and South Canterbury. 'Tons of loose rockfall' were observed to fall from coastal cliffs on the southern side of Lyttelton harbour (The Christchurch Star, Sunday Sept. 3 1870), although the extent and severity of mass movements were not systematically documented. The lack of hypocentre spatial resolution precludes assignment of the 1869 and 1870 earthquakes to a source fault.

Regional earthquakes including the $1881 \mathrm{M}_{\mathrm{w}} \sim 6$ Castle Hill, 1888 $\mathrm{M}_{\mathrm{w}}$ 7.1-7.3 North Canterbury, $1901 \mathrm{M}_{\mathrm{w}} 6.9$ Cheviot, $1922 \mathrm{M}_{\mathrm{w}} 6.4$ Motunau, and $1929 \mathrm{M}_{\mathrm{w}}$ 7.1 Arthur's Pass earthquakes all caused $\mathrm{MMI} \geq 6$ shaking and damage to stone and unreinforced masonry structures in Christchurch (Fig. 2A) (Pettinga et al., 2001; Cowan, 1991). No ground surface manifestation of liquefaction or extensive severe rockfall were reported in Christchurch from these events, although in the 1888 earthquake "on the Sumner Road, near Lyttelton, blocks of rocks 10 tons in weight gave way, and went into the harbour with a great crash, carrying fences and other obstructions before them' (New Zealand Herald, Volume XXV, Issue 9149, 3 September 1888, Page 3). The 1901 Cheviot earthquake caused ground surface manifestation of liquefaction in Kaiapoi (Fig. 2) (Berrill et al., 1994). A $\mathrm{M}_{\mathrm{L}} 5.0$ earthquake occurred in the vicinity of the Greendale Fault in 1968 (Fig. 2), but no damage was reported. The lack of spatial resolution of epicentre location precludes reliable assignment of this earthquake to the Greendale Fault. A clustered sequence of earthquakes beginning with the $1994 \mathrm{M}_{\mathrm{w}} 6.7$ Arthurs Pass earthquake and including the $1994 \mathrm{M}_{\mathrm{w}} 6.0,1995 \mathrm{M}_{\mathrm{w}} 6.0$, and $1995 \mathrm{M}_{\mathrm{w}} 6.2$ Cass earthquakes occurred with epicentres $<40 \mathrm{~km}$ apart in the eastern Southern Alps (Fig. 2A) (Gledhill et al., 2000; Robinson and McGinty, 2000) and generated up to MMI $\sim 5$ in Christchurch (Pettinga et al., 2001). 
Regional seismicity in the 70 years preceding the CES exhibited G-R frequency magnitude scaling behaviour, with a 'b value' $\approx 1$, and included three $M_{L} \geq 5$ and $30 M_{L} \geq 4$ events (Fig. 5). Although the seismic catalogue is variably incomplete for $\mathrm{M}_{\mathrm{L}} \leq 4$ earthquakes prior to 1964 , it is unlikely that any $\mathrm{M}_{\mathrm{L}} \geq 5$ events are missing for this time period. Recurrence intervals of $M_{L} 6$ and 7 earthquakes derived from extrapolation of the G-R relationship are $\sim 200 \mathrm{yr}$ and $\sim 1800 \mathrm{yr}$, respectively, for the specified region. Pre-CES PGA estimates for shallow 'site class C' soil profiles with site period $\mathrm{T} \leq 0.6 \mathrm{~s}$ for Christchurch were $0.11 \mathrm{~g}$ for $50 \mathrm{yr}$ recurrence interval and $0.22 \mathrm{~g}$ for $200 \mathrm{yr}$ recurrence interval (Stirling et al., 2008). Prior to the CES, the 475-year PGA hazard for Christchurch of $\sim 0.3 \mathrm{~g}$ (Stirling et al., 2008) was dominated by distributed seismicity ( $\mathrm{M}_{\mathrm{w}}$ 5-6.8 at distances of less than $50 \mathrm{~km}$ ) with further significant contributions from mapped regional fault systems capable of $\mathrm{M}_{\mathrm{w}} \geq 7.0$ earthquakes.

\section{Seismology of the CES}

\subsection{Introduction}

The majority of large CES epicentres $\left(\mathrm{M}_{\mathrm{w}}>5\right)$ were situated within $10 \mathrm{~km}$ of the Christchurch CBD (Fig. 3). A national state of emergency was declared following both the $\mathrm{M}_{\mathrm{w}}$ 7.1 Darfield earthquake and 22 February $2011 \mathrm{M}_{\mathrm{w}} 6.2$ Christchurch earthquake (henceforth $\mathrm{M}_{\mathrm{w}} 6.2$ Christchurch earthquake) (Berryman, 2012) and parts of the Christchurch CBD were cordoned off from the public for more than two years following the $M_{w} 6.2$ Christchurch earthquake. The $M_{w} 6.2$ Christchurch earthquake caused 185 fatalities, 133 of whom died in two building collapses in the CBD, five of whom died from rockfalls in the Port Hills in southern Christchurch, and 47 of whom died from falling debris from damaged buildings throughout the city (http:// www.police.govt.nz/major-events/previous-major-events/christchurchearthquake/list-deceased\#other). The most recent estimate of direct costs due to CES earthquake damage (as of July 2015) is NZ\$ $40 \mathrm{~B}$ ( US\$ 31 B) (http://www.nbr.co.nz/article/christchurch-quake-costrises-10b-40b-bd-139278). Land and infrastructure damage due to liquefaction resulted in a central government buyout of more than 7400 residential properties in eastern Christchurch at an estimated cost of over NZ $\$ 2.8$ billion. Liquefaction affected $\sim 51000$ residential properties and damaged $\sim 15,000$ residential houses beyond economic repair. A further 714 residential properties in the Port Hills (Fig. 1) were purchased by central government due to cliff collapse and/or boulder roll life safety risk (http://cera.govt.nz/port-hills/red-zone).

\subsection{Seismic sources}

The CES initiated with the $\mathrm{M}_{\mathrm{w}}$ 7.1 Darfield earthquake with an epicentre located approximately $44 \mathrm{~km}$ west of the Christchurch CBD (Gledhill et al., 2011) (Fig. 3). The earthquake involved the complex rupture of 6-7 faults with different orientations, kinematics, and slip distributions (Beavan et al., 2012). The predominant moment release occurred from the rupture of three segments of the Greendale Fault (Beavan et al., 2010, 2012; Quigley et al., 2010b, 2012). The Greendale Fault rupture produced complex near-fault ground motion and strong directivity towards Christchurch (Bradley, 2012a, 2012b). Seismic source models (Beavan et al., 2010, 2012; Holden et al., 2011; Elliott
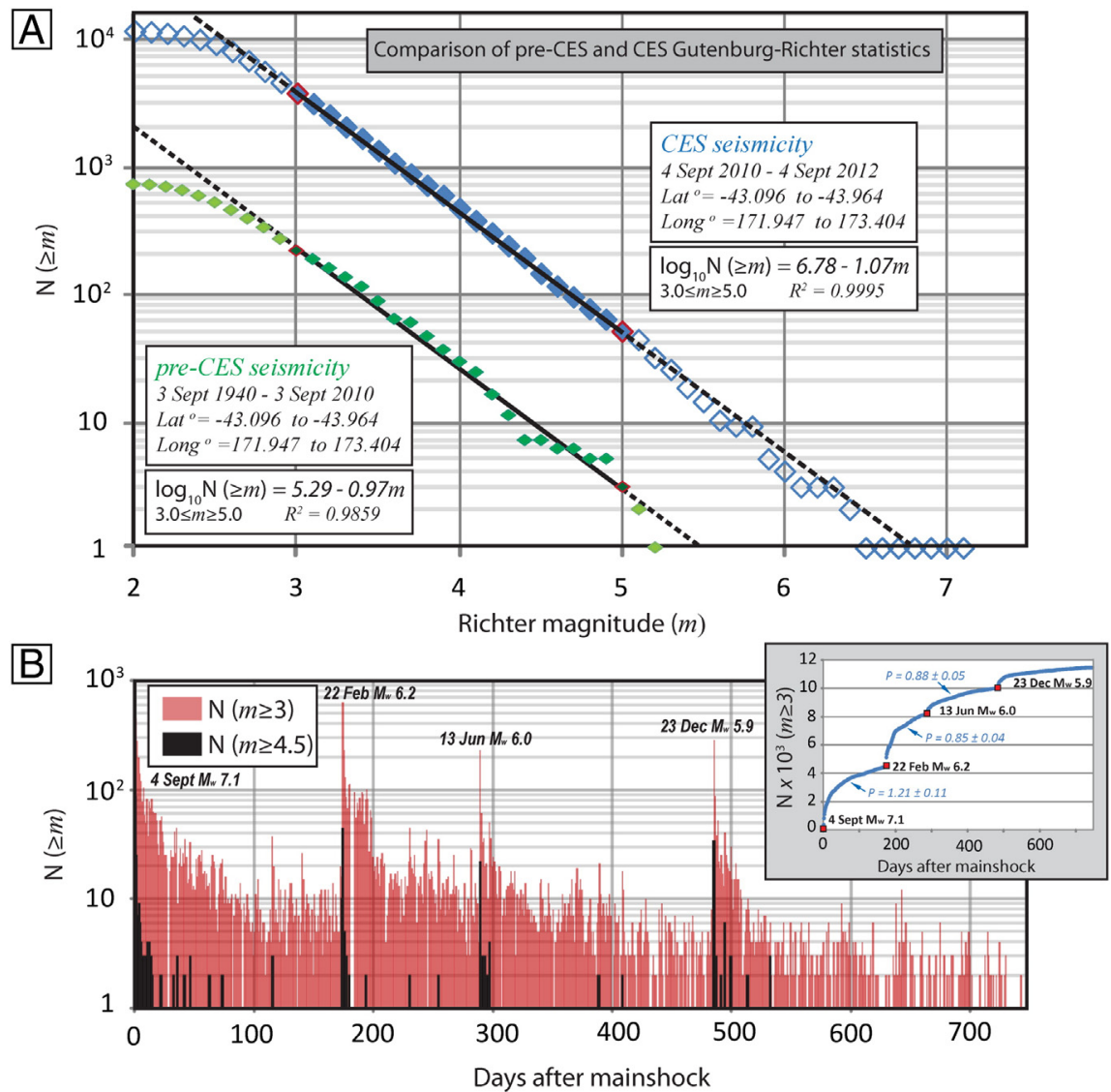

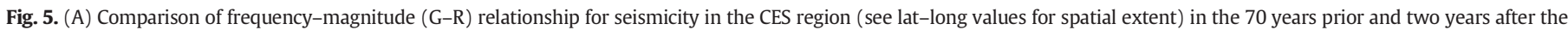

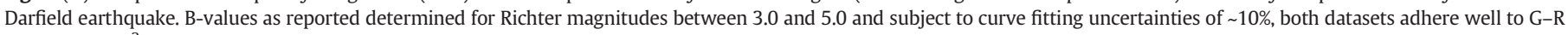

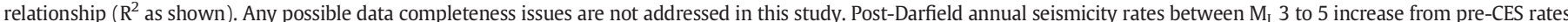

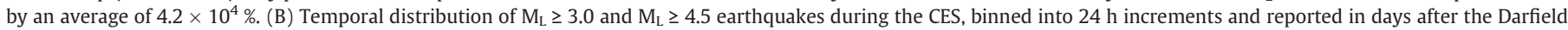

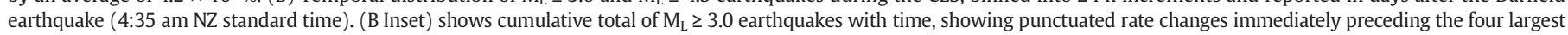
CES earthquakes, in accordance with Omori's Law. P-values describing seismicity decay rate exponent from Shcherbakov et al. (2012). All seismic data from www.geonet.org.nz. 
et al., 2012; Atzori et al., 2012) provide varying interpretations of fault segmentation, fault slip, and $\mathrm{M}_{\mathrm{w}}$ sourced from different faults. Fig. 3 shows $\mathrm{M}_{\mathrm{w}}$ estimates for individual faults in the CES (from Beavan et al., 2012). Maximum subsurface slip on the Greendale Fault occurred at depths of 2 to $6 \mathrm{~km}$ (Beavan et al., 2012) and may have exceeded $7 \mathrm{~m}$ over a strike length of $\sim 7-8 \mathrm{~km}$ (Elliott et al., 2012). The inferred upper limits of rupture of the blind faults range from 0.5 to $1 \mathrm{~km}$ depth (Beavan et al., 2012). Static stress drop estimates for individual faults range from $13.9 \pm 3.7 \mathrm{MPa}$ (Greendale Fault + Greendale Fault West + Greendale Fault East; Quigley et al., 2012) to 6-11 MPa (Elliott et al., 2012), consistent with static stress drops from earthquakes in similar active tectonic settings peripheral to plate boundaries (e.g., 7$12 \mathrm{MPa}$ in Landers-Hector Mine earthquake sequence; Price and Bürgmann, 2002). Fry and Gerstenberger (2011) estimated an apparent stress drop of $16 \mathrm{MPa}$ for the $\mathrm{M}_{\mathrm{w}}$ 7.1 Darfield earthquake. Global centroid moment tensor (CMT; www.globalcmt.org; accessed April 2012), Geonet regional moment tensor (RMT; www.geonet.org; accessed April 2012), and geodetic moment tensor (Beavan et al., 2012) solutions and $\mathrm{M}_{\mathrm{w}}$ estimates vary for the Darfield earthquake (Fig. 3). $\mathrm{M}_{\mathrm{w}}=7.1 \pm$ 0.1 includes most estimates. Slip in the Darfield earthquake and aftershocks is consistent with a horizontal $\sigma_{1}$ oriented $\sim \mathrm{N} 115^{\circ} \mathrm{E}$ (Fig. $2 \mathrm{~B}$ ) and horizontal $\sigma_{3}$. Most aftershocks had nearly the same P-axis orientation as the mainshock, implying that there were no significant changes in stress orientations throughout the CES (Herman et al., 2014).

The $M_{w} 6.2$ Christchurch earthquake involved the rupture of 2-3 blind faults (Port Hills Faults 1-3; Fig. 3) with reverse and right-lateral displacements (Beavan et al., 2012). The rupture is inferred to have extended to within $\sim 0.5$ to $1 \mathrm{~km}$ depth below the surface, suggesting rupture termination in Miocene volcanic or underlying sedimentary rocks. Maximum coseismic slip was 2.5 to $3 \mathrm{~m}$ at depths of 4 to $6 \mathrm{~km}$ (Beavan et al., 2012; Elliott et al., 2012). The 13 June $2011 \mathrm{M}_{\mathrm{w}} 6.0$ earthquake (forthwith $\mathrm{M}_{\mathrm{w}}$ 6.0 Christchurch earthquake) likely involved intersecting ENE-striking, reverse-right lateral and antithetic, NWstriking left-lateral faults (Port Hills Faults 4, 5; Fig. 3) that are inferred to have ruptured to within $1 \mathrm{~km}$ of the surface, with maximum subsurface slip of $<1 \mathrm{~m}$ (Beavan et al., 2012) (Fig. 3).

The 23 December $2011 \mathrm{M}_{\mathrm{w}} 5.8$ and $\mathrm{M}_{\mathrm{w}} 5.9$ earthquakes (forthwith December $\mathrm{M}_{\mathrm{w}} 5.8$ and 5.9 earthquakes) ruptured two, largely offshore, NE-striking, reverse-right-lateral, blind faults within one-hour twenty minutes of each other (Pegasus Bay Faults 1, 2; Fig. 3); maximum slip of $>1.4 \mathrm{~m}$ occurred at depths of $2-5 \mathrm{~km}$ and ruptures extended up-dip to $\sim 1 \mathrm{~km}$ depth (Beavan et al., 2012)(Fig. 3). Aftershock relocations carried out using double-difference tomography show a well-defined, NNE-SSW to NE-SW series of earthquakes, with most of the activity occurring at depths $>5 \mathrm{~km}$ and an average depth of $\sim 10 \mathrm{~km}$ (Ristau et al., 2013). Regional moment tensor solutions indicate that the vast majority (45 of 53 events) are reverse-faulting events with an average P-axis azimuth of $125^{\circ}$. Strong-motion data inversion favours a SEdipping fault plane for the largest event $\left(M_{w} 5.9\right)$ with a slip patch of $18 \mathrm{~km}$ long $\times 15 \mathrm{~km}$ wide and a maximum slip of $0.8 \mathrm{~m}$ at $3.5 \mathrm{~km}$ depth.

Additional CES seismic source studies pertaining to issues not described in detail here include Bradley et al. (2014), Li et al. (2014), Holden et al. (2011), Oth and Kaiser (2014), Herman et al. (2014), Syracuse et al. (2012, 2013), Holt et al. (2013).

\subsection{Characteristics of the CES aftershock sequence}

Between September 2010 and September 2012, the CES had 45 $M_{L} \geq 5.0$ and $3 M_{L} \geq 6.0$ aftershocks (Figs. 3, 5), or $12 M_{w} \geq 5.0$ and 3 $M_{w} \geq 6.0$ events (Table 1 ). The post-Darfield earthquake CES events including the $\mathrm{M}_{\mathrm{w}} \geq 5.0$ events were classified as 'aftershocks' because (i) they were smaller in magnitude than the $M_{w} 7.1$ Darfield mainshock, (ii) they occurred in close temporal succession to the mainshock (i.e. within seconds to months), and (iii) they followed classical G-R scaling aftershock frequency-magnitude distributions, modified Omori's law aftershock decay rates (Fig. 5B), and a modified version of Bath's law for the largest magnitude aftershock (Shcherbakov et al., 2012), and (iv) they occurred primarily in areas of modelled increases in Coulomb (static) stress changes due to the mainshock (e.g., Steacy et al., 2013), although the correlation between cumulative aftershock activity and positive static stress lobes has been debated (Bebbington et al., 2015). The sequence was highly 'clustered' in the sense that the postmainshock (2010-2012) average annual earthquake seismicity rate for $\mathrm{M}_{\mathrm{w}}$ 3-5 earthquakes was $\sim 500$ times as great as the average premainshock (1940-2010) annual seismicity rate for the same spatial domain (Fig. 5A). Earthquake decay rates consistent with modified Omori law behaviour were also observed following the largest aftershocks in the sequence (Fig. 5B inset) (Shcherbakov et al., 2012; Gerstenberger et al., 2014).

The spatial-temporal evolution of CES seismicity (Fig. 3) has been studied by Bannister and Gledhill (2012). Early aftershocks were particularly concentrated at the eastern end of the Greendale Fault, although all of the causative faults for the $\mathrm{M}_{\mathrm{w}}$ 7.1 Darfield earthquake had some aftershock activity (Fig. 3). One of the largest early aftershocks $\left(\mathrm{M}_{\mathrm{L}}\right.$ 5.0; 8 Sept. 2010) occurred in close proximity to the hypocenter of the $\mathrm{M}_{\mathrm{w}} 6.2$ Christchurch earthquake. A $\mathrm{M}_{\mathrm{w}} 4.7$ aftershock on 26 Dec. 2010 (Boxing Day aftershock, Table 1), located on a steeply dipping blind fault beneath central Christchurch, caused vertical PGAs locally exceeding $0.5 \mathrm{~g}$ and caused some damage in Christchurch's CBD. The $M_{w} 6.2$ Christchurch earthquake was the largest of successive $M_{L} 6.3$, 5.8 , and 5.9 earthquakes and numerous aftershocks, spread over two hours (Table 1 ); subsequent aftershocks were largely concentrated in the vicinity of the $M_{w} 6.2$ source faults (e.g., Port Hills Faults 1-3; Fig. 3) and in the area between these and the eastern tip of the Greendale Fault. The $\mathrm{M}_{\mathrm{w}} 6.0\left(\mathrm{M}_{\mathrm{L}}\right.$ 6.4) Christchurch earthquake on 13 June 2011 was preceded 1 h 20 min earlier by a $M_{L} 5.6$ earthquake; these events and related aftershocks were located primarily in southeast Christchurch along a NNW-trending alignment, although some large aftershocks (e.g., 21 June $2011 \mathrm{M}_{\mathrm{L}}$ 5.4; Table 1) continued to occur in the gap between the Port Hills and Greendale Faults. Following the 23 December $2011 \mathrm{M}_{\mathrm{w}} 5.8$ and 5.9 earthquakes $\left(\mathrm{M}_{\mathrm{L}} 5.8\right.$ and 6.0 within $1 \mathrm{~h} 20 \mathrm{~min}$ ), aftershocks shifted primarily to a NE-striking alignment offshore of Christchurch in Pegasus Bay. The CES displayed an overall pattern of eastward-propagating seismic activity with concentrations closely tracking the geometry of orientation of the fault sources of the major (i.e. $M_{L} \geq 5.5$ ) earthquakes (Fig. 3). Reyners et al. (2014) attributed some aspects of the CES seismicity to widespread crustal cracking influenced by the presence of a thickened oceanic plateau (Hikurangi Plateau, Fig. 2) and the anomalously deep brittle-ductile transition beneath the CES source faults.

\subsection{Ground motion aspects of the CES}

\subsubsection{Summary of observations}

A high density of strong ground motion instruments in the Canterbury region (Fig. 4B) resulted in a wealth of well-recorded CES earthquake-induced ground motions, including many near-fault ground motions (Bradley, 2012b; Bradley and Cubrinovski, 2011a; Bradley et al., 2014). Prior to the CES there was a paucity of high amplitude recorded strong ground motions in New Zealand, primarily as a result of a sparse instrumentation network before the commencement of GeoNet in 2001 (www.geonet.org.nz). Prior to 2009, the maximum PGA recorded in New Zealand was $0.39 \mathrm{~g}$, with only 7 observed ground motions exceeding $0.2 \mathrm{~g}$ PGA (Bradley and Cubrinovski, 2011a). During the CES, horizontal ground motions of up to $1.51 \mathrm{~g}$ PGA were recorded, with over 20 ground motions exceeding $0.4 \mathrm{~g}$ PGA and over 80 ground motions exceeding 0.2 g PGA (Bradley et al., 2014).

Fig. 6 illustrates the ground motions recorded for the $M_{w} 7.1$ Darfield, $\mathrm{M}_{\mathrm{w}} 6.2$ and 6.0 Christchurch, and $\mathrm{M}_{\mathrm{w}} 5.9$ and 5.8 December earthquakes, which were the largest earthquakes of the CES. These data are shown in terms of the spatial distribution of PGA 


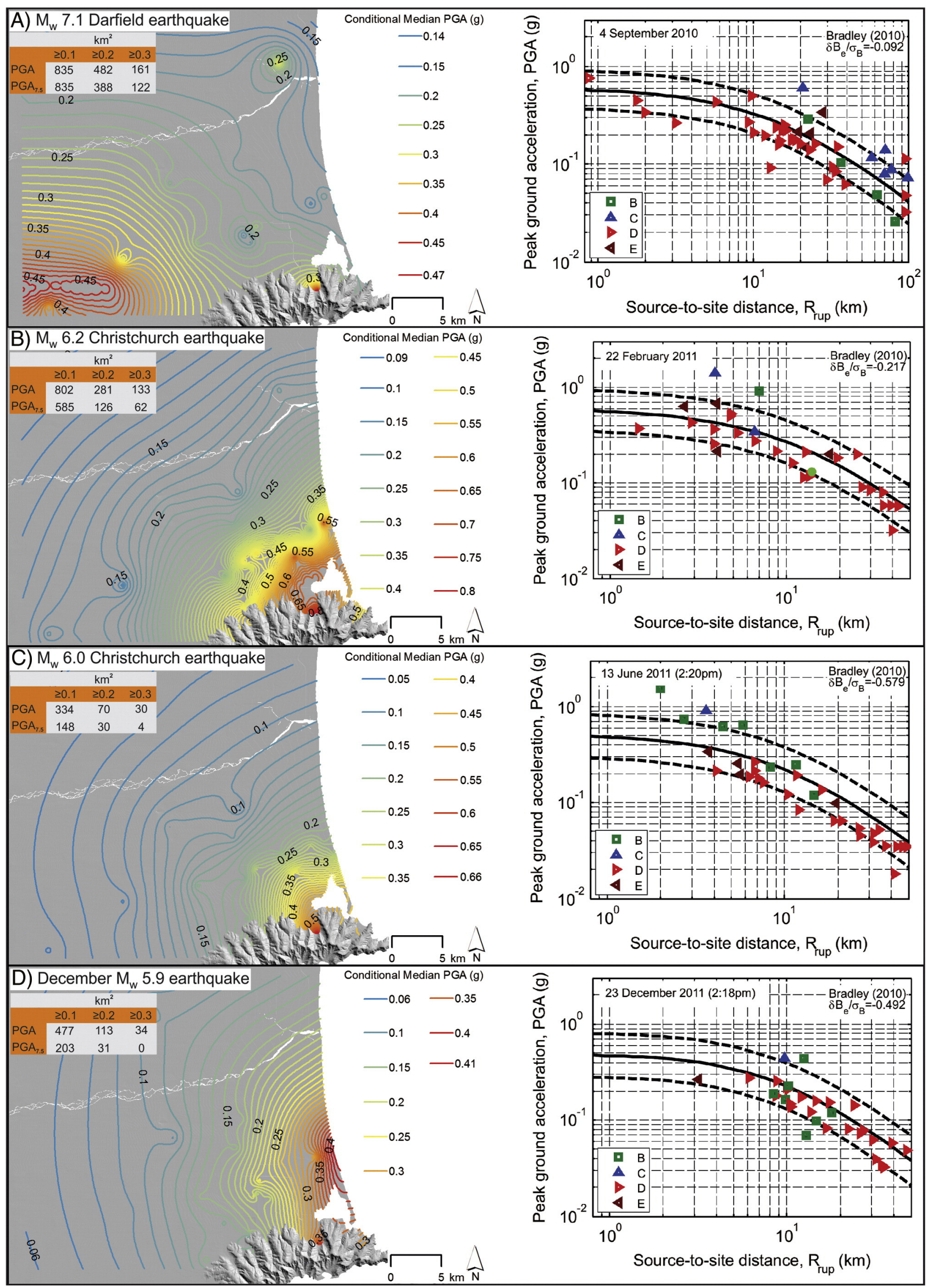


over the region and the specific PGA values recorded at strong motion stations in comparison to New Zealand-specific empirical ground motion predictions (Bradley, 2010, 2013a). Because of the proximity of the $\mathrm{M}_{\mathrm{w}} 6.2$ Christchurch earthquake to Christchurch, it produced the strongest ground motion shaking over the urban Christchurch city region (Fig. 6). The largest instrumental PGAs were $1.51 \mathrm{~g}$ (horizontal PGA observed at Godley Head station (GODS; Fig. 2B) during the $\mathrm{M}_{\mathrm{w}} 6.0$ June earthquake horizontal PGA), $2.21 \mathrm{~g}$ (vertical PGA observed at Heathcote Valley (HVSC) station during the $\mathrm{M}_{\mathrm{w}}$ 6.2 Christchurch earthquake). The largest PGV was $115 \mathrm{~cm} \mathrm{~s}^{-1}$ (PGV observed at Greendale (GDLC; Fig. 2B) during the $M_{w}$ 7.1 Darfield earthquake).

Areal extents of PGA $\geq 0.1,0.2$, and $0.3 \mathrm{~g}$ within the Christchurch area are shown for the four largest events in Fig. 6. Collectively these reveal the importance of source location in addition to $\mathrm{M}_{\mathrm{w}}$ and other factors (Fig. 1) when considering ground motion histories for a specific study area. For example, the $\geq 0.1 \mathrm{~g}$ and $\geq 0.3 \mathrm{~g}$ areas of Fig. 6 extent were similar for the $\mathrm{M}_{\mathrm{w}}$ 7.1 Darfield and $\mathrm{M}_{\mathrm{w}}$ 6.2 Christchurch earthquakes despite the significant difference in $\mathrm{M}_{\mathrm{w}}$ between these events. Moment magnitude-weighted PGAs $\left(\mathrm{PGA}_{7.5}\right.$ ) are also shown (for thorough descriptions of the derivation of $\mathrm{M}_{\mathrm{w}}$ weighting of PGAs to account for shaking duration, and applications to liquefaction analysis, see Youd et al., 2001; Arango, 1996; Cetin and Bilge, 2011; and references therein). Total terrestrial areas for the $\geq 0.1,0.2,0.3 \mathrm{~g}$ contours are shown in Table 1. In most cases, estimated terrestrial areas based on projection of PGA contours are $~ 60-80 \%$ those of predicted areas estimated from Ground Motion Prediction Equations (GMPEs) and source fault locations and dimensions (see Section 6.1 below) because a significant areal extent of strong shaking occurred offshore in Pegasus Bay, particularly for earthquakes with submarine or near-coast source fault locations (Figs. 3, 6).

\subsubsection{Comparison of empirical predictions}

The large recorded strong ground motions can be attributed to the high instrument density in the immediate near-fault region, and not necessarily as a result of any particularly anomalous aspect of the earthquake source. The four largest $\mathrm{M}_{\mathrm{w}}$ earthquakes produced ground motions that are broadly consistent with the NZ-specific GMPE (Fig. 6). Despite this general agreement, significant scatter exists in the amplitude of the observations for approximately similar source-to-site distances. This scatter can be attributed to the complexity in the features of the earthquake source, wave propagation path, and local site effects, all of which are poorly represented solely by the earthquake magnitude, and may be an indicator of the soil classification (Fig. 1). Bradley (2015) examined the differences between observations and empirical predictions across the 10 most significant events in the CES to statistically quantify if there were any systematic deviations of the observed ground motions from empirical predictions. No overall bias of ground motion amplitudes at short vibration periods (e.g. PGA as shown in Fig. 6) was observed; however, an increasing under-prediction of response spectral amplitudes with increasing vibration period was observed, as a result of basin-generated surface waves, and to a lesser extent the influence of non-linear site response at moderate vibration periods ( $\mathrm{T}=0.5-2.0 \mathrm{~s}$ ) was shown. The overall, unbiased prediction of short period ground motion amplitudes (e.g. PGA) is consistent with estimates of mean Brune stress drop of $5 \mathrm{MPa}$ for CES earthquakes (Oth and Kaiser, 2014); this is equivalent to values of 50 bar typically utilised for Coastal California (Graves and Pitarka, 2010), the region on which the Bradley NZ-specific model is based (Bradley, 2010, 2013a, 2013b). Systematic departures from the empirical prediction at specific ground motion stations over multiple events are attributed to wave propagation or local site effects (Bradley, 2015) that are elaborated upon in the next section.

\subsubsection{Specific strong motion features observed}

4.4.3.1. Forward directivity. A near-source effect of particular seismological interest is forward directivity, which results from the alignment of the rupture front, direction of slip, and source-to-site direction. The manifestation of forward directivity is the arrival of a large portion of the radiated seismic energy in a single pulse at the beginning of the ground motion record. This seismic energy is oriented in the direction normal to the fault strike, and has a particularly large damage potential due to its large amplitude and short duration. Forward-directivity effects occur in the near source region in earthquakes of all magnitudes (Boatwright, 2007), and their significance increases with increasing earthquake magnitude (due to longer rupture duration). Forward directivity effects were particularly significant for the $M_{w}$ 7.1 Darfield earthquake as a result of its large $M_{w}$, strike-slip faulting mechanism and rupture propagation of the central and eastern section of the Greendale Fault towards Christchurch (Bradley, 2012a; Holden et al., 2011). Forward directivity was the dominant phenomena that resulted in the large PGV recorded at the GDLC station (Table 1). In contrast, forward directivity effects from the $M_{w} 6.2$ Christchurch earthquake were less significant when compared to the $M_{w}$ 7.1 Darfield earthquake due to the smaller $M_{w}$ of the former. Directivity effects for this event are prevalent only in a smaller area in the eastern suburbs of Christchurch as a result of the misalignment between the direction of slip on the fault and the inferred direction of rupture propagation on the fault (Aagaard et al., 2004; Bradley and Cubrinovski, 2011a, 2011b; Holden, 2011).

4.4.3.2. Basin-generated surface waves. The location of southern Christchurch on a shallow tapering wedge of Quaternary sediments overlying the volcanic bedrock of Banks Peninsula (Forsyth et al., 2008) caused an amplification in long-period ground motion due to basin-generated surface waves. Numerous sites observed during the $\mathrm{M}_{\mathrm{w}}$ 7.1 Darfield and $M_{w} 6.2$ Christchurch earthquakes experienced significant, long period ground motion that is attributable to surface wave generation, in addition to the large amplitude, long period ground motion resulting from forward directivity. These basin-induced surface waves were the principal reason for the systematic under-prediction of long period ground motions in the CES (Bradley, 2015).

4.4.3.3. Strong vertical ground motions. Large ground motion amplitudes were observed in the vertical component at various locations in both the $M_{w}$ 7.1 Darfield and $M_{w} 6.2$ Christchurch earthquakes, particularly the latter. Large vertical accelerations occurred because the majority of strong motion stations are located on soft Holocene sediments; large vertical accelerations at near-source soil sites can result from the conversion of inclined SV-waves to P-waves at the sedimentary basin interface. The P-waves are subsequently amplified and refracted towards vertical incidence due to the basin P-wave velocity gradient (Silva, 1997). That is, large vertical accelerations at near-source locations are expected, and are not an indication on their own of any peculiarities associated with the earthquake source.

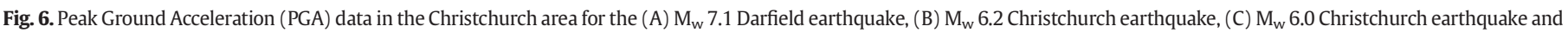

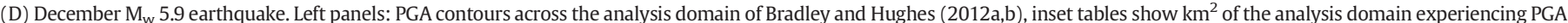

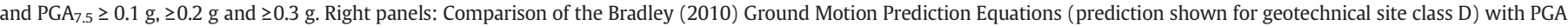

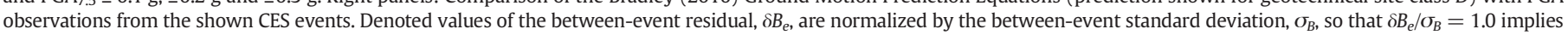
observations with a between-event residual which is one standard deviation above zero. From Bradley (2014). 

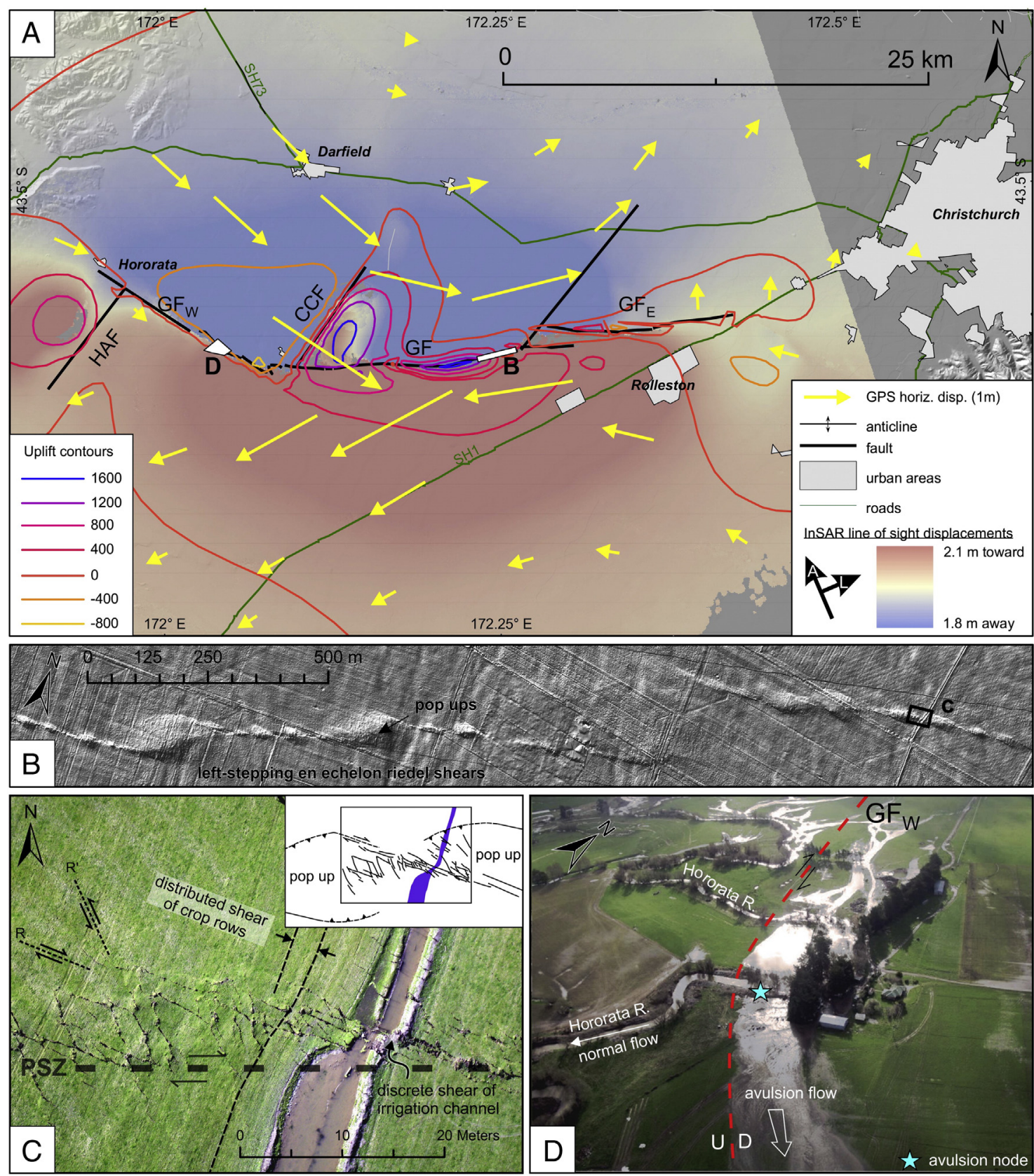

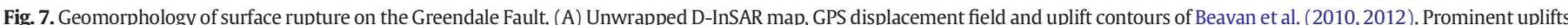

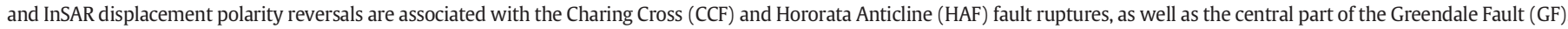

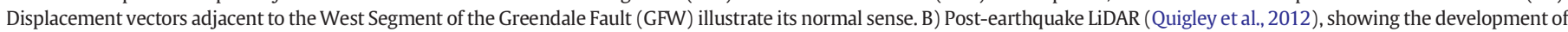

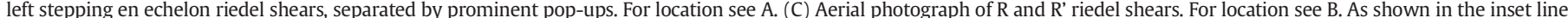

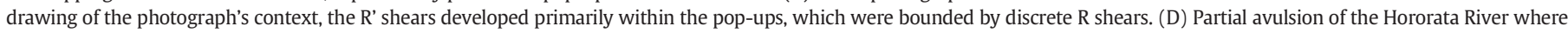
the top-to-the-NE, dextral oblique normal West Segment of the Greendale Fault crossed a meander in the Hororata River. Note the extensive flooding upstream of the avulsion node.

\section{CES Environmental effects, seismologic thresholds, and palaeoseismic implications}

\subsection{Surface rupture}

\subsubsection{Effects and distribution}

Surface rupture during the $\mathrm{M}_{\mathrm{w}}$ 7.1 Darfield earthquake was restricted to three segments of the Greendale Fault (GF, GFW, GFE; Figs. 3, 7) that were distinguished by fault orientation and subsurface geometry (Beavan et al., 2012; Quigley et al., 2010b, 2010c, 2012; Van Dissen et al., 2011; Barrell et al., 2011; Villamor et al., 2012; Duffy et al., 2013). Surface rupturing consisted of discrete surface fracturing, broad wavelength surface folding, and formation of topographic bulges (i.e. pop-ups) with surface areal extents of $<10$ to $>1000 \mathrm{~m}^{2}$ and amplitudes locally exceeding $1 \mathrm{~m}$ (Fig. 7B, C). Right-lateral normal (NE-side-down) monoclinal flexure occurred on the western segment over a length of $\sim 4.5 \mathrm{~km}$, equivalent to $\sim 30 \%$ of the segment's subsurface rupture length. Right-lateral displacement (with a small vertical component of S-sideup) surface rupturing occurred on the central segment for $\sim 19 \mathrm{~km}$, equivalent to $100 \%$ of the segment's subsurface rupture length. A structurally complex surface rupture deformation zone, including small restraining steps and pop-ups, was mapped in the releasing bend between the western and central fault segments (Duffy et al., 2013). The total combined surface rupture length for the Greendale Fault segments was $29.5 \pm 0.5 \mathrm{~km}$ (Van Dissen et al., 2011; Quigley et al., 2012). The step-over area between the central (GF) and eastern $\left(\mathrm{GF}_{\mathrm{E}}\right)$ 
Table 2A

Earthquake-induced environmental phenomena, associated seismologic thresholds for phenomenon initiation, and likely preservation potential in geologic record.

\begin{tabular}{|c|c|c|c|c|c|c|c|c|c|}
\hline $\begin{array}{l}\text { Earthquake } \\
\text { faulting-induced } \\
\text { phenomenon }\end{array}$ & $\begin{array}{l}\text { Seismic origin of } \\
\text { phenomenon }\end{array}$ & $\begin{array}{l}\text { Temporal nature } \\
\text { of phenomenon }\end{array}$ & $\begin{array}{l}\text { Minimum } \\
\text { threshold } \\
\mathrm{M}_{\mathrm{w}} \text { in CES }\end{array}$ & $\begin{array}{l}\text { Preservation potential in } \\
\text { stratigraphic record }\end{array}$ & $\begin{array}{l}\text { Preservation potential } \\
\text { at surface }\end{array}$ & $\begin{array}{l}\text { Preservation potential in } \\
\text { biologic, geochemical, or } \\
\text { hydrologic record }\end{array}$ & $\begin{array}{l}\text { 'Palaeo' features } \\
\text { attributable to } \\
\text { palaeo-earthquakes } \\
\text { identified? }\end{array}$ & $\begin{array}{l}\text { Uniquely diagnostic } \\
\text { of seismic origin? }\end{array}$ & $\begin{array}{l}\text { ESI-2007 } \\
\text { metric } \\
\text { (range } \\
\text { of max) }\end{array}$ \\
\hline $\begin{array}{l}\text { 1. Fault surface } \\
\text { rupture and } \\
\text { related } \\
\text { deformation }\end{array}$ & $\begin{array}{l}\text { Coseismic fault } \\
\text { propagation to } \\
\text { surface }\end{array}$ & $\begin{array}{l}\text { Coseismic and } \\
\text { permanent }\end{array}$ & $6.6 \pm 0.1^{x}$ & $\begin{array}{l}\text { High. Offset channels present } \\
\text { in shallow subsurface and } \\
\text { faulting identifiable at }>1-10^{4} \\
\mathrm{~m} \text { depth with geophysical and } \\
\text { seismological techniques }\end{array}$ & $\begin{array}{l}\text { High, but likely to } \\
\text { reduce in spatial extent } \\
\text { due to scarp erosion } \\
\text { and/or burial }\end{array}$ & $\begin{array}{l}\text { Possible record in } \\
\text { faulting-damaged trees }\end{array}$ & $\begin{array}{l}\text { Yes, penultimate } \\
\text { rupture identified in } \\
\text { shallow subsurface }\end{array}$ & Yes & XI \\
\hline $\begin{array}{l}\text { 2. Surface } \\
\text { deformation } \\
\text { above blind } \\
\text { fault }\end{array}$ & $\begin{array}{l}\text { Lateral or vertical } \\
\text { surface deformation } \\
\text { due to underlying } \\
\text { fault displacement }\end{array}$ & $\begin{array}{l}\text { Coseismic and } \\
\text { permanent }\end{array}$ & $6.2 \pm 0.1^{y}$ & $\begin{array}{l}\text { High, but challenging to } \\
\text { recognise for individual events } \\
\text { due to low amplitude and } \\
\text { broad wavelength of folding } \\
\text { and lack of discrete fracturing. } \\
\text { Folding identifiable at } \\
>1-1000 \text { m depth with } \\
\text { geophysical and seismological } \\
\text { techniques }\end{array}$ & $\begin{array}{l}\text { High, but likely to } \\
\text { reduce in spatial extent } \\
\text { due to erosion and/or } \\
\text { burial and challenging } \\
\text { to recognise from field } \\
\text { observations alone }\end{array}$ & $\begin{array}{l}\text { Possible changes in floral and } \\
\text { faunal coastal distributions } \\
\text { due to uplift or subsidence }\end{array}$ & $\begin{array}{l}\text { Yes, pre-CES folding } \\
\text { identified in deeper } \\
\text { stratigraphic layers }\end{array}$ & Yes & VII-IX \\
\hline $\begin{array}{l}\text { 3. River avulsion } \\
\text { and gradient } \\
\text { changes }\end{array}$ & $\begin{array}{l}\text { Partial or complete } \\
\text { avulsion of active } \\
\text { river channel due to } \\
\text { surface faulting } \\
\text { and/or folding }\end{array}$ & $\begin{array}{l}\text { Coseismic to } \\
\text { post-seismic and } \\
\text { permanent to } \\
\text { temporary }\end{array}$ & $6.4 \pm 0.2^{z}$ & $\begin{array}{l}\text { Moderate, requires } \\
\text { sedimentation or erosion in } \\
\text { avulsed channel }\end{array}$ & $\begin{array}{l}\text { High, although avulsion } \\
\text { may occupy formerly } \\
\text { occupied channel }\end{array}$ & LOW & $\begin{array}{l}\text { No, abundant } \\
\text { palaeochannels } \\
\text { identified, but } \\
\text { relationship to } \\
\text { seismicity unknown }\end{array}$ & $\begin{array}{l}\text { No, avulsion also commonly } \\
\text { generated by flooding, stream } \\
\text { capture, sediment flux } \\
\text { variability, etc. }\end{array}$ & IV-XI \\
\hline $\begin{array}{l}\text { 4. Forest } \\
\text { disturbance }\end{array}$ & $\begin{array}{l}\text { Fault rupture of } \\
\text { trees, roots and } \\
\text { supporting } \\
\text { substrate. Toppling } \\
\text { of trees in fault } \\
\text { damage zone. }\end{array}$ & $\begin{array}{l}\text { Coseismic to } \\
\text { postseismic and } \\
\text { permanent to } \\
\text { recoverable }\end{array}$ & $6.2 \pm 0.1$ & $\begin{array}{l}\text { possible, if fault-damaged } \\
\text { trees and roots are preserved } \\
\text { at surface and/or incorporated } \\
\text { into sedimentary record }\end{array}$ & $\begin{array}{l}\text { moderate, if } \\
\text { fault-damaged trees } \\
\text { remain in surface } \\
\text { environment and/or } \\
\text { leave geomorphic } \\
\text { signal of disturbance } \\
\text { (e.g. depressions } \\
\text { resulting from } \\
\text { uprooting) }\end{array}$ & $\begin{array}{l}\text { moderate, if fault-damaged } \\
\text { trees preserve evidence for } \\
\text { faulting disturbance and/or if } \\
\text { new tree cohorts colonise fault } \\
\text { scarp }\end{array}$ & $\begin{array}{l}\text { NO, trees are too young } \\
\text { to record penultimate } \\
\text { event }\end{array}$ & $\begin{array}{l}\text { no, tree disturbance also } \\
\text { common due to climatic } \\
\text { variations, weather extremes } \\
\text { (e.g., high winds) }\end{array}$ & VII-XI \\
\hline $\begin{array}{l}\text { 5. Coastal } \\
\text { tectonic uplift } \\
\text { or subsidence }\end{array}$ & $\begin{array}{l}\text { Faulting-induced } \\
\text { changes in vertical } \\
\text { position of coast } \\
\text { relative to sea-level }\end{array}$ & $\begin{array}{l}\text { Coseismic and } \\
\text { permanent }\end{array}$ & $6.2 \pm 0.1^{\mathrm{y}}$ & $\begin{array}{l}\text { moderate, if sediment type } \\
\text { changes or floral and faunal } \\
\text { type and distribution changes } \\
\text { are incorporated into } \\
\text { stratigraphic record }\end{array}$ & LOW & $\begin{array}{l}\text { possible, if sediment type } \\
\text { changes or floral and faunal } \\
\text { type and distribution changes } \\
\text { are preserved }\end{array}$ & $\begin{array}{l}\text { no, although coastal } \\
\text { strata terraces and } \\
\text { faunal assemblages } \\
\text { subject to ongoing } \\
\text { research }\end{array}$ & $\begin{array}{l}\text { no, changes in relative or } \\
\text { absolute sea level, changes in } \\
\text { tidal dynamics or sediment } \\
\text { flux, changes in hydrology, } \\
\text { shaking or sediment } \\
\text { loading-induced subsidence, } \\
\text { counteraction of uplift by } \\
\text { subsidence can all create } \\
\text { apparent uplift or subsidence } \\
\text { in the absence of faulting }\end{array}$ & VII-IX \\
\hline
\end{tabular}

Temporal naure $=$ permanent, temporary (possibility of feature being removed within weeks to years), transient (possibility of rapid removal within seconds to weeks).

x estimated minimum $\mathrm{M}_{\mathrm{w}}$ to generate discrete surface rupture and/or fault scarp sourced from $\mathrm{M}_{\mathrm{w}}$ estimates for sources that did and did not generate surface rupture in the CES after Beavan et al., 2012 and Elliott et al., 2012.

y estimated minimum $\mathrm{M}_{\mathrm{w}}$ to generate surface deformation identifiable from field observations and/or remote sensing data (INSAR, differential lidar), $\mathrm{M}_{\mathrm{w}}$ estimates from Beavan et al., 2012 and Elliott et al., 2012.

y estimated $\mathrm{M}_{\mathrm{w}}$ for western segment of Greendale Fault where avulsion occurred, from Beavan et al., 2012 and Elliott et al., 2012. 
segments (restraining step) was $\sim 1.1 \mathrm{~km}$ wide. Maximum horizontal slip was $5.2 \pm 0.2 \mathrm{~m}$, maximum vertical slip was $1.45 \pm 0.2 \mathrm{~m}$, and average net surface displacement was $2.5 \pm 0.1 \mathrm{~m}$, all of which occurred on the central segment (Quigley et al., 2012). Slip profiles reveal increases from minima at fault tips to maxima in the central segment of the Greendale Fault. The surface deformation zone ranged from 30 to $300 \mathrm{~m}$ in width (Fig. 7B) with an internal zone of discrete surface fracturing that ranged in width from 5 to $50 \mathrm{~m}$ (Fig. 7C).

\subsubsection{Seismic triggering thresholds}

The smallest earthquake source with an observed surface rupture was the western segment of the Greendale Fault $\left(\mathrm{GF}_{\mathrm{w}}, \mathrm{M}_{\mathrm{w}} 6.6\right.$; Beavan et al., 2012), and the largest isolated fault that did not cause surface rupture was the Sandy Knolls Fault (SKF; Fig. 3) $\left(M_{w} 6.5\right.$; Beavan et al., 2012), suggesting a surface-rupturing $M_{w}$ threshold of $6.6 \pm 0.1$ for the study region (ignoring the effects of fault geometry and kinematics) (Table 2A). This is consistent with the absence of surface rupture in the largest CES aftershocks (e.g. $\mathrm{M}_{\mathrm{w}} 6.2$ Christchurch and 6.0 June events). Small surface cracks on sealed roads with minimal $(<1-10 \mathrm{~cm}$ displacement) were mapped locally in the vicinity of the surface projections of the Hororata Anticline Fault (HAF, $\mathrm{M}_{\mathrm{W}}$ 6.31; Fig. 3) and southern segment of the Charing Cross Fault $\left(\mathrm{CCF}_{\mathrm{S}}\right.$, $\mathrm{M}_{\mathrm{W}} 6.44$; Fig. 3) and to the southeast of the Greendale Fault East (Fig. 3) following the $M_{w}$ 7.1 Darfield earthquake (Barrell, 2010).

\subsubsection{Palaeoseismic implications}

Only $20 \mathrm{~km}$ of the surface rupture length on the Greendale Fault was associated with discrete surface fracture; the remaining $\sim 10 \mathrm{~km}$ of surface rupture length occurred via broad wavelength surface folding in the absence of discrete fracturing (Van Dissen et al., 2011; Barrell et al., 2011). Without anthropogenic markers, much of the distributed folding deformation on the Greendale Fault, including areas adjacent to discrete faulting, would not have been detectable from field observations. Discrete surface fractures in the zone of surface fracturing accommodated about one third of the total displacement (Hornblow et al., 2014). The threshold above which granular deformation and broad folding transitioned to discrete faulting from was $\sim 1 \mathrm{~m}$ displacement per $100 \mathrm{~m}$ of fault zone width.

Much of the surface evidence for the Greendale Fault rupture was rapidly removed (within 2-3 wks of the $M_{w} 7.1$ Darfield earthquake) by farmers in order to resume agricultural land use. Analysis of historical aerial photographs revealed no unambiguous evidence of pre-CES surface faulting along the Greendale Fault prior to the CES (Villamor et al., 2012; Hornblow et al., 2014). From a palaeoseismic perspective, it is worth considering how the surface rupture will remain in the geologic record.

Confined fault traces with large (e.g. $\geq 0.5 \mathrm{~m}$ ) vertical displacements (e.g., fault scarps or pop-ups) remain visible in the field and on aerial photographic images (e.g., GFw), and in the absence of major anthropogenic modification are likely to persist as geomorphic anomalies for $>10^{2}$ to $10^{4} \mathrm{yrs}$. Areas where the fault scarp has displaced or severely damaged trees are still discernible, as are areas where grass or crop growth appears to still be affected by subsurface soil structure disruption and associated changes in moisture characteristics due to faulting. In an anthropogenically undisturbed (i.e. 'natural') environment it is likely that many of these features would be removed or obscured by erosion to the stage where they are challenging to recognise in 10 s to 100 s of yrs. Lateral displacements on fields where no linear agricultural markers are present (e.g., roads, tree lines, irrigation channels, crop rows) are currently challenging to recognise and interpret, even where $>1-2 \mathrm{~m}$ of discrete displacement has occurred, due to the lowrelief nature of the land surface, the subtle topography associated with palaeochannel margins, and absence of other sharply defined natural features that would enable offset measurements. By calculating the total distance between individual locations where surface deformation is discernible in the absence of agricultural features, and terminating the observable deformation extent where point-to-point distances exceed $2 \mathrm{~km}$, we estimate that $\sim 12 \mathrm{~km}$ of the total surface rupture length is currently observable ( $40 \%$ of total surface rupture length, $\sim 14 \%$ of subsurface rupture length). Although estimates of vertical coseismic surface displacement could be confidently obtained at several locations, we could not find any non-agricultural surface features (e.g., palaeochannels) where reliable measurements of coseismic lateral surface displacement could be made.

Trenching investigations of the Greendale Fault following the $M_{w} 7.1$ Darfield earthquake revealed (i) a $21.6 \pm 1.5$ ka (optically stimulated luminescence (OSL) age in thousands of years before present (ka)) buried palaeochannel at $0.6 \mathrm{~m}$ depth with $0.6 \mathrm{~m}$ of lateral displacement, and (ii) two buried palaeochannels at $\sim 2.5 \mathrm{~m}$ depth (OSL ages of $28.4 \pm$ $2.4 \mathrm{ka}$ and $33 \pm 2 \mathrm{ka}$ ) with $1.2 \mathrm{~m}$ lateral displacement (Hornblow et al., 2014). These data were interpreted to indicate that the penultimate surface-rupturing earthquake on the Greendale Fault occurred between ca. 20 and $30 \mathrm{ka}$ and that any surface evidence for faulting such as fissures and scarps was subsequently eroded and buried during Late Pleistocene alluvial activity. The recognition of an offset channel with a single-event displacement indicates that geologic evidence for the $M_{w}$ 7.1 Darfield earthquake will persist in some locations in the subsurface. However, given (i) the abandonment of much of the ruptured surface at ca. 18-20 ka with minimal to no subsequent sedimentation (Hornblow et al., 2014), (ii) the lack of non-agricultural surface features with clear evidence for lateral surface rupture displacements, and (iii) the small $(\sim 30 \%)$ of total displacement manifested as discrete fracturing in the hosting sediments, we conclude that the timing of the $M_{w}$ 7.1 Darfield earthquake based on the geologic record would be poorly constrained to sometime after $\sim 21 \mathrm{ka}$ and before 2010. Even this would require datable evidence for surface sediment remobilisation post 2010, e.g., colluvial wedges). The total coseismic displacement would be estimated at $\geq 60 \pm 10 \mathrm{~cm}$.

\subsection{Surface deformation above blind faults}

\subsubsection{Effects and distribution}

Surface folding with wavelengths $\geq 2-3 \mathrm{~km}$ and amplitudes $\geq 40 \mathrm{~cm}$ was observed in the area surrounding the surface projection of the Hororata Anticline and Charing Cross Faults following the $M_{w} 7.1$ Darfield earthquake (Fig. 7A). An area of $\sim 15 \mathrm{~km}^{2}$ adjacent to the Charing Cross fault had surface deformation with broad wavelength uplift $>1 \mathrm{~m}$. An area of $\sim 130 \mathrm{~km}^{2}$ on the south side of the Greendale Fault and $49 \mathrm{~km}^{2}$ above the Hororata anticline fault was uplifted $>0.2 \mathrm{~m}$. The Greendale Fault uplift was subtle and widespread, whilst the Charing Cross Fault uplift was more localised with a steeper gradient (Fig. 7A).

The $\mathrm{M}_{\mathrm{w}}$ 6.2 Christchurch earthquake caused a clear signature of tectonic uplift ( $0.45 \mathrm{~m})$ around the Avon-Heathcote Estuary in the hanging wall of blind reverse-oblique faults (Fig. 8). Cumulative tectonic footwall subsidence in the $M_{w} 6.2$ Christchurch earthquake, inferred from fault source models (Beavan et al., 2012) with non-tectonic subsidence removed, reached $0.18 \mathrm{~m}$ (Fig. 8E). Tectonic surface deformation caused coastal and near-coastal vertical elevation changes; most notably to the Avon-Heathcote Estuary (AHE). Differential elevation analysis for the AHE (Fig. 8F) shows that $76 \%$ of its area has uplifted

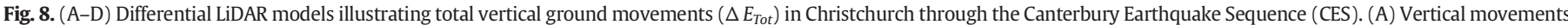

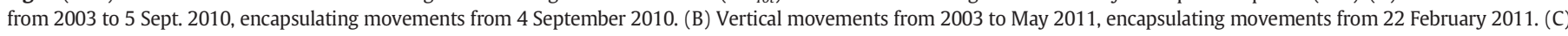

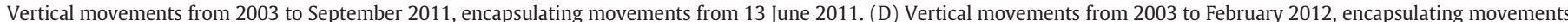

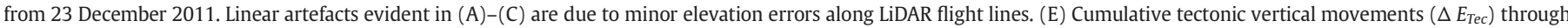

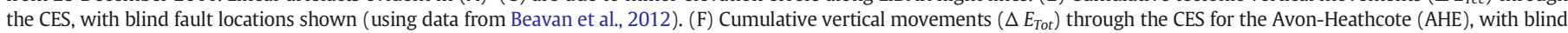
fault locations shown. Linear artefacts in (F) are due to minor elevation errors due to interpolation between ground survey and depth-sounder survey transects. 
through the CES, $60 \%$ of the area is in the $0-0.4 \mathrm{~m}$ uplift range corresponding to the cumulative CES tectonic signature. AHE uplift reduced the tidal prism and increased the area of exposed at mid-tide by $18 \%$
(Measures et al., 2011), and exposed the southern estuary in particular to increased drying. Using a calibrated hydrodynamic model (Measures and Bind, 2013), neap and spring tidal prism volumes are calculated to

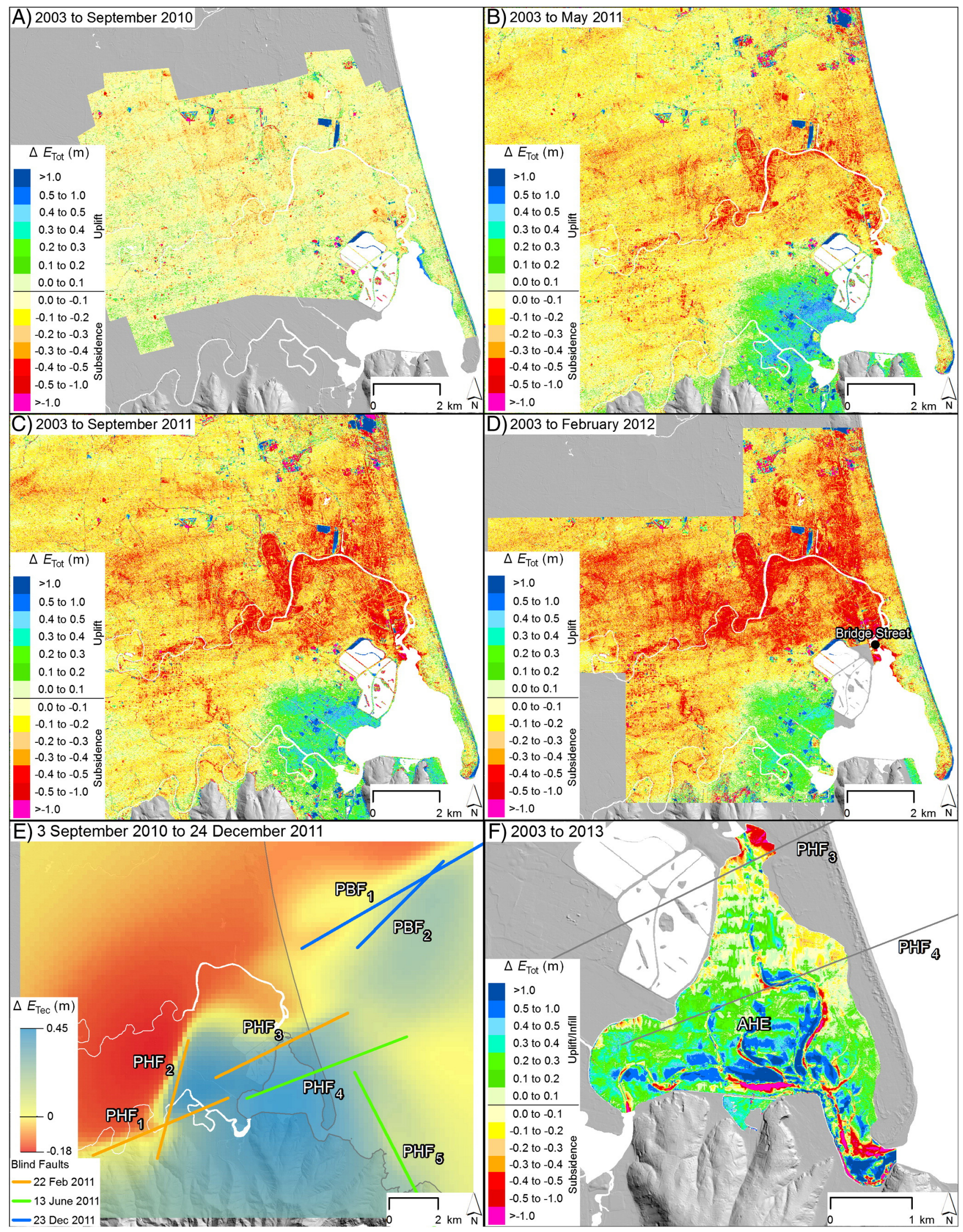


have reduced by $17.6 \%$ and $12.4 \%$, respectively, with an average tidal prism reduction of $14.6 \%$.

\subsubsection{Seismic triggering thresholds}

The smallest $\mathrm{M}_{\mathrm{w}}$ blind fault earthquakes to generate differential surface elevation changes as great as the potential error in remote sensing imagery and airborne LiDAR data $(>10-20 \mathrm{~cm})$ as a result of blind faulting were the Hororata anticline reverse fault $\left(\mathrm{M}_{\mathrm{w}} \sim 6.3\right.$; HAF; Fig. 7A) rupture during the $M_{w} 7.1$ Darfield earthquake and the Port Hills reverse-oblique fault ruptures in the $M_{w} 6.2$ Christchurch earthquake (Beavan et al., 2012). The largest source component $M_{w}$ earthquakes where vertical surface deformation is not easily identified from LiDAR and remote sensing data were the $\mathrm{M}_{\mathrm{w}} 6.4$ left-lateral $\left(\mathrm{CCF}_{\mathrm{N}}\right.$, Fig. 3) and $\mathrm{M}_{\mathrm{w}} 6.5$ right-lateral (SKF, Fig. 3) faults that ruptured during the $\mathrm{M}_{\mathrm{w}}$ 7.1 Darfield earthquake (Beavan et al., 2012). We thus assign an earthquake magnitude threshold of $\mathrm{M}_{\mathrm{w}} 6.3 \pm 0.2$ for the generating environmentally discernible tectonic surface deformation in this environment (Table 2A), whilst acknowledging that the subtle and broadly distributed nature of this deformation, and potential variations in hypocentral depth, geologic structure and basement rock depth, rupture proximity to ground surface, fault kinematics and slip distributions contribute variables that introduce uncertainties in this estimate.

\subsubsection{Palaeoseismic implications}

Whether surface deformation resulting from blind faulting during the CES is manifested in the geomorphic record as evidence for tectonism depends upon the balance between fault vertical slip rates and surface processes (e.g. sedimentation and erosion) that would obscure or remove evidence for faulting (McCalpin, 2009). In the case of the $M_{w}$ 7.1 Darfield earthquake structures, a variety of analogous NEstriking thrust faults have been identified to the north and west of the CES faults based on geomorphic evidence for folding at the surface (e.g., Hororata Fault, Racecourse Hill anticline, Springbank Fault, Cust anticline; Fig. 2)(Campbell et al., 2012). Surface doming has also occurred at intersections of NE- and E-W striking faults (Campbell et al., 2012). The abandonment of the alluvial surface post LGM in the western and central Canterbury Plains means that the tectonic folding observed in the CES is likely to persist over geologic time scales. Although the broad wavelength and typically small total displacement on the CES structures during the $\mathrm{M}_{\mathrm{w}}$ 7.1 Darfield earthquake will present a significant challenge to identification, cumulative tectonic displacements over multiple earthquakes will result in progressive fold growth and more prominent geomorphic expression of features such as the Hororata anticline fault and Charing Cross fault in the absence of alluvial erosion and sedimentation. Possible river responses to vertical deformations on the CES faults are discussed in Section 5.3.

It is highly unlikely that evidence for surface tectonic deformation in the $\mathrm{M}_{\mathrm{w}}$ 6.2 Christchurch earthquake and other large aftershocks will persist in a fashion that will be easily identifiable from geologic or geomorphic data. Given shoreline progradation eastwards from a position in western Christchurch from 6.5 ka to its current position (Fig. 2), any subtle evidence for pre-CES surface deformation on faults responsible for the $M_{w} 6.2$ Christchurch and 6.0 earthquakes would have been buried and/or eroded. The dynamic nature of Christchurch's urban rivers and coastlines, together with the past and future extents of sealevel fluctuations, will exert sufficient change on the landscape to the extent that it is highly unlikely that any direct surface evidence for local tectonic deformation would remain in the absence of human intervention.

Finally, it is worth considering whether tectonic uplift of the bedrock shore platforms along the rocky coastal cliffs of Banks Peninsula during the CES will provide an interpretable palaeoseismic archive of these earthquakes. The position of these shore platforms with respect to the CES faults meant that no discernible (i.e. $>10 \mathrm{~cm}$ ) tectonic uplift occurred as a result of the CES (Beavan et al., 2012). Relict shore platforms in southwest Banks Peninsula at 6-8 $\mathrm{m}$ above sea level interpreted to be Last Interglacial in age (Lawrie, 1993) suggest either vertical stability or low rates of late Quaternary surface uplift at 0 to $0.04 \mathrm{~mm} \mathrm{yr}^{-1}$; with the upper bound set by assuming highest platform elevations and lowest range of last interglacial (ca. $125 \mathrm{ka}$ ) sea level of $3 \mathrm{~m}$ above present (Williams et al., 2015). It is noted that caution is required in interpreting the origin of these features (Barrell, 2000), and the extent to which geologic data are consistent with geodetic data remains uncertain. A 10 year continuous GPS record from station MQZG in southwest Banks Peninsula (Fig. 2) suggests subsidence of $0.8 \pm 0.2 \mathrm{~mm} \mathrm{yr}^{-1}$. Total vertical coseismic displacements at MQZG in the CES $(\sim 14 \mathrm{~mm}$ up in $\mathrm{M}_{\mathrm{w}}$ 7.1 Darfield earthquake, $3 \mathrm{~mm}$ down in Christchurch $\mathrm{M}_{\mathrm{w}} 6.2$ earthquake) indicate only $\sim 1 \mathrm{~cm}$ of cumulative uplift. Given the uncertainties in platform ages, elevations and relationships to true sea level, together with uncertainties in how accurately geodetic measurements reveal long-term change, it is likely that any coseismic vertical displacements in the Port Hills and other parts of Banks Peninsula will be small and infrequent enough that extracting signals of the CES and analogous earthquake events will be extremely challenging.

\subsection{River avulsion, river gradient changes, and flooding}

\subsubsection{Effects and distribution}

Surface deformation on the western and central segments of the Greendale Fault caused partial avulsion of the Hororata River (Fig. 7D; Quigley et al., 2010c; Barrell et al., 2011; Duffy et al., 2013). Along the western segment of the Greendale Fault, a monoclinal flexure of the surface gravels formed an upstream-facing, 1.6-m-high, dextral-normal, coseismic scarp across a meander bend in the Hororata River (Figs. 2, 7D, \& 19 [4]; Quigley et al., 2010a; Barrell et al., 2011; Duffy et al., 2013). The scarp impeded downstream flow and caused partial avulsion of the Hororata River, directing floodwaters down the regional gradient to the southeast, parallel to and generally within $100 \mathrm{~m}$ of the scarp (Fig. 19 [5]). Apart from the avulsion locality, the remainder of the GFW fault trace remained entirely within the Hororata-Selwyn interfluve along the entire $5 \mathrm{~km}$ of surface expression (Duffy et al., 2013) and for at least a further $5 \mathrm{~km}$ northwestward (Beavan et al., 2010). This made it difficult to discriminate fluvial terrace risers from tectonic scarps. LiDAR was unavailable over most of the GFW, so mapping of the avulsion floodwater along the scarp was instrumental in defining the location of the GFW, guiding fenceline surveys and revealing subtle features such as slight strike changes and the presence of a small left stepover (Duffy et al., 2013).

Twenty eight hectares of floodwaters on the hanging wall of the fault lapped onto the scarp and highlighted its geometry. The floodwaters passed across the scarp through two palaeochannels (Fig. 19[6]), flooding a further 23 ha on the footwall of the fault. North (upstream) of the avulsion node, hanging wall flooding occurred because the fault scarp dammed an ephemeral, locally 3 m deep, Selwyn River palaeochannel that links the modern Selwyn and Hororata Rivers (Fig. 19[7]) (Duffy, 2012). The fault dam created a narrow $\sim 3$ ha fault-bounded lake that filled with groundwater expelled during a rapid rise in groundwater levels (Cox et al., 2012).

The Selwyn River crossed the Greendale Fault at the releasing bend between the $\mathrm{GF}_{\mathrm{W}}$ and Greendale Fault central segments (Duffy et al., 2013). No coseismic scarp impeded the river but upstream of the Greendale Fault, the bed of the Selwyn River subsided by $<1.2 \mathrm{~m}$ on the hanging wall of the $\mathrm{GF}_{\mathrm{W}}$ (Duffy et al., 2013), steepening the upstream profile and flattening the downstream profile gradient from $0.5 \%$ to $0.4 \%$ (Fig. 19 [11]). This reduction is likely to favour gravel deposition in the flattened reaches of the river. The $\mathrm{GF}_{\mathrm{W}}$ surface trace is therefore a subtle, potentially ambiguous feature that is susceptible to erosion by the Hororata River and burial by the Selwyn River.

Tectonic surface displacements during the $\mathrm{M}_{\mathrm{w}} 6.2$ Christchurch earthquake and, to a much lesser extent the $M_{w} 6.0$ June earthquake, 

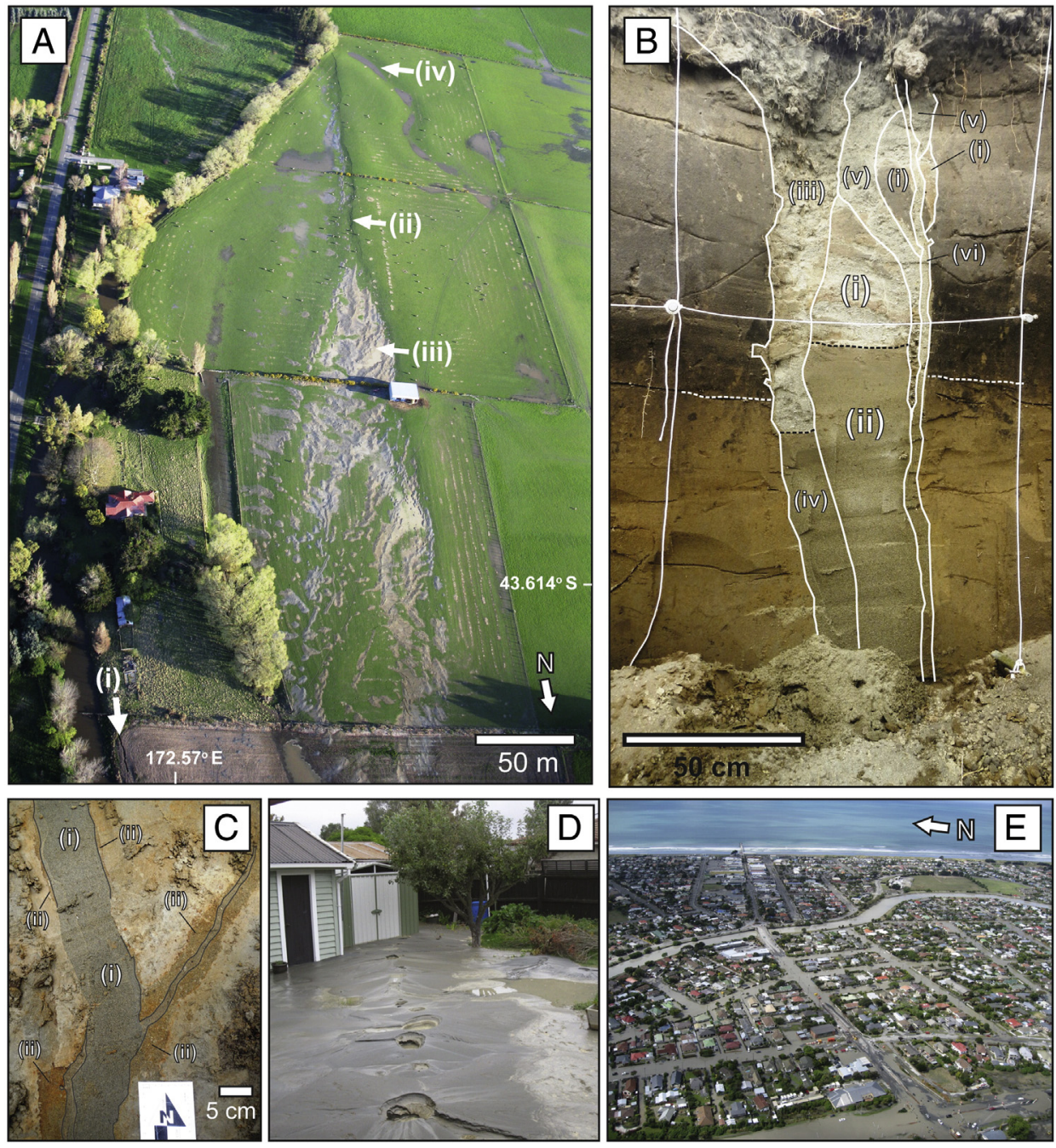

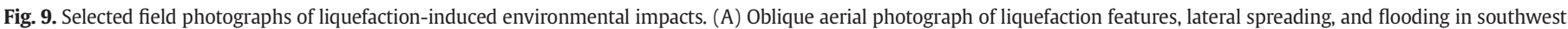

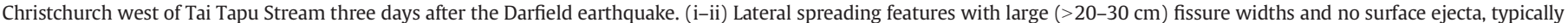

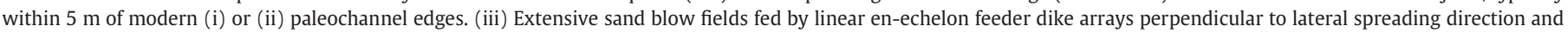

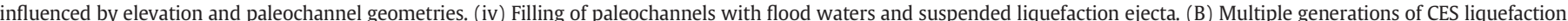

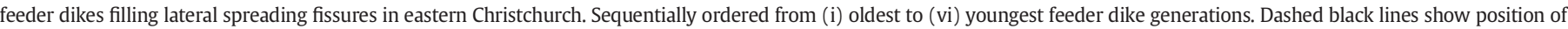

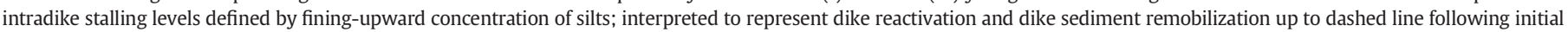

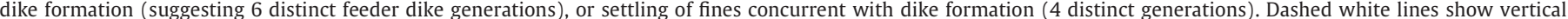

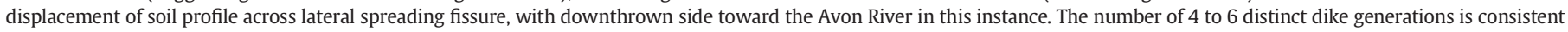

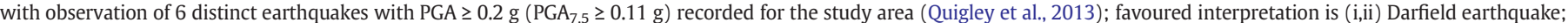

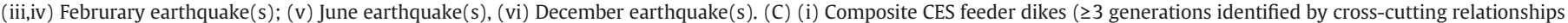

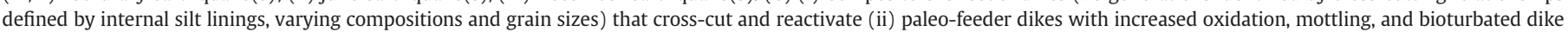

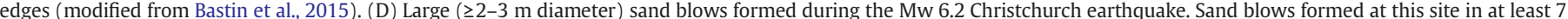

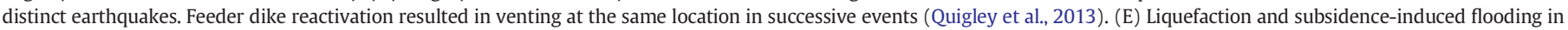

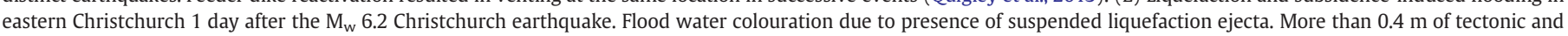
vertical subsidence has resulted in elevations.

affected the gradients of the major urban rivers (Hughes et al., 2015). The @Avon River upstream of the Avon-Heathcote Estuary (AHE) subsided where it flowed across the footwall of one of the $\mathrm{M}_{\mathrm{w}} 6.2$ Christchurch earthquake fault ruptures (PHF 3; Figs. 8B \& 19[14]). The upper reaches of the Heathcote River also subsided, whereas the lower reaches were uplifted on the hanging wall of two of the $M_{w} 6.2$ Christchurch earthquake fault ruptures (PHF 1, 2; Fig. 8B). The tectonically-induced gradient changes on the Heathcote River are expected to increase flooding in the upstream reach, whilst the tectonic uplift of the AHE is expected to increase flooding in both the Avon and Heathcote Rivers (Allen et al., 2014; Hughes et al., 2015). The tectonic subsidence of the Avon River has lowered the channel with respect to sea level, increasing flood potential along the river. Flood hazard has also been exacerbated along the Avon River due to (i) narrowing and shallowing of the stream channel due to lateral spread of river banks and deformation of channel floor; (ii) shallowing of the stream channel due to sedimentation from liquefaction ejecta entering waterways, and (iii) liquefaction-induced subsidence of surrounding floodplains. Lowering of surface elevations relative to water tables (van Ballegooy et al., 2014a, 2014b, 2014c) is also likely to have increased the liquefaction and flood hazard. With groundwater levels (i.e., fully saturated soils) now closer to the ground surface, there is less capacity for the soil to absorb water during storm events. Leakage from underlying artesian aquifers through breached aquitards may also have influenced local hydrologic conditions (Cox et al., 2012) and influenced surface water infiltration. 


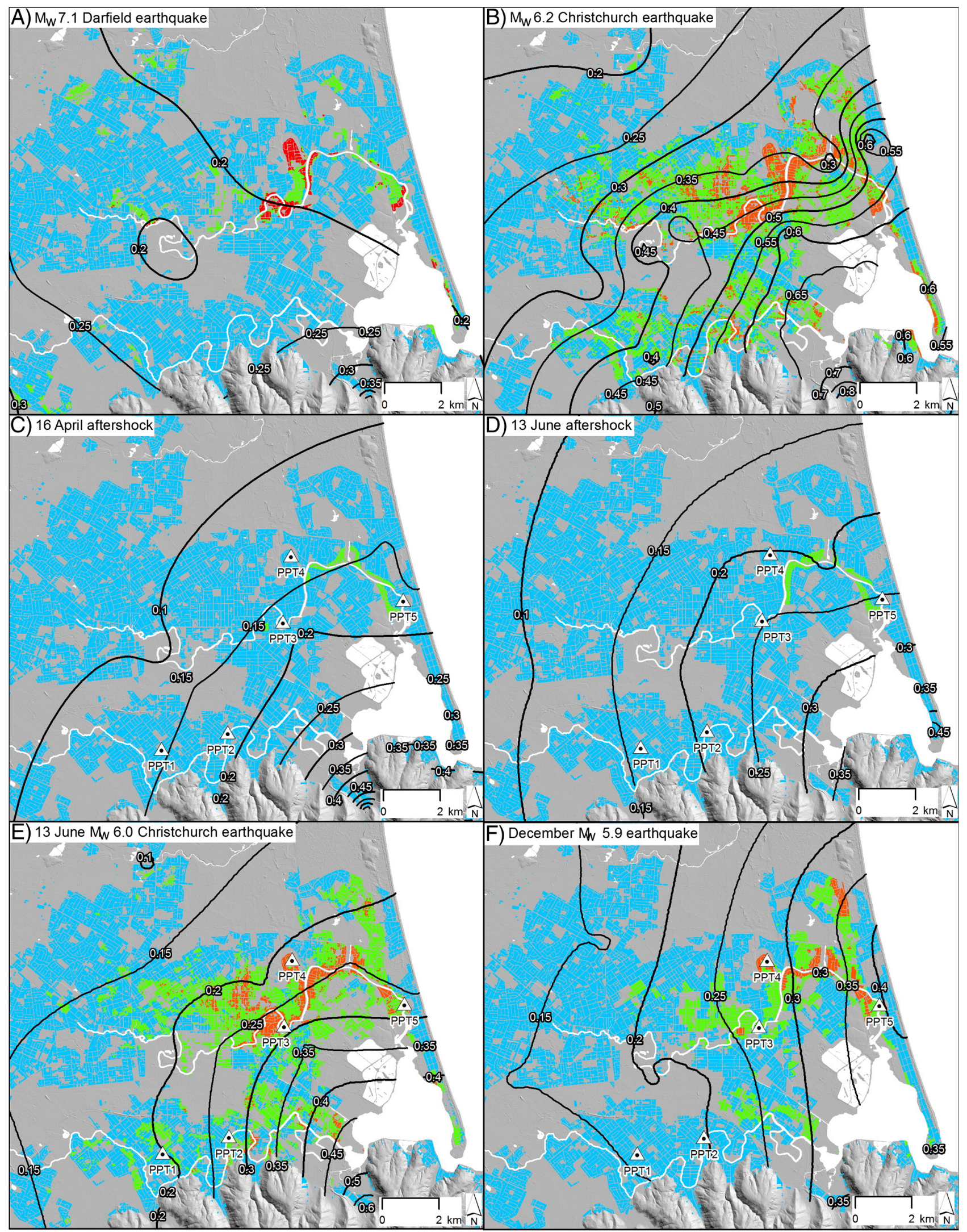

$\frown$ Peak Ground Acceleration - $0.05 \mathrm{~g}$ contours

- Pore Pressure Transducer (PPT) location

Liquefaction Manifestation

Moderate to severe Minor to moderate None to minor No observations 


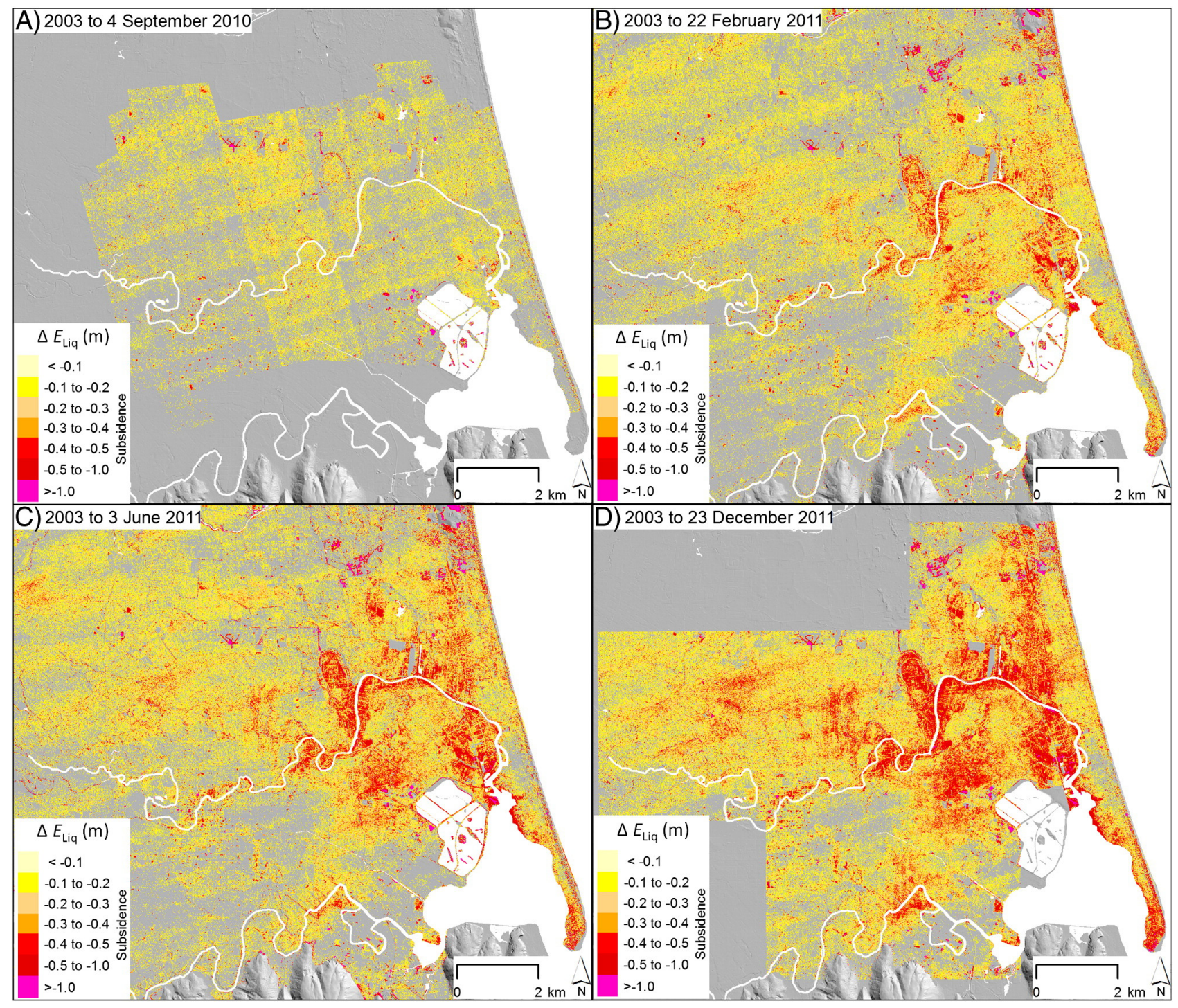

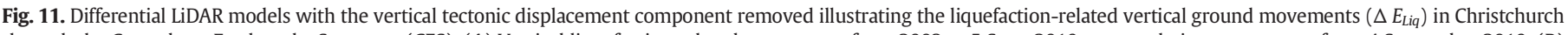

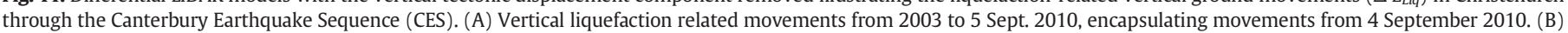

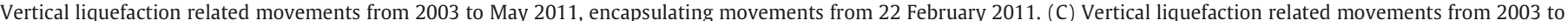

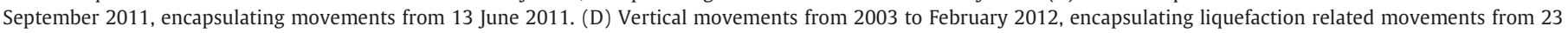
December 2011. Linear artefacts evident in (A)-(C) are due to minor elevation errors along LiDAR flight lines.

\subsubsection{Seismic triggering thresholds}

River avulsion due to discrete surface faulting is expected to have the same $\mathrm{M}_{\mathrm{w}}$ threshold as that required to induce surface rupturing (6.6 \pm 0.1 in this setting). Given that gradients of Christchurch's rivers were influenced by folding above blind faults, we infer that the surface folding $\mathrm{M}_{\mathrm{w}}$ threshold of $6.3 \pm 0.2$ provides an estimate of the minimum $\mathrm{M}_{\mathrm{w}}$ required in order to induce environmentally perceivable changes in stream gradient.

\subsubsection{Palaeoseismic implications}

Apart from the avulsion locality, the $\mathrm{GF}_{\mathrm{W}}$ trace remained entirely within the Hororata-Selwyn interfluve along the entire $5 \mathrm{~km}$ of surface expression (Duffy et al., 2013) and for at least a further $5 \mathrm{~km}$ northwestwards (Beavan et al., 2010). Due to the lack of LiDAR over the GFW, the fault trace was distinguishable mainly from fluvial topography by surveying of fencelines and mapping of the co-seismic flooding. In the absence of anthropogenic features, it would have been challenging to easily distinguish the fault scarp from alluvial terrace risers in many instances.

The Selwyn and Hawkins Rivers, near the triple junction of the Greendale Fault central segment, $\mathrm{GF}_{\mathrm{W}}$, and $\mathrm{CCF}_{\mathrm{S}}$ (Fig. 7A), both exhibit traits that indicate that they have responded to Holocene tectonism and surface folding on the Greendale Fault (Campbell et al., 2012). On the downthrown north side of the Greendale Fault trace, the Hawkins River is increasingly wide and sinuous. Across the coseismic uplift

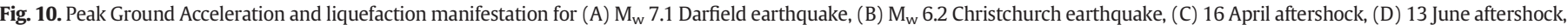

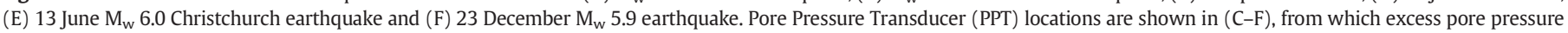

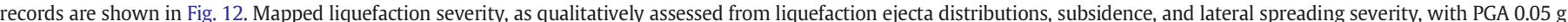

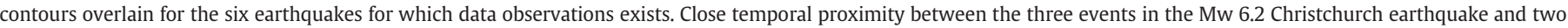

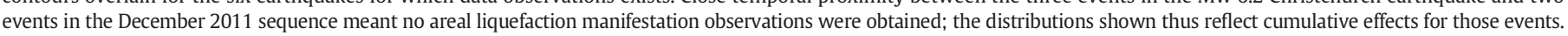
Minor to moderate liquefaction in susceptible loose sediments with a low resistance to liquefaction triggering occurred at $0.1 \mathrm{~g}$ 


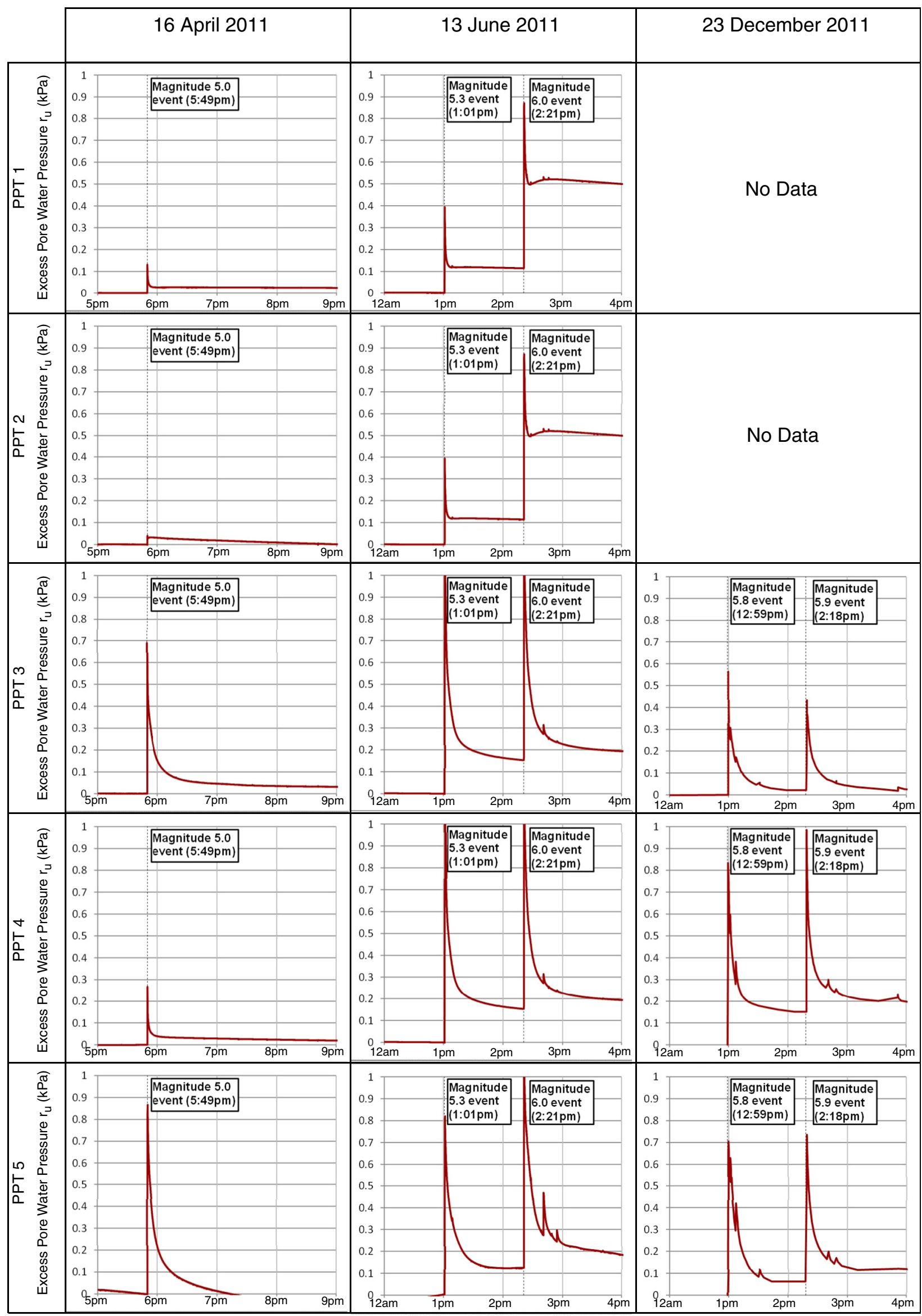




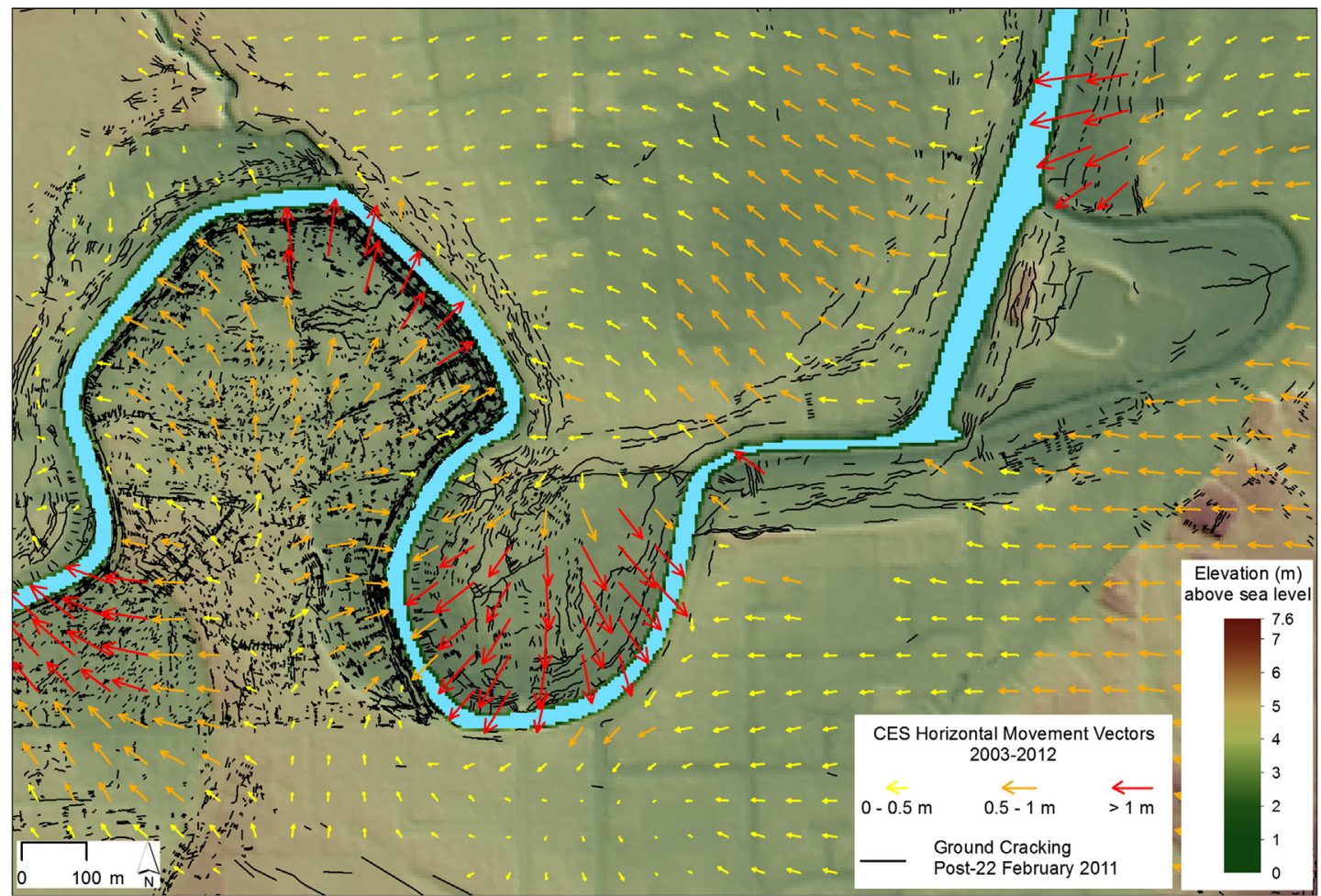

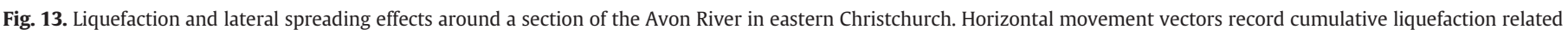

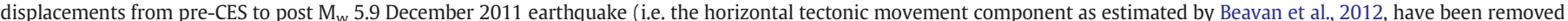

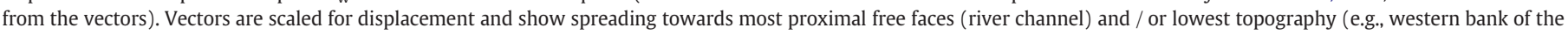

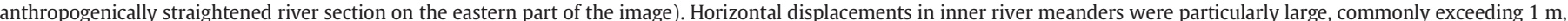

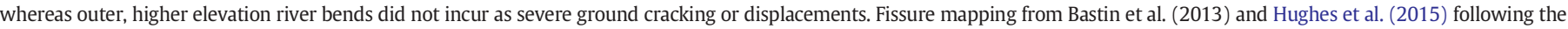

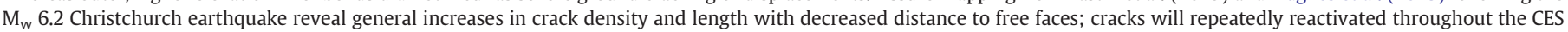
however the effects in this area were most severe $M_{w} 6.2$ Christchurch earthquake (Quigley et al., 2013).

zone, the Hawkins River is more deeply incised into the land surface and has decreased channel width and abandoned terraces. On the southern flank of the coseismic uplift, the Selwyn River has migrated southward.

Seismic reflection surveys of the central Greendale Fault and a fault that probably represents one of the $M_{w} 6.2$ Christchurch earthquake faults (PHF 3; Fig. 3) reveal that vertical displacements increase with depth, implying that at least some of the CES faults have been active throughout the Quaternary (Lawton et al., 2011).

\subsection{Liquefaction, lateral spreading and subsidence effects}

\subsubsection{Effects and distribution}

The main CES events triggered localised to widespread, minor to severe liquefaction and related effects in parts of Christchurch and the surrounding region (Figs. 8-14). Liquefaction-induced effects are documented in Cubrinovski and Green (2010), Cubrinovski et al. (2011a, 2011b), Wotherspoon et al. (2012), Green et al. (2012), Tonkin and Taylor Limited (2013), Quigley et al. (2013), van Ballegooy et al. (2014a, 2014c, 2015b), Maurer et al. (2014a, 2014b), Bastin et al. (2015), Rogers et al. (2015) and Villamor et al. (2016) amongst others. The most severe and spatially extensive liquefaction-related effects manifested at the ground surface occurred as a result of the $M_{w} 7.1$
Darfield, $\mathrm{M}_{\mathrm{w}}$ 6.2 Christchurch, $\mathrm{M}_{\mathrm{w}} 6.0$ June and $\mathrm{M}_{\mathrm{w}}$ 5.9 December earthquakes (Fig. 10). Up to seven other CES earthquake events were observed to have manifested liquefaction-related effects at the ground surface (Table S1; electronic supplement). Some other CES events may have triggered liquefaction in isolated soft/loose soil layers but did not result in any observable manifestation at the ground surface. Surface manifestations of liquefaction included water, sand and silt ejecta typically deposited at the ground surface as sand and silt blows (sand volcanoes), differential ground surface subsidence, oscillation cracks, lateral spreading fissures, lateral spreading stretch zones and compression zones, voids (sinkholes), and liquefaction-related subsidence (Figs. 9, 11).

Observations of ejected material and lateral spreading based on field inspection in residential areas and supplemented by visual observation from aerial photography following each significant earthquake were used to map liquefaction severity following each major (i.e. $\mathrm{M}_{\mathrm{w}}>5$ to 5.5) earthquake (Fig. 10). Following the $M_{w} 7.1$ Darfield earthquake, liquefaction manifestation at the ground surface affected $\sim 10,000$ residential properties and was generally confined to specific low-elevation $(<5$ masl $)$ suburbs with shallow $(<1 \mathrm{~m}$ depth) groundwater tables (van Ballegooy et al., 2014a) and thick ( $>2 \mathrm{~m}$ ) near-surface layers of loose to medium density sandy soils. Liquefaction triggering in specific

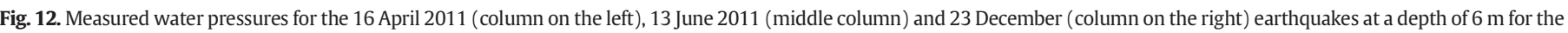

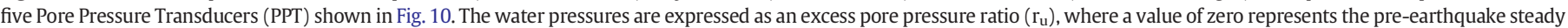

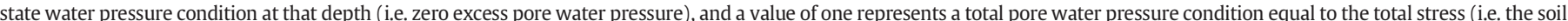

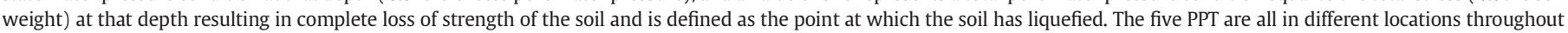

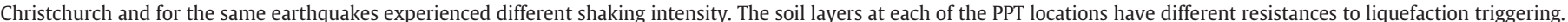

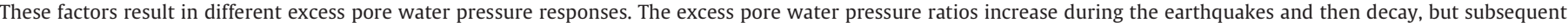

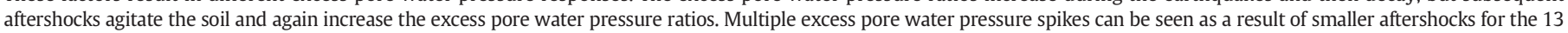
June and 23 December events particularly in the PPT3, 4 and 5 locations where the soils are loose and have a very low resistance to liquefaction triggering. 


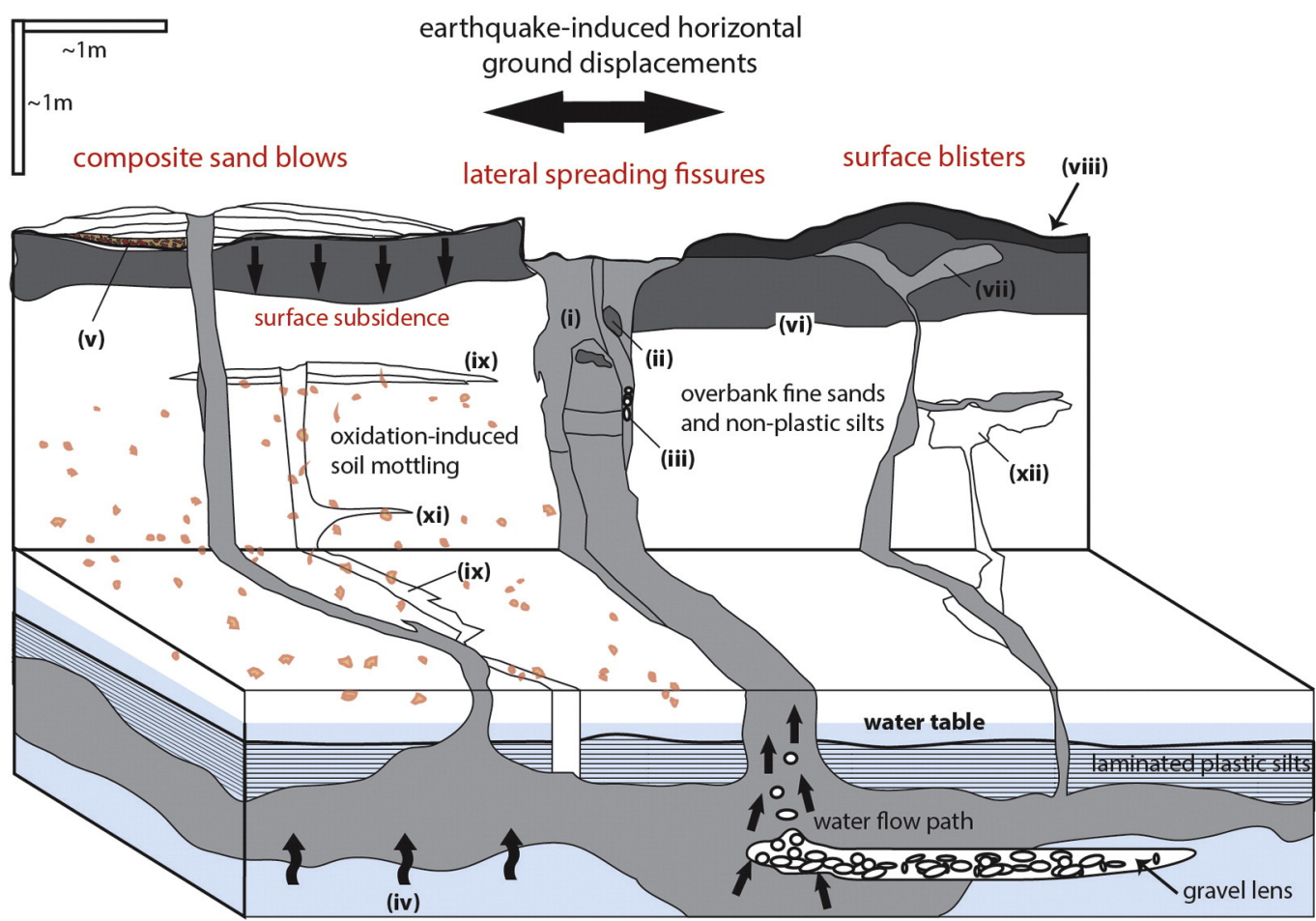

(i) reactivated feeder dike with multiple injections

(ii) dike-entrained soil clasts

(iii) dike-entrained fluvial pebbles

(iv) possible influx of deeper artesian waters

(v) buried vegetative matter beneath sand blows

(vi) depth of soil profile development

(vii) splaying feeder dikes below surface blister (viii) high density soil cap

(ix) paleoliquefaction - buried sand blow

(x) paleoliquefaction - oxidized, mottled feeder dike

(xi) paleoliquefaction - sill

(xii) paleoliquefaction - bulbous 'stalled' intrusion

Fig. 14. Summary schematic diagram of liquefaction and paleoliquefaction features observed from surface and subsurface investigations (e.g., Quigley et al., 2013; Bastin et al., 2015).

soil layers was widespread and extensive in the $\mathrm{M}_{\mathrm{w}} 7.1$ Darfield earthquake, as indicated from large areal extents of subsidence (Hughes et al., 2015) in areas underlain by liquefiable sediments, even though there was only observed severe ground surface manifestation in isolated areas (Fig. $10 \mathrm{~A}$ ). The evidence for this can also be seen from the LiDAR difference maps with the vertical tectonic changes in elevation removed (Fig. 11), referred to herein as the liquefaction-related subsidence maps. These show extensive areas of liquefaction-related subsidence due to post-liquefaction volumetric densification, removal of liquefaction surface ejecta (Villemure et al., 2012; van Ballegooy et al., 2014c) and lateral spreading. The main reasons that liquefaction manifestation at the ground surface was confined only to specific isolated suburbs was 1 ) in other areas the liquefying soil layers were generally denser, resulting in less post-liquefaction volumetric densification and hence less expulsion of excess groundwater, and 2) the liquefying soil layers were more isolated and interbedded between soil layers that did not liquefy at the lower Darfield $M_{w}$ 7.1 PGAs relative to the $M_{w}$ 6.2 Christchurch earthquake (Figs. 6, 10), and/or were capped by relatively thick non liquefying soil crusts (either because of a deeper water table depths or near surface soil layers with a higher resistance to liquefaction) that prohibited liquefied sediment injections to reach the surface (Ishihara, 1985 and van Ballegooy et al., 2015a).

The October aftershock $\left(\mathrm{M}_{\mathrm{w}} 4.8\right)$ (Table 1 ) caused localised ground surface manifestation of liquefaction in a few small isolated areas in the southwestern areas of Christchurch (Cubrinovski et al., 2010) near the epicentre of this earthquake (Fig. 3). The PGA from this event at these sites is not well constrained due to the low density of proximal seismometers. The 2010 Boxing Day aftershock $\left(M_{w} 4.7\right)$ (Table 1$)$ is not known to have caused any surface manifestation of liquefaction in Christchurch.
The $M_{w} 6.2$ Christchurch earthquake caused the most widespread and severe liquefaction manifestation at the ground surface throughout central, southern and eastern Christchurch, relative to all the other CES earthquakes, affecting $\sim 7,000$ residential properties (Fig. 10). The most severe manifestations (typically 100 to $300 \mathrm{~mm}$ of ejected sand and silt covering areas of $>10$ to $100 \mathrm{~m}^{2}$ ) were generally observed in the lowelevation suburbs adjacent to the Avon River where the groundwater was close to the ground surface (van Ballegooy et al., 2014a) and the soils comprised thicker near-surface layers of loose to medium density sandy soils. The ground surface manifestations were less severe (i.e., smaller individual sand blows) in the suburbs farther away from the Avon River where groundwater was either deeper below the ground surface (van Ballegooy et al., 2014b) or the near-surface soil layers comprised medium density to dense sandy soils. Liquefaction caused widespread and severe subsidence throughout eastern and central Christchurch as a result of lateral spreading, topographic re-levelling, volume loss due to water, sand and silt ejecta to the ground surface and post-liquefaction volumetric densification (Fig. 11B). Generally, the areas where the largest volumes of water, sand and silt ejecta occurred also experienced the greatest amount liquefaction-related subsidence $(>0.5 \mathrm{~m})$. Any additional ground surface manifestations caused by $\mathrm{M}_{\mathrm{w}} 5.5$ and 5.6 aftershocks could not be distinguished from the liquefaction manifestation caused by the $M_{w} 6.2$ Christchurch earthquake due to the relatively short time span between these three events, with the exception of isolated sites where local residents confirmed liquefaction surface ejecta was also produced in the aftershocks (Quigley et al., 2013). The mapped liquefaction manifestations (Fig. 10B) are the combined effect of all three events, although the $M_{w} 5.5$ and 5.6 aftershocks generated PGA values locally that were most likely high enough to have caused liquefaction in 
Earthquake-induced environmental phenomena, associated seismologic thresholds for phenomenon initiation, and likely preservation potential in geologic record.

\begin{tabular}{|c|c|c|c|c|c|c|c|c|c|}
\hline $\begin{array}{l}\text { Shaking-induced } \\
\text { phenomena }\end{array}$ & $\begin{array}{l}\text { Seismic origin of } \\
\text { phenomenon }\end{array}$ & $\begin{array}{l}\text { Temporal } \\
\text { nature of } \\
\text { phenomenon }\end{array}$ & $\begin{array}{l}\text { Minimum } \\
\text { threshold } \\
\text { PGA (g) in } \\
\text { CES }\end{array}$ & $\begin{array}{l}\text { Preservation } \\
\text { potential in } \\
\text { stratigraphic } \\
\text { record }\end{array}$ & $\begin{array}{l}\text { Preservation } \\
\text { potential at } \\
\text { surface }\end{array}$ & $\begin{array}{l}\text { Preservation } \\
\text { potential in biologic, } \\
\text { geochemical, or } \\
\text { hydrologic record }\end{array}$ & $\begin{array}{l}\text { Pre-CES } \\
\text { 'palaeo' } \\
\text { features } \\
\text { identified? }\end{array}$ & $\begin{array}{l}\text { Diagnostic of } \\
\text { seismic origin? }\end{array}$ & $\begin{array}{l}\text { ESI-2007 } \\
\text { metric } \\
\text { (range } \\
\text { of max) }\end{array}$ \\
\hline 1. Liquefaction & $\begin{array}{l}\text { Shaking-induced } \\
\text { transformation of water } \\
\text { saturated sediments into } \\
\text { fluid-like state and ejection of } \\
\text { liquefied sediments to the } \\
\text { surface or shallow subsurface }\end{array}$ & $\begin{array}{l}\text { Coseismic to } \\
\text { shortly } \\
\text { postseismic } \\
\text { and } \\
\text { permanent }\end{array}$ & $0.11-0.15 \mathrm{~g}^{z z}$ & $\begin{array}{l}\text { High, feeder dikes and other } \\
\text { intrusions preserved in subsurface } \\
\text { but may underepresent total } \\
\text { number of liquefaction events due } \\
\text { to dike reactivation }\end{array}$ & $\begin{array}{l}\text { High, sand blows } \\
\text { preserved on the surface } \\
\text { at many locations } \\
\text { however alluvial and } \\
\text { aeolian erosion is } \\
\text { alternating their } \\
\text { morphology and may } \\
\text { complicate future } \\
\text { diagnosis }\end{array}$ & $\begin{array}{l}\text { Possible, differential } \\
\text { biologic colonisation of } \\
\text { sand blows, different } \\
\text { geochemical properties } \\
\text { from host sediment }\end{array}$ & $\begin{array}{l}\text { Yes, both sand } \\
\text { blows and } \\
\text { intrusions }\end{array}$ & $\begin{array}{l}\text { Mostly, although features } \\
\text { similar in appearance to } \\
\text { liquefaction features may be } \\
\text { produced by other } \\
\text { sedimentary processes } \\
\text { (Obermier, 1996) }\end{array}$ & VIII-XI \\
\hline $\begin{array}{l}\text { 2. Lateral } \\
\text { spreading }\end{array}$ & $\begin{array}{l}\text { Lateral surface and } \\
\text { near-surface displacement } \\
\text { resulting from pore pressure } \\
\text { build-up or liquefaction in } \\
\text { underlying sediments }\end{array}$ & $\begin{array}{l}\text { Coseismic to } \\
\text { shortly } \\
\text { postseismic } \\
\text { and } \\
\text { permanent }\end{array}$ & $0.15 \mathrm{~g}^{z z}$ & $\begin{array}{l}\text { High, alignment of feeder dikes } \\
\text { indicate lateral spreading fissures, } \\
\text { increased fissure density in areas of } \\
\text { maximum lat spreading, subsurface } \\
\text { record but may underepresent total } \\
\text { number of spreading events due to } \\
\text { fissure reactivation }\end{array}$ & $\begin{array}{l}\text { Low due to likelihood of } \\
\text { erosion and burial, but } \\
\text { subtle geomorphic } \\
\text { expression of lateral } \\
\text { spreading fissures } \\
\text { possible }\end{array}$ & $\begin{array}{l}\text { Possible, downdropping } \\
\text { of organics into fissures, } \\
\text { differential } \\
\text { geochemistry from host } \\
\text { sediment }\end{array}$ & $\begin{array}{l}\text { Yes, lateral } \\
\text { spreading } \\
\text { recorded by } \\
\text { palaeo feeder } \\
\text { dikes }\end{array}$ & $\begin{array}{l}\text { Mostly, although features } \\
\text { similar in appearance to lat } \\
\text { spreading features may be } \\
\text { produced by other processes } \\
\text { (Obermier, 1996) }\end{array}$ & VII -X \\
\hline $\begin{array}{l}\text { 3. Surface } \\
\text { subsidence } \\
\text { near rivers } \\
\text { and coasts and } \\
\text { related } \\
\text { biologic and } \\
\text { environmental } \\
\text { changes }\end{array}$ & $\begin{array}{l}\text { Subsidence induced by } \\
\text { liquefaction, lateral spreading, } \\
\text { mass movements, and/or } \\
\text { compaction }\end{array}$ & $\begin{array}{l}\text { Coseismic to } \\
\text { postseismic } \\
\text { and } \\
\text { permanent }\end{array}$ & $0.15 \mathrm{~g}^{z z}$ & $\begin{array}{l}\text { Moderate, if sediment type changes } \\
\text { or floral and faunal type and } \\
\text { distribution changes are } \\
\text { incorporated into stratigraphic } \\
\text { record }\end{array}$ & $\begin{array}{l}\text { Moderate, if biologic } \\
\text { assemblages persist }\end{array}$ & $\begin{array}{l}\text { Possible, if sediment } \\
\text { type changes or floral } \\
\text { and faunal type and } \\
\text { distribution changes are } \\
\text { preserved }\end{array}$ & $\begin{array}{l}\text { No, although } \\
\text { should be a } \\
\text { focus of future } \\
\text { research }\end{array}$ & $\begin{array}{l}\text { No, sea-level fluctuations, } \\
\text { storm surges, sediment } \\
\text { compaction and subsidence } \\
\text { provide alternative } \\
\text { mechanisms }\end{array}$ & na \\
\hline $\begin{array}{l}\text { 4. Onshore/ } \\
\text { offshore } \\
\text { sedimentation } \\
\text { changes }\end{array}$ & $\begin{array}{l}\text { Changes in terrestrial or } \\
\text { marine sedimentation rates } \\
\text { and/or spatial patterns } \\
\text { induced by earthquake } \\
\text { processes }\end{array}$ & $\begin{array}{l}\text { Coseismic to } \\
\text { postseismic, } \\
\text { permanent } \\
\text { to temporary } \\
\text { (possible } \\
\text { subsequent } \\
\text { erosion) }\end{array}$ & 0.1 to $0.2 \mathrm{~g}^{\mathrm{zz}}$ & $\begin{array}{l}\text { Moderate, offshore signatures of } \\
\text { increased sediment fluxes possible. } \\
\text { Stratigraphic 'age inversions' } \\
\text { possible due to liquefaction. }\end{array}$ & $\begin{array}{l}\text { Moderate to low - } \\
\text { patterns of inundation } \\
\text { changes recorded, but } \\
\text { likely to evolve and be } \\
\text { eroded }\end{array}$ & $\begin{array}{l}\text { Possible, although likely } \\
\text { to be highly spatially } \\
\text { variable and ambiguous }\end{array}$ & $\begin{array}{l}\text { No, although } \\
\text { should be a } \\
\text { focus of future } \\
\text { research }\end{array}$ & $\begin{array}{l}\text { No, could relate to changes in } \\
\text { terrestrial hydrology } \\
\text { resulting from climate } \\
\text { change, flooding, river } \\
\text { avulsion, etc. }\end{array}$ & na \\
\hline
\end{tabular}




\begin{tabular}{|c|c|c|c|c|c|c|c|c|c|}
\hline $\begin{array}{l}\text { Shaking-induced } \\
\text { phenomena }\end{array}$ & $\begin{array}{l}\text { Seismic origin of } \\
\text { phenomenon }\end{array}$ & $\begin{array}{l}\text { Temporal } \\
\text { nature of } \\
\text { phenomenon }\end{array}$ & $\begin{array}{l}\text { Minimum } \\
\text { threshold } \\
\text { PGA (g) in } \\
\text { CES }\end{array}$ & $\begin{array}{l}\text { Preservation } \\
\text { potential in } \\
\text { stratigraphic } \\
\text { record }\end{array}$ & $\begin{array}{l}\text { Preservation } \\
\text { potential at } \\
\text { surface }\end{array}$ & $\begin{array}{l}\text { Preservation } \\
\text { potential in biologic, } \\
\text { geochemical, or } \\
\text { hydrologic record }\end{array}$ & $\begin{array}{l}\text { Pre-CES } \\
\text { 'palaeo' } \\
\text { features } \\
\text { identified? }\end{array}$ & $\begin{array}{l}\text { Diagnostic of } \\
\text { seismic origin? }\end{array}$ & $\begin{array}{l}\text { ESI-2007 } \\
\text { metric } \\
\text { (range } \\
\text { of max) }\end{array}$ \\
\hline $\begin{array}{l}\text { 5. Mass } \\
\text { movements: } \\
\text { rockfall and } \\
\text { cliff collapse }\end{array}$ & $\begin{array}{l}\text { Seismic shaking triggers rocks } \\
\text { to detach from bedrock source } \\
\text { areas and move downslope }\end{array}$ & $\begin{array}{l}\text { Coseismic to } \\
\text { postseismic, } \\
\text { permanent }\end{array}$ & $\begin{array}{l}\text { Rockfall }= \\
0.3 \text { to } 0.4 \mathrm{~g} ; \\
\text { cliff collapse }= \\
0.7 \mathrm{~g}\end{array}$ & $\begin{array}{l}\text { High, subsequent burial by hillslope } \\
\text { erosion likely, buried rockfall } \\
\text { deposits identified }\end{array}$ & $\begin{array}{l}\text { High, depends on } \\
\text { possibility of subsequent } \\
\text { burial or erosion or } \\
\text { colluvial processes }\end{array}$ & na & $\begin{array}{l}\text { Yes, buried } \\
\text { and exposed } \\
\text { palaeorockfalls } \\
\text { identified at } \\
\text { sites of } \\
\text { contemporary } \\
\text { rockfall }\end{array}$ & $\begin{array}{l}\text { Somewhat, as deep seated } \\
\text { movements involving large } \\
\text { volumes of material likely } \\
\text { result from earthquakes, } \\
\text { although other possible } \\
\text { triggers such as } \\
\text { meteorological events must } \\
\text { be considered }\end{array}$ & IV-IX \\
\hline $\begin{array}{l}\text { 6. Mass } \\
\text { movements: } \\
\text { landsliding } \\
\text { and loess } \\
\text { cracking }\end{array}$ & $\begin{array}{l}\text { Seismic shaking mass } \\
\text { movements in loessic and } \\
\text { other colluvial deposits, and } \\
\text { bedrock }\end{array}$ & $\begin{array}{l}\text { Coseismic to } \\
\text { postseismic, } \\
\text { permanent } \\
\text { to temporary } \\
\text { (possible } \\
\text { closure of } \\
\text { loess cracks) }\end{array}$ & 0.3 to $0.4 \mathrm{~g}$ & $\begin{array}{l}\text { Moderate, largely size and setting } \\
\text { dependent, strong geomorphic } \\
\text { expression but strong likelihood of } \\
\text { erosion or burial by colluvium of } \\
\text { many features }\end{array}$ & $\begin{array}{l}\text { Moderate, possible } \\
\text { infilling or modification } \\
\text { by other colluvial } \\
\text { processes likely }\end{array}$ & na & $\begin{array}{l}\text { Possible, } \\
\text { palaeo-fissures } \\
\text { identified } \\
\text { elsewhere in } \\
\text { loess, origin } \\
\text { unknown }\end{array}$ & $\begin{array}{l}\text { Somewhat, although possible } \\
\text { climatic, meteorological or } \\
\text { other triggers (vegetation } \\
\text { change, land use change) } \\
\text { must be considered }\end{array}$ & IV-IX \\
\hline $\begin{array}{l}\text { 7. Rock } \\
\text { fragmentation } \\
\text { and summit } \\
\text { boulder } \\
\text { displacement }\end{array}$ & $\begin{array}{l}\text { Seismic shaking causes rocks } \\
\text { to fracture in situ and/or be } \\
\text { detached from underlying } \\
\text { shallow substrate }\end{array}$ & $\begin{array}{l}\text { Coseismic, } \\
\text { permanent }\end{array}$ & 0.4 to $0.6 \mathrm{~g}$ & $\begin{array}{l}\text { High, fractured outcrops infiltrated } \\
\text { with soils likely to be preserved }\end{array}$ & $\begin{array}{l}\text { High, fractures will persist } \\
\text { in rock }\end{array}$ & na & $\begin{array}{l}\text { Possible, } \\
\text { boulders } \\
\text { displaced } \\
\text { pre-CES } \\
\text { identified, } \\
\text { mechanism } \\
\text { unknown }\end{array}$ & $\begin{array}{l}\text { Mostly, although other } \\
\text { processes such as differential } \\
\text { thermal heating, and frost } \\
\text { cracking and heave must be } \\
\text { considered for fracturing and } \\
\text { displacement }\end{array}$ & IX-XI \\
\hline $\begin{array}{l}\text { 8. Groundwater } \\
\text { table changes } \\
(\Delta \geq 0.1 \mathrm{~m})\end{array}$ & $\begin{array}{l}\text { Changes in groundwater level, } \\
\text { storativity, permeability } \\
\text { and/or recharge area due to } \\
\text { seismically induced bedrock } \\
\text { fractures, sediment } \\
\text { compaction and other forms } \\
\text { of nonrecoverable } \\
\text { deformation }\end{array}$ & $\begin{array}{l}\text { Coseismic to } \\
\text { post-seismic, } \\
\text { transient to } \\
\text { permanent }\end{array}$ & $<0.01 \mathrm{~g}$ & $\begin{array}{l}\text { Low, few manifestations of } \\
\text { seismically induced changes in } \\
\text { aquifer properties recognisable and } \\
\text { diagnostic. }\end{array}$ & $\begin{array}{l}\text { Low, however it is } \\
\text { important to consider the } \\
\text { linkages between } \\
\text { sub-surface and surface } \\
\text { hydrological responses to } \\
\text { seismicity. }\end{array}$ & $\begin{array}{l}\text { Low, transient } \\
\text { geochemical responses } \\
\text { are likely in the } \\
\text { short-term; possible } \\
\text { changes in biodiversity } \\
\text { of groundwater } \\
\text { ecosystems. }\end{array}$ & No & $\begin{array}{l}\text { No, groundwater table } \\
\text { fluctuations may be caused } \\
\text { by a variety of other } \\
\text { processes invoked by } \\
\text { climatic, meteorologic, } \\
\text { surface and subsurface } \\
\text { hydrologic, and thermal } \\
\text { changes }\end{array}$ & VII-X \\
\hline $\begin{array}{l}\text { 9. Tree } \\
\text { disturbance }\end{array}$ & $\begin{array}{l}\text { Response to liquefaction, } \\
\text { lateral spreading, surface } \\
\text { subsidence, mass movement, } \\
\text { rock fragmentation, and } \\
\text { groundwater table changes }\end{array}$ & $\begin{array}{l}\text { Coseismic to } \\
\text { postseismic, } \\
\text { permanent } \\
\text { to temporary }\end{array}$ & $0.15 \mathrm{~g}$ & $\begin{array}{l}\text { Possible, if shaking-damaged trees } \\
\text { and roots are preserved at surface } \\
\text { and/or incorporated into } \\
\text { sedimentary record }\end{array}$ & $\begin{array}{l}\text { Moderate, if } \\
\text { shaking-damaged trees } \\
\text { remain in surface } \\
\text { environment and/or leave } \\
\text { geomorphic signal of } \\
\text { disturbance (e.g. } \\
\text { depressions resulting } \\
\text { from uprooting) }\end{array}$ & $\begin{array}{l}\text { Moderate, if } \\
\text { shaking-damaged trees } \\
\text { preserve evidence for } \\
\text { faulting disturbance in } \\
\text { their dendrological } \\
\text { record and/or if new } \\
\text { tree cohorts colonise } \\
\text { fault scarp }\end{array}$ & $\begin{array}{l}\text { No, trees are } \\
\text { too young to } \\
\text { record } \\
\text { penultimate } \\
\text { event }\end{array}$ & $\begin{array}{l}\text { No, tree disturbance also } \\
\text { common due to climatic } \\
\text { variations, weather extremes } \\
\text { (e.g., high winds), and an- } \\
\text { thropogenic factors (e.g. land } \\
\text { cover change) }\end{array}$ & VII-XI \\
\hline
\end{tabular}

zz minimum magnitude-weighted PGA (PGA7.5) at which surface manifestation of liquefaction was observed (see text).

na - not applicable. 
the loose sand sediments with a low liquefaction triggering resistance (Quigley et al., 2013).

The April aftershock $\left(M_{w} 5.0\right.$; Table 1) caused minor localised surface expression of liquefaction (minor and occasional sand blows) at some of the most vulnerable low-lying suburbs adjacent to the lower reaches of the Avon River (Fig. 10C) (Quigley et al., 2013). A $\mathrm{M}_{\mathrm{w}}$ 5.3 earthquake in June caused slightly more extensive localised surface expression of liquefaction in the same areas (i.e., slightly larger and more frequent sand blows) (Fig. 10D) compared to the April $\mathrm{M}_{\mathrm{w}} 5.0$ aftershock (Quigley et al., 2013).

The $M_{w} 6.0$ June and 5.9 December earthquakes also caused widespread and severe surface expressions of liquefaction and liquefactionrelated subsidence despite lower PGA values than the $M_{w} 6.2$ Christchurch earthquake (Fig. 10 E, F). Piezometer measurements following the $\mathrm{M}_{\mathrm{w}} 5.3$ June and $\mathrm{M}_{\mathrm{w}} 5.8$ December earthquakes, $\sim 80 \mathrm{~min}$ in advance of the larger $M_{w} 6.0$ and 5.9 earthquakes respectively, generated excess pore water pressures in the loose to medium density soil layers which did not have the chance to fully dissipate before the subsequent events (Fig. 12), and are likely to have increased the severity of the liquefaction manifestation for the latter earthquakes. In addition, the large subsidence caused by the prior earthquakes, as well of the cracking of the near surface soils particularly in lateral spread areas (namely the $M_{w}$ 7.1 Darfield and $\mathrm{M}_{\mathrm{w}} 6.2$ Christchurch earthquakes), resulted in the groundwater surface being closer to the ground surface, and hence increasing the potential for liquefaction manifestation at the ground surface due to a reduction in the non-liquefying crust thickness (Russell et al., 2015) and compromised cracked crust.

Near the Avon and Heathcote rivers, and also in liquefactionvulnerable areas with topographic elevation differences, lateral spreading was the dominant form of liquefaction manifestation at the ground surface (Figs. 9A, 13). Ground stretching sometimes manifested in cracks, fissures and stretch zones obvious at the ground surface. Cracking was most obvious in areas with stiff non-liquefying soil crusts, but was less obvious in areas with loose or soft non-liquefying soil crusts. Often, non-ductile anthropogenic structures on the ground surface (e.g., buildings, fences, concrete drive ways, kerbs and channels and road pavements) provided the best visual observations of ground stretching resulting from lateral spreading. In most places the cracks formed preferential ejecta pathways for excess water that was expelled (due to the post liquefaction consolidation of the underlying liquefied soil layers), enabling its upward movement towards the ground surface (Fig. 9B) and entrainment of liquefied soil (Fig. 9D). Stiffer and stronger anthropogenic structures on the ground surface (e.g. buildings with concrete slab foundations) often influenced/modified the locations where lateral spreading cracks occurred (typically on either side of the buildings rather than directly beneath the building footprints). In areas away from the rivers most of the liquefaction ejecta emerged in the roadways, predominantly issuing from the bases of street lights and power poles, which rocked back and forth during the earthquake shaking, creating an annulus directly around the base of the poles in the non-liquefying crust and creating preferential ejecta pathways for liquefied material. Reduced shear strength and resistance in liquefied soils caused relative upward 'buoying' transport of manholes and cesspits in many areas.

The horizontal movements caused by lateral spreading and topographic re-levelling were measured manually from displacements across lateral spreading fissures (Cubrinovski et al., 2012) and correlation between pre-CES and post-CES LiDAR and aerial photography pairs. Fig. 13 shows the measured horizontal movements in the eastern suburbs from the correlated pre-CES and post-CES LiDAR pairs with the observed mapped cracks overlaid (Tonkin and Taylor Limited, 2013 and van Ballegooy et al., 2014a), including cracks identified in from detailed field investigations (Bastin et al., 2013a). Displacement vectors reveal that the lateral spreading was not always directed towards the most proximal reach of the modern stream channel, but sometimes in the opposite direction from high elevation to low elevation. An example of this is the western side of anthropogenically-straightened reaches of the Avon River (Fig. 13) where horizontal displacements occurred towards low topography associated with a former water body (Fig. 4) and away from the straightened section of the Avon River, highlighting the importance of palaeochannels and microtopography in influencing lateral spreading and liquefaction manifestation (e.g. Wotherspoon et al., 2012). LiDAR subsidence maps reveal that residential properties (which were built up higher than the roads mainly for managing storm water runoff) typically subsided more than the roads, even though the ejected water sand and silt predominantly came up on the roads. The weight of the built-up properties and the houses squeezed the liquefied soils laterally out from beneath, causing them to settle more, and onto the roadways through the preferential ejecta pathways discussed above, essentially levelling out the land.

Increased sedimentation in parts of the Heathcote-Avon estuary was also observed (Fig. 8F) (Hughes et al., 2015). Surface ejecta was estimated to cover $30-40 \%$ of the estuary surface as sand volcanoes and was mostly coarser grained than the existing estuary surface (Measures et al., 2011) as a result of sediment sorting during the ejection process. This surface ejecta material was subsequently reworked by tidal and wave action (Reid et al., 2012) and is now distributed throughout the estuary.

The widespread occurrence of liquefaction resulted in large volumes of surface ejecta that were typically excavated from residential areas and deposited into landfills (Villemure et al., 2012). Material that was not removed was commonly mobilised via surface and aeolian processes (Quigley et al., 2013) and deposited into urban rivers, estuaries, and offshore. Post-earthquake shallowing of river channels (Fig. 13, panels i-iii) likely reflects combined sedimentation from liquefaction ejecta and lateral spreading-induced inputs to the channel morphology (Hughes et al., 2015).

Subsurface liquefaction features included sand dikes, sills and other types of intrusions, folded and faulted stratigraphy and soil horizons, inclusions of overlying sediments within intrusions, and burial of organic layers that were formerly at the surface (Figs. 9, 14). Liquefaction was most prevalent in Late Holocene alluvial (Wotherspoon et al., 2012; Quigley et al., 2013) and estuarine (Reid et al., 2012) fine-grained sands and coarse-grained silts at depths of $>1.5-5 \mathrm{~m}$. Lateral spreading was most severe within highly liquefiable sediments in low elevation areas ( $\leq 3$ masl) adjacent to modern rivers and estuaries (Fig. 13) (Cubrinovski et al., 2012, 2014; Bastin et al., 2013a, 2013b; Robinson et al., 2014). Differing styles of liquefaction and lateral spreading reflect differences in site conditions (e.g., soil types and distributions, topographic relief and relief distribution, proximity to waterway, elevation, geology, hydrology, sediment age, degree and type of engineered structures) and shaking characteristics (both source and site-induced shaking characteristics, see Fig. 1) (Cubrinovski et al., 2012; Quigley et al., 2013). Inner meander bends (i.e. inner flood plains) of modern rivers and abandoned river channels were particularly vulnerable to liquefaction and lateral spreading (Fig. 13) (Wotherspoon et al., 2012; Cubrinovski et al., 2012; Quigley et al., 2013; Bastin et al., 2013a) due to a combination of unconsolidated fine sand deposits at low $(<2-3$ masl $)$ elevations and perennially shallow (e.g. $<1-2 \mathrm{~m}$ ) water tables adjacent to unconfined stream banks.

Following the $2011 \mathrm{M}_{\mathrm{w}} 6.2$ Christchurch, $\mathrm{M}_{\mathrm{w}} 6.0$ June, and $\mathrm{M}_{\mathrm{w}} 5.9$ December earthquakes, differential InSAR revealed large $\left(>6-10 \mathrm{~km}^{2}\right)$ areas of $\geq 30 \mathrm{~cm}$ displacement (Beavan et al., 2011) indicating combined horizontal and vertical surface displacements resulting from faulting and shaking induced deformation. Differential InSAR following the $M_{w} 6.0$ earthquake revealed areas where combined differential vertical and horizontal movements exceeded $10 \mathrm{~cm}$ (Beavan et al., 2012). Pre- versus post-CES LiDAR differencing (Figs. 8, 11) revealed patterns of CES-induced land elevation changes due to tectonic deformation and liquefaction-induced ground deformation (Hughes et al., 2015). Differential LiDAR showed the $M_{w} 7.1$ Darfield earthquake caused $74 \%$ of central and eastern Christchurch to 

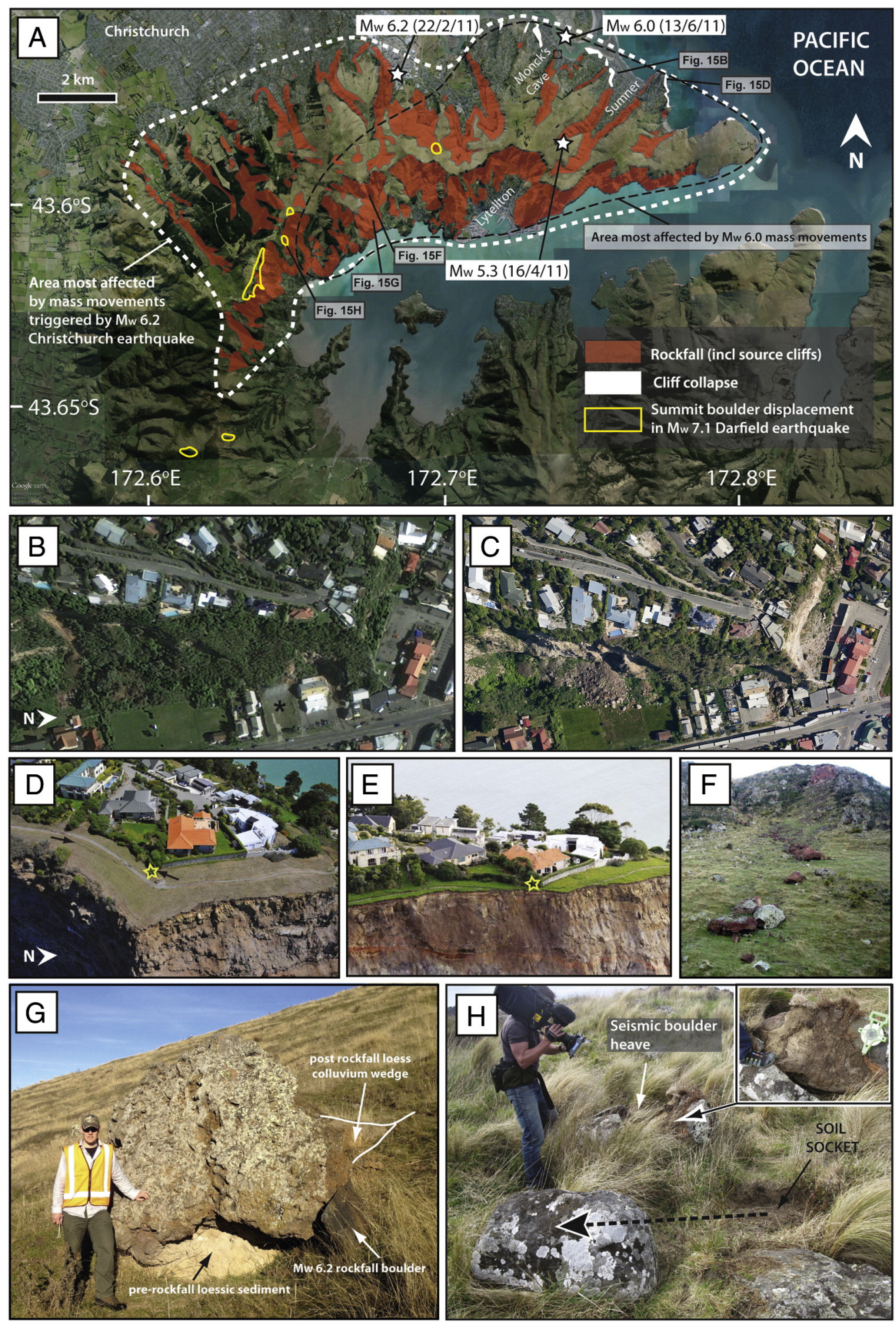

subside; $60 \%$ of this area subsided up to $0.2 \mathrm{~m}$ (Fig. $8 \mathrm{~A}$ ). The $\mathrm{M}_{\mathrm{w}} 6.2$ Christchurch earthquake caused additional subsidence increasing the percentage of eastern and central Christchurch which subsided from $74 \%$ to $83 \%$; $78 \%$ of the area subsided up to $0.3 \mathrm{~m}$ (as a result of the cumulative effect of the $M_{w}$ 7.1 Darfield and $M_{w} 6.2$ Christchurch earthquakes), with localised areas exceeding $1 \mathrm{~m}$. Further subsidence occurred from the June 13, $2011 \mathrm{M}_{\mathrm{w}} 6.0$ and December 23, $2011 \mathrm{M}_{\mathrm{w}}$ $5.8+5.9$ events (Figs. 8,11 ), with a maximum campaign GPS recorded uplift of approximately $10 \mathrm{~cm}$ along the eastern coast of Christchurch in the December 23, $2011 \mathrm{M}_{\mathrm{w}} 5.8+5.9$ earthquakes (Beavan et al., 2012). Cumulative total surface subsidence through the CES, combining tectonic and liquefaction effects, led to subsidence of $86 \%$ of central and eastern Christchurch; $10 \%$ subsided more than $0.5 \mathrm{~m}$, with some localised areas exceeding $1 \mathrm{~m}$ (Figs. 8, 11).

Horizontal ground movements were estimated across the Christchurch city (by correlating LiDAR pairs), and areas adjacent to the 
Avon River experienced severe lateral spreading, particularly on current and former inner meander bends and tidal wetland sediments. Lateral spreading-induced ground fissures of $>1-50 \mathrm{~cm}$ width extended $>100-250 \mathrm{~m}$ inland from adjacent waterways (Cubrinovski et al., 2012; Bastin et al., 2013a). Maximum cumulative lateral ground displacements exceeded 2-3 m (Fig. 13). The density and displacements across fissures typically decreased exponentially with distance from waterways (Fig. 13), although some instances of block-mode failure with highest displacement fissures $>150 \mathrm{~m}$ from the waterway were observed (Cubrinovski et al., 2012; Bastin et al., 2013a). Lateral spreading caused channel-perpendicular shortening locally, accompanied by upward bulging of the river bed across the Avon and Heathcote Rivers (Fig. 13). A comparison of pre-CES and post-13 June 2011 river and floodplain cross sections, derived from a combination of direct river bed depth measurements and LiDAR data, showed floodplain subsidence and river channel narrowing and shallowing resulting from lateral spreading, river channel deformation, and sedimentation from liquefaction ejecta entering waterways (Hughes et al., 2015).

Subsidence exceeding $0.5 \mathrm{~m}$ at the Avon River mouth resulted from combined tectonic down-throw and liquefaction/lateral spread. In other areas, the AHE apparent subsidence of more than $0.5 \mathrm{~m}$ reflects natural migration, widening or deepening of estuarine tidal channels since preCES surveys, and comparable upward movements reflect channel infilling and channel migration.

\subsubsection{Seismic triggering thresholds}

The smallest-magnitude earthquakes to trigger localised surface expression of liquefaction (volumetrically minor and spatially localised sand blows) were the 2010 October 19th $\mathrm{M}_{\mathrm{w}} 4.8$ and 2011 April 16th $\mathrm{M}_{\mathrm{w}} 5.0$ aftershocks. The former caused localised liquefaction in southwest Christchurch (Tonkin and Taylor Limited, 2013) and the latter caused liquefaction in some susceptible sediments with a low liquefaction triggering resistance adjacent to the lower reaches of the Avon River (Fig. 10C; Quigley et al., 2013). The PGA at sites that liquefied in April 16th event is estimated to have been $\sim 0.14$ to $0.16 \mathrm{~g}$ (Fig. 10C). The normalised cone penetration test (CPT) tip resistance $\left(\mathrm{q}_{\mathrm{c} 1 \mathrm{~N}}\right)$ in these areas is typically in the order of 75 to 100 atm over the top 5 to $10 \mathrm{~m}$ of the soil profile, characteristic of loose sands. Using the Boulanger and Idriss (2014) relationship (which estimates $\mathrm{PGA}_{7.5}$ as a function of both magnitude and soil density inferred from $\mathrm{q}_{\mathrm{c} 1 \mathrm{~N}}$ ), the equivalent $\mathrm{PGA}_{7.5}$ for liquefaction assessment purposes in these areas is estimated as 0.11 to $0.13 \mathrm{~g}$. Slightly more extensive surface expression of liquefaction (i.e., slightly larger and more frequent sand blows) was manifested in these areas following the $M_{w} 5.3$ June 13th earthquake (Fig. 10D). The PGA in these areas is estimated to have been approximately 0.20 to $0.24 \mathrm{~g}$, which equates to $\mathrm{PGA}_{7.5}$ ranging between 0.16 and $0.20 \mathrm{~g}$. More extensive and severe surface expression of liquefaction (i.e., large and frequent sand blows) was manifested in these areas following the $M_{w}$ 7.1 Darfield earthquake (Fig. 10A). The PGA in these areas is estimated to have been approximately 0.18 to $0.20 \mathrm{~g}$, which equates to $\mathrm{PGA}_{7.5}$ ranging between 0.17 and $0.19 \mathrm{~g}$. The most severe surface expression of liquefaction (i.e., large and frequent sand blows such that the streets and properties were extensively covered with 100 to $300 \mathrm{~mm}$ of ejected liquefied material; e.g. Fig. 9D) were manifested in these areas in the $M_{w} 6.2$ Christchurch earthquake. The PGA in these areas is estimated to have been approximately 0.40 to $0.60 \mathrm{~g}$ (Fig. 10B), which equates to $\mathrm{PGA}_{7.5}$ ranging between 0.36 and $0.54 \mathrm{~g}$. Whilst the $\mathrm{M}_{\mathrm{w}} 6.0$ (Fig. 10E) and 5.9 (Fig. 10F) earthquakes also manifested severe surface expressions of liquefaction (similar to the surface expression following the $\mathrm{M}_{\mathrm{w}} 6.2$ Christchurch earthquake) at lower $\mathrm{PGA}_{7.5}$ values, the influence of the preceding June and December earthquakes $\left(\mathrm{M}_{\mathrm{w}} 5.3\right.$ and 5.8 respectively) $\sim 80$ min before the larger earthquakes, and the cumulative subsidence caused by the $\mathrm{M}_{\mathrm{w}} 7.1$ Darfield and $\mathrm{M}_{\mathrm{w}} 6.2$ Christchurch earthquakes, is likely to have increased the severity of the liquefaction manifestation for the latter earthquakes by (i) temporarily elevating pore fluid pressures (Fig. 12), (ii) permanently changing pore fluid pressures, and (iii) creating fracture pathways through the non-liquefying cap sediment that enabled subsequent events to more easily inject through this sediment to the surface (Quigley et al., 2013).

In eastern Christchurch further away from the Avon River where the soil profiles comprise medium dense to dense sands, typified by CPT $\mathrm{q}_{\mathrm{c} 1 \mathrm{~N}}$ in the order of 125 to $175 \mathrm{~atm}$ over the top 5 to $10 \mathrm{~m}$ of the soil profile, no surface expression of liquefaction was observed following the April aftershock, and the June $\mathrm{M}_{\mathrm{w}} 5.3$ and $\mathrm{M}_{\mathrm{w}}$ 7.1 Darfield earthquakes. The maximum PGA $_{7.5}$ for which no surface expression of liquefaction was observed was $0.16 \mathrm{~g}$ in these areas for these events. Following the $M_{w} 6.2$ Christchurch earthquake, moderate surface expressions of liquefaction (moderate size sand blows at relative frequent spacing) were manifested at a $\mathrm{PGA}_{7.5}$ of 0.2 to $0.35 \mathrm{~g}$.

Based on the above, sand blow formation in areas with loose sandy soils (typified by CPT $\mathrm{q}_{\mathrm{c} 1 \mathrm{~N}}$ values ranging between 75 and $100 \mathrm{~atm}$ over the top 5 to $10 \mathrm{~m}$ of the soil profile) appears to be triggered at a PGA 7.5 of greater than $0.11 \mathrm{~g}$. This is consistent with CPT-based liquefaction consequence studies undertaken by Lacrosse et al. (2015) and Leeves et al. (2015), which show that predicted liquefaction consequence is first triggered for $\mathrm{M}_{\mathrm{w}} 6.0$ events with a PGA of around $0.11 \mathrm{~g}$, for loose clean sand soils with $\mathrm{q}_{\mathrm{c} 1 \mathrm{~N}}=80 \mathrm{~atm}$, which is equivalent to a $\mathrm{PGA}_{7.5}$ value of $0.09 \mathrm{~g}$. Uncertainties in magnitude scaling factors used to estimate $\mathrm{PGA}_{7.5}$ from PGA may best explain the lowest ever reported liquefaction-triggering PGA $_{7.5}$ values of $0.06 \mathrm{~g}$ from a particularly vulnerable location in eastern Christchurch (Quigley et al., 2013).

Sand blow formation in areas with medium dense to dense sandy soils (typified by CPT $\mathrm{q}_{\mathrm{c} 1 \mathrm{~N}}$ values ranging between 125 and $175 \mathrm{~atm}$ over the top 5 to $10 \mathrm{~m}$ of the soil profile) appears to be triggered at a $\mathrm{PGA}_{7.5}$ somewhere between 0.16 and $0.2 \mathrm{~g}$. Again this is consistent with CPT-based liquefaction consequence studies undertaken by Lacrosse et al. (2015) and Leeves et al. (2015) which both show that

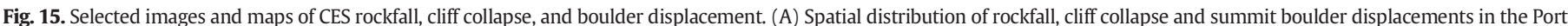

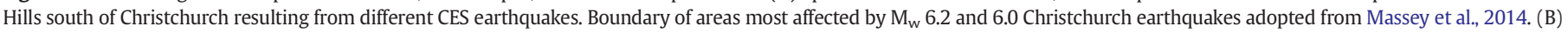

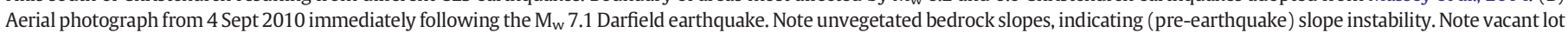

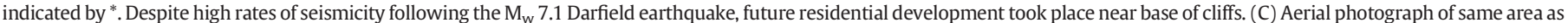

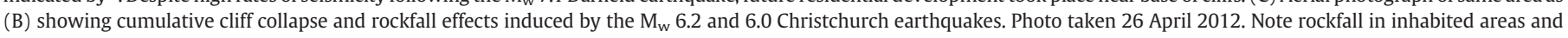

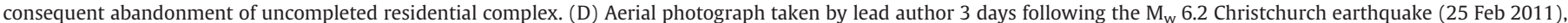

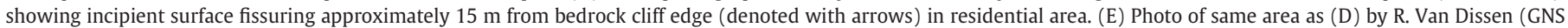

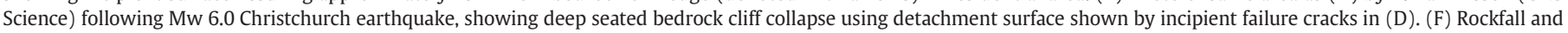

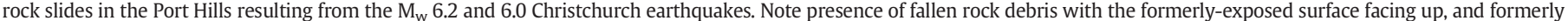

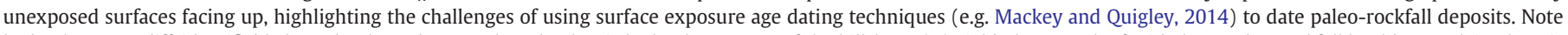

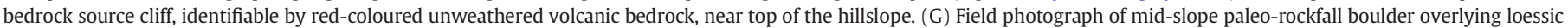

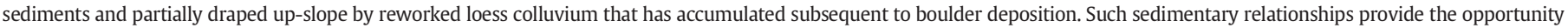

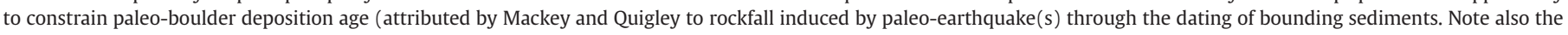

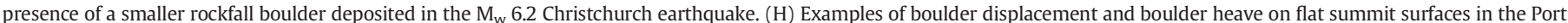

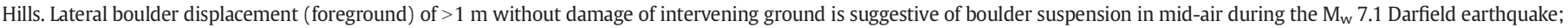

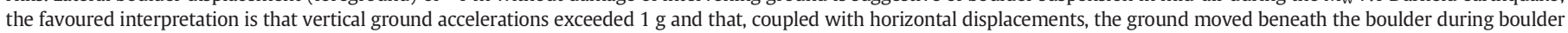
suspension resulting in finite boulder translation with respect to the ground surface. Boulders were not displaced in following earthquakes. 


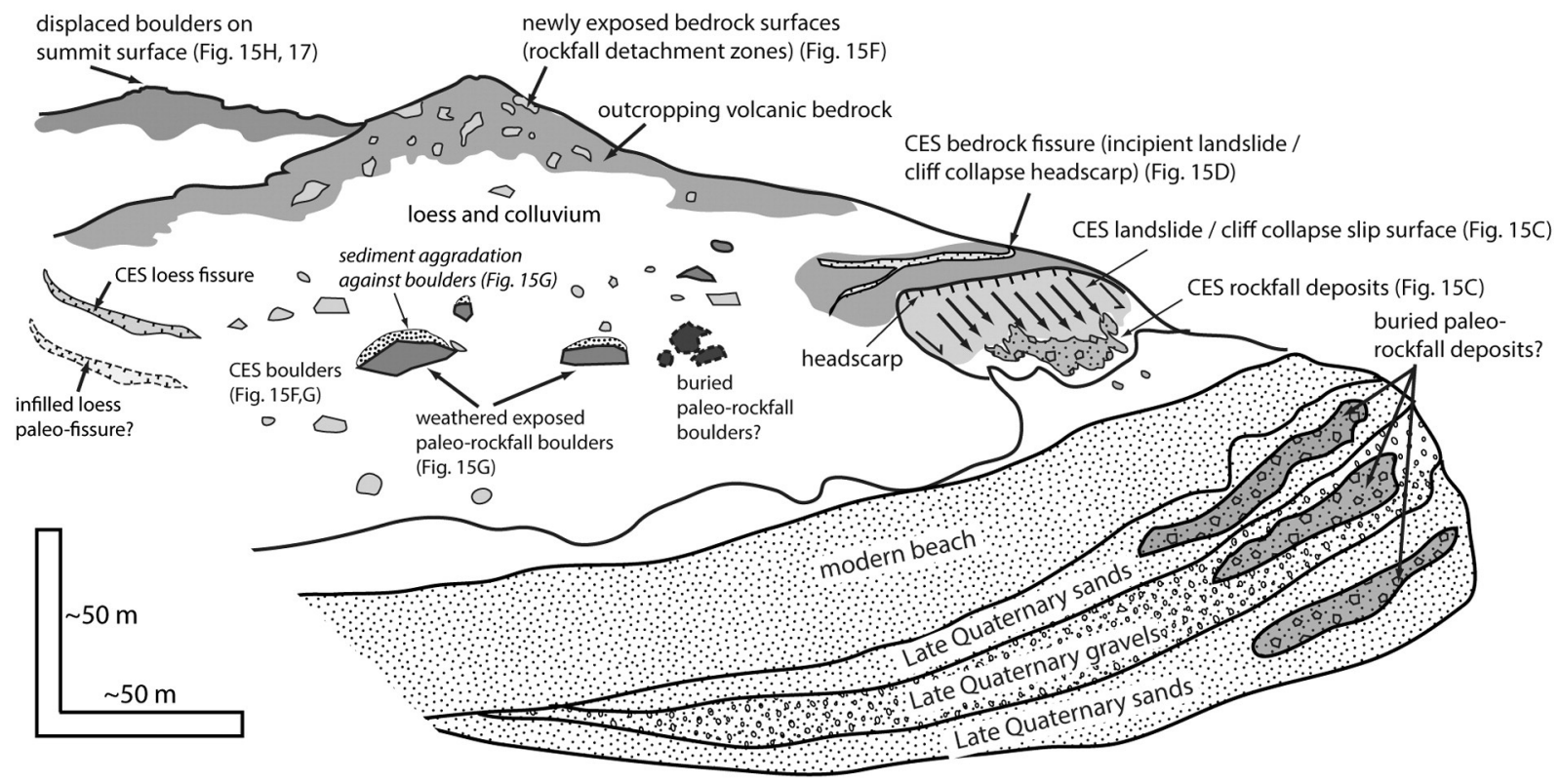

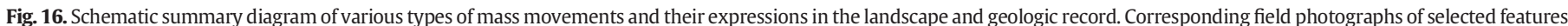
appear in Figs. 15 and 17.

predicted liquefaction consequence is first triggered for $M_{w} 6.0$ events with a PGA of $0.25 \mathrm{~g}$, for loose sandy soils with $\mathrm{q}_{\mathrm{c} 1 \mathrm{~N}}=120 \mathrm{~atm}$, which is equivalent to a $\mathrm{PGA}_{7.5}$ value of $0.2 \mathrm{~g}$. The sand blow areal extents and thicknesses in areas with the same soil density scale with $\mathrm{PGA}_{7.5}$, as also shown by Quigley et al. (2013).
Alignments of sand blows interpreted to indicate coeval lateralspreading at depth (Quigley et al., 2013) were formed in earthquakes as small as $\mathrm{M}_{\mathrm{w}} 5.3$ (Table 1) with $\mathrm{PGA}_{7.5}$ of $\geq 0.16 \mathrm{~g}$ (Fig. 10D). We thus infer a creation threshold for lateral spreading initiation in susceptible natural sediments with a low liquefaction triggering resistance
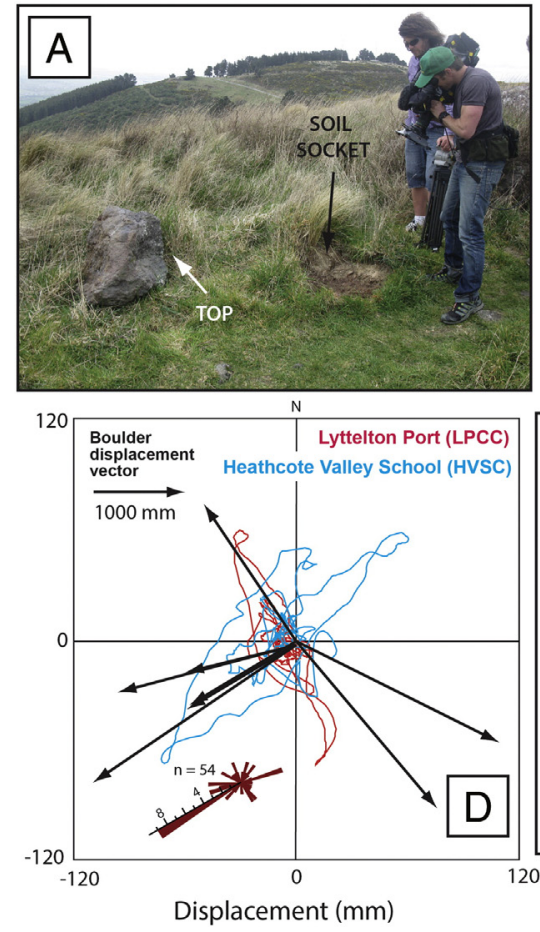

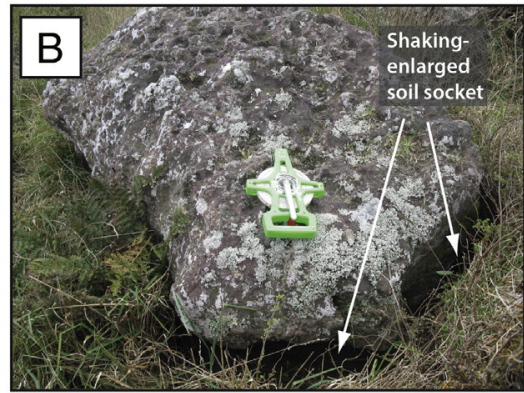

1. NEWLY EXPOSED BEDROCK SURFACE 2. BURIAL OF WEATHERED BEDROCK SURFACE 3. NEW LICHEN GROWTH 4. LICHEN DIE-OFF ROTATED / DISPLACED BOULDER

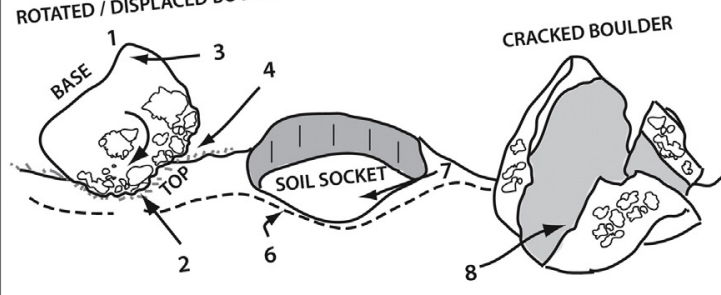

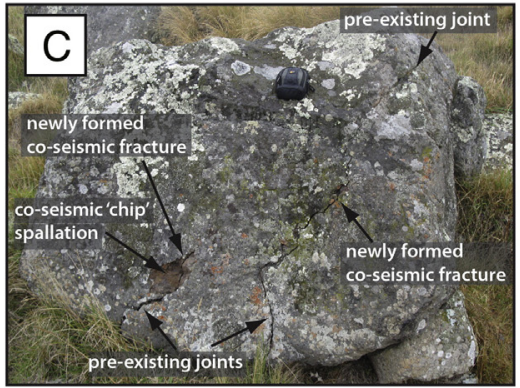

5. BURIED ORGANICS AND NEWLY SHIELDED SEDIMENT 6. THINNED SOIL PROFILE 7. SEDIMENT INFILLING INTO BOULDER SOCKET
8. SURFACE SEDIMENT INFILTRATION INTO CRACKED BOULDER SEIMENT INFILTRATION INTO SHAKING-ENLARGED SOIL SOCKET 9. SURFACE SEDIMENT INFILTRATION
CRACKED BOULDER

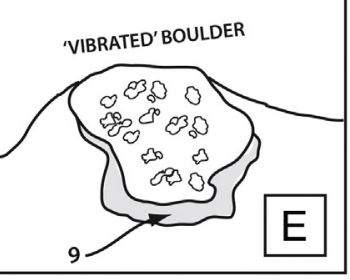

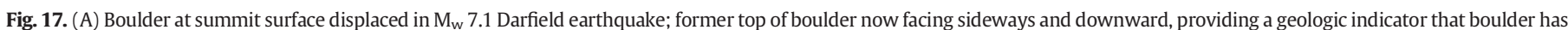

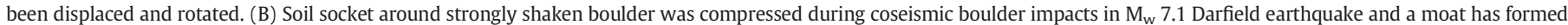

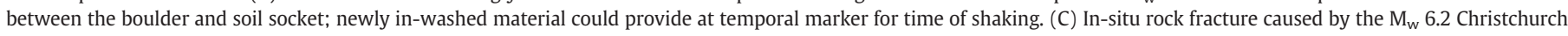

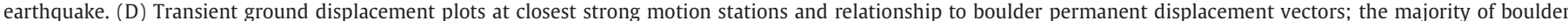

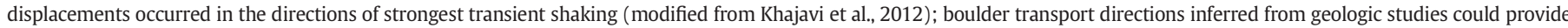

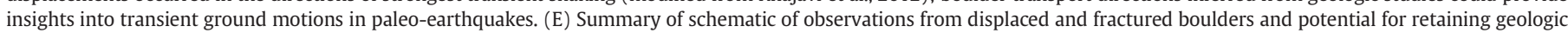
information pertinent to paleoseismic studies. 

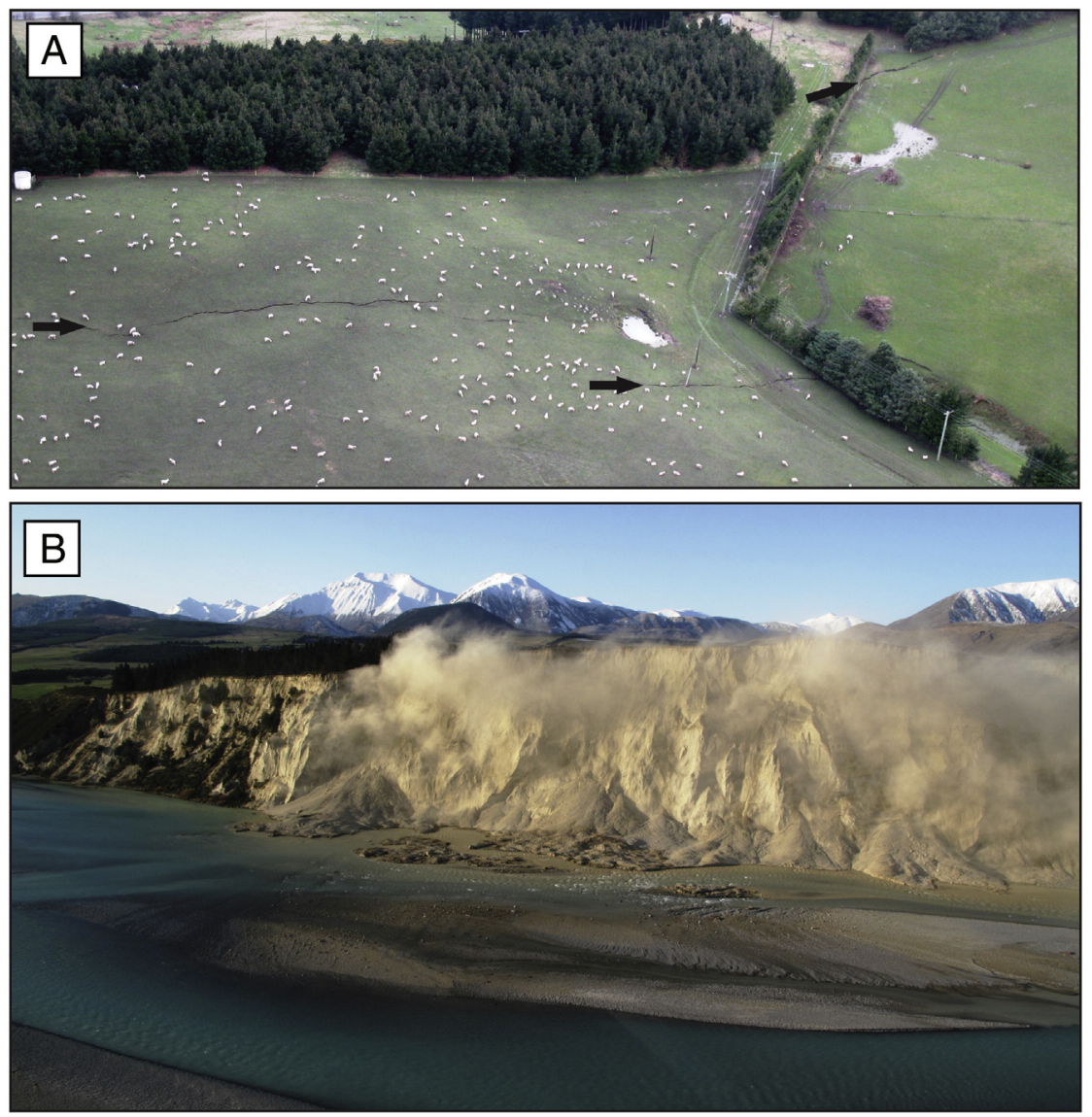

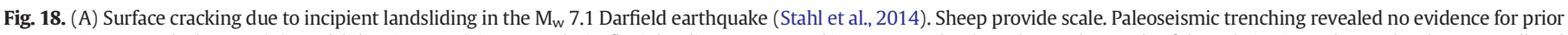

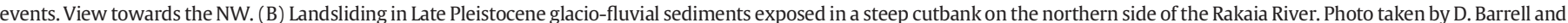

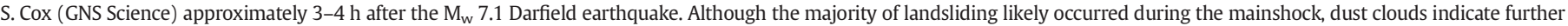
slope failure in aftershocks. View towards the NW.

(Table 2B) of this value, whilst acknowledging that variations in soil stratigraphy and origin (e.g. natural versus manmade hydraulic fills) can exert strong influence on lateral spreading initiation thresholds and manifestations. We adopt a slightly higher PGA threshold for lateral spreading than liquefaction because we acknowledge that localised domains of liquefaction could be initiated at lower PGA without the subsurface 'connectivity' required to induce larger-scale spreading and flow in the overlying crust.

The extensive liquefaction induced in and around Christchurch during the CES is hypothesised by Cox et al. (2012) to represent fluid release from confined aquifers in response to dynamic stressing. The degree to which this mechanism has controlled the extent and severity of liquefaction, as opposed to other mechanisms such as sediment consolidation, is an important and unresolved question that relates directly to the issue of how liquefaction hazards might be mitigated in Christchurch and elsewhere.

Similarly, research into 'soil ageing', suggests that mechanical and chemical processes that take place following the sedimentation of sand deposits results in a logarithmic increase in the soil strength and liquefaction triggering resistance over time (Leon et al., 2006 and Hayati and Andrus, 2009 amongst others). The published literature suggests that liquefaction triggering resets the soil ageing clock back to zero in the liquefied soil layers (Leon et al., 2006 and Maurer et al., 2014c), with the fastest increase in soil strength and resistance to liquefaction triggering occurring in the first few months following the causative earthquakes. This may also have affected the liquefaction triggering thresholds for the smaller October 2010 and April 2011 aftershock events.

\subsubsection{Palaeoseismic implications}

Evidence for palaeoliquefaction in shallow (1-2 m depth) trenches has been documented at several sites in eastern Christchurch where CES liquefaction occurred (Bastin et al., 2015, in review; Quigley et al., 2013; Villamor et al., 2014, 2016). Palaeoliquefaction features including feeder dikes, sills, bulbous intrusions, lateral spreading cracks, and subsurface sand blows analogous to CES features have been observed (Figs. 9, 14). Palaeo-feeder dikes are variably reactivated and/or crosscut by CES intrusions (Fig. 9B). Palaeoliquefaction features are typically observed to cross-cut mid to late Holocene sediments and are heavily mottled by oxidation weathering (Fig. 9C), implying genesis during late Holocene earthquakes or possibly historical earthquakes. In late Holocene sediments in eastern Christchurch, the maximum width of feeder dikes and sills formed during the $\mathrm{M}_{\mathrm{w}}$ 6.2 Christchurch and 6.0 June earthquakes exceeds that of any identified palaeoliquefaction dikes, suggesting that the liquefaction and lateral spreading incurred in these events earthquakes were the most severe to have occurred during the Late Holocene. Consistent with this interpretation, subsurface investigations of susceptible Late Holocene sediments with a low liquefaction triggering resistance in southern Christchurch, where liquefaction was limited to the $M_{w} 6.2$ and 6.0 Christchurch earthquakes, found no evidence for preceding palaeo-liquefaction features (Grace, in review).

Preliminary evidence suggests liquefaction-inducing palaeoearthquakes occurred between A.D. 1000 and A.D. 1400 in southwest Christchurch (Villamor et al., 2014, 2016) and after AD 1660 to 1800 and before ca. 1905 in eastern Christchurch (Bastin et al., 2015). The origin of the liquefaction-inducing earthquakes is unknown, however 
the ca. AD 1000-1400 palaeoliquefaction event(s) overlap temporally with large earthquakes on the Alpine (ca. 1400-1450 A.D.; Sutherland et al., 2007) and Porters Pass Faults (ca. 1400-1500 A.D.; Howard et al., 2005). Both of these faults are expected to have caused strong ground motions in Christchurch of sufficient PGA to have induced liquefaction in susceptible sediments with a low liquefaction triggering resistance, based on $\mathrm{M}_{\mathrm{w}}$ bound curves (Maurer et al., 2015) and ground motion prediction equations (Bradley, 2013a, 2013b; used in Bastin et al., 2015). The Alpine Fault earthquake at ca. 1717 (Sutherland et al., 2007) is a permissible trigger for eastern Christchurch palaeoliquefaction based on temporal grounds. Of the historical earthquakes, the $1869 \mathrm{M}_{\mathrm{w}} \sim 4.8$ Christchurch earthquake is estimated to be the most likely to have generated local $\mathrm{PGA}_{7.5}$ sufficient to trigger liquefaction in the susceptible sediments with a low liquefaction triggering resistance (Bastin et al., 2015), but not sufficiently pervasive to result in manifestation at the ground surface. Prehistoric earthquakes from other mapped and unknown faults throughout the region, including local blind faults, provide alternative possible sources for the identified palaeoliquefaction features. $M_{w}$-bound curves suggest that $M_{w} \geq 6,7$, and 8 events within 12,35, and $100 \mathrm{~km}$ of the eastern Christchurch study site have liquefaction-inducing probabilities exceeding $50 \%$ (Maurer et al., 2015). The penultimate earthquake on the source of the $\mathrm{M}_{\mathrm{w}} 7.1$ Darfield earthquake (Greendale Fault) occurred ca. 20$30 \mathrm{kyr}$ ago (Hornblow et al., 2014) and rock fall evidence suggests that no large earthquakes have occurred on the local faults responsible for the $M_{w} 6.2$ Christchurch and 6.0 June earthquakes within the last 6000 to 8000 years (Mackey and Quigley, 2014), indicating that the CES sources were not responsible for the palaeoliquefaction.

Monitoring of liquefaction surface ejecta features produced in CES events indicates that sand blow surfaces in some settings rapidly (e.g. within days to months) evolved into rippled dune-like forms, commonly with micro-rills and micro-channels that would be difficult to distinguish from aeolian or alluvial features (Quigley et al., 2013). Tidal fluctuations removed other evidence, for example in the AHE, where sand blows were removed rapidly by marine erosion (Reid et al., 2012). However, in some instances, flooding, burial or floral colonisation may enable sand blows to persist in the geologic record in the absence of anthropogenic modification. For example, sand blows on tidal flats along the lower Heathcote River have been preferentially colonised by Sacracornia plants that inhibit erosion, resulting in preservation of sand blow geometries (Bastin et al., 2013b), and vent zones for AHE sand blows have been preserved (see below). Buried palaeo sand blows have been recently identified in Kaiapoi (Bastin et al., in review).

In both terrestrial and marine environments, feeder dikes retained pristine geometries in the shallow subsurface (Quigley et al., 2013; Reid et al., 2012). Although in some instances multiple generations of CES dikes were identifiable (Fig. 9B), in other cases only two generations of feeder dike were revealed from cross-cutting relationships at a site that experienced at least eight distinct venting episodes, implying that repeated dike re-activation in successive liquefaction episodes removed evidence of prior events (Quigley et al., 2013). Quigley et al. (2013) cautioned that discernible, individual liquefaction feeder dikes should be thus treated as providing a minimum estimate of the number of temporally distinct liquefaction-inducing earthquakes in both modern and palaeo-liquefaction investigations (e.g., Sims and Garvin, 1995). Relative changes in sand blow thickness and areal extent at individual sites are argued to have the potential to provide information on the relative site-specific shaking intensities of successive liquefaction-inducing earthquakes (Quigley et al., 2013).

5.5. Mass movements: rockfall, cliff collapse, landsliding, boulder displacements and rock fragmentation

\subsubsection{Effects and distribution}

Mass movements during the CES (Figs. 15-18) included (i) detachment of isolated rocks from bedrock outcrops or sediments on steep slopes that subsequently rolled or bounced downslope along ballistic trajectories (i.e. rockfall, boulder roll), (ii) the detachment and gravitational collapse of large masses $\left(>10^{2}\right.$ to $10^{4} \mathrm{~m}^{3}$ ) of bedrock material from steep cliffs (i.e. cliff collapse, debris avalanches), (iii) soil slumps and avalanches primarily involving Quaternary to Recent sediments, (iv) loess fissures, (v) detachment of rocks from bedrock outcrops or sediments and displacement across low-relief surfaces such as summit crests (i.e. displaced boulders) and (vi) small-scale in situ rock fragmentation and rock chip spallation. Geologic and geomorphic properties such as lithology, structure, soil type and slope influenced the manifestation of these phenomena.

Distinct episodes of rockfall in the Port Hills and other areas of Banks Peninsula occurred in the $M_{w}$ 7.1 Darfield, $M_{w} 6.2$ Christchurch, $M_{w} 5.3$ April, $M_{w} 6.0$ June and $M_{w} 5.8$ and 5.9 December earthquakes (Table S1; Fig. 15A) (Massey et al., 2014). Rockfalls involved the detachment of individual boulders ranging in volume from $<0.3 \mathrm{~m}^{3}$ to $>10 \mathrm{~m}^{3}$ from subvertical to steeply inclined bedrock outcrops and loess slopes and subsequent downslope displacement. The slope of rockfall source areas typically exceeds $35^{\circ}$, with most boulders derived from slopes $>45^{\circ}$ (Massey et al., 2014). Boulder frequency-volume relationships fit a power law at volumes $>0.3 \mathrm{~m}^{3}$ (Massey et al., 2014; Borella et al., in review). Individual boulders travelled distances of $<100 \mathrm{~m}$ to $>700 \mathrm{~m}$ from source cliffs. Topographic metrics showed correlations between boulder runout distance, hillslope angle (e.g., shadow angle) and hillsope shape (planar versus curved versus stepped) (Massey et al., 2014; Heron et al., 2014).

Rockfalls in the $\mathrm{M}_{\mathrm{w}} 6.2$ Christchurch earthquake had the largest spatial extent ( $\sim 65 \mathrm{~km}^{2}$; Table S1; Fig. 15A), and largest number of fallen rocks ( $>5700$ in residential areas) as reported by Massey et al. (2014). The June $M_{w} 6.0$ earthquake was the next largest event in terms of spatial extent (Fig. 15A) and rockfall flux. Rockfalls during the $M_{w}$ 7.1 Darfield, $M_{w}$ 5.3 April, and $M_{w} 5.8$ and 5.9 December events were limited to particularly susceptible source cliffs. Isolated rockfall was reported at coastal cliffs on eastern Banks Peninsula and along the eastern coast of Pegasus Bay at epicentral distances of $\geq 80 \mathrm{~km}$ in the $M_{w}$ 7.1 Darfield earthquake. In this instance the largest $M_{w}$ earthquake was associated with the largest recorded distance from epicentre to most distal rockfall, however this earthquake had a relatively low rockfall flux and density compared to the $\mathrm{M}_{\mathrm{w}} 6.2$ and 6.0 Christchurch earthquakes. Highly localised rockfall also occurred in the absence of coseismic triggering, for example a debris flow in March 2014 during a high rainfall event deposited hundreds of rocks downslope. Isolated rockfall may also have occurred in the absence of direct observation or documentation during other earthquakes with lower shaking intensities.

Major cliff collapse and related cliff top recession occurred in the $\mathrm{M}_{\mathrm{w}}$ 6.2 Christchurch and $\mathrm{M}_{\mathrm{w}}$ 6.0 June earthquakes (Table S1; Fig. 15B-E) (Massey et al., 2014). The April earthquake also triggered a spatially localised but large recession event (Table S1). Minor cliff recession due to spalling rocks from cliff faces occurred in the December earthquakes. Following the $M_{w} 6.2$ Christchurch earthquake, a series of bedrock fissures were identified from helicopter reconnaissance and field mapping on the tops of some bedrock ridges (Fig. 15D). Several of these fissures subsequently failed during the June $M_{w} 6.0$ earthquake (Fig. 15E), implying that the fissures marked sites of incipient bedrock failure zones prone to future cliff recession. Talus sourced from cliff collapse inundated flat-lying areas at the base of collapsed cliffs, forming sloping rockfall deposits (Figs. 15C, 16).

Shallow landslides including soil slumps occurred at some places in the Port Hills, primarily during the $\mathrm{M}_{\mathrm{w}} 6.2$ and 6.0 Christchurch earthquakes. Such features reflect a frequent geomorphic process in this area as indicated from both historic and prehistoric evidence (Della Pasqua et al., 2014).

Fissures extending several 100s of metres in length formed in loess and loess colluvium mantles resting on volcanic bedrock (StephenBrownie, 2012). Fissure orientations typically paralleled topographic 
contours, suggesting an origin related to gravitational failure. Fissures were commonly associated with topographic bulges interpreted as compression and extension features, and variably associated with springs, tunnel gulleys, lateral spreads, toppling, and bedrock fractures. In contrast with the bedrock fissures described above, incipient landsliding was considered the least likely of possible mechanisms for generating loess fissures (Stephen-Brownie, 2012).

Boulders ranging from 10 to $1000 \mathrm{~kg}$ in mass were displaced distances of $>0.1$ to $2 \mathrm{~m}$ from shallow $(<50 \mathrm{~cm})$ soil sockets on low angle slopes $\left(<10-15^{\circ}\right.$ ) on summit surfaces during the $M_{w} 7.1$ Darfield earthquake (Khajavi et al., 2012) (Fig. 15H). The majority of boulder displacement vectors were oriented subparallel to maximum instrumentally recorded peak ground displacements from proximal seismometers (Fig. 17D) (Khajavi et al., 2012). Some large displaced boulders showed no evidence for rotation and the ground between the boulder and source socket was undamaged, suggesting that the boulders were temporarily airborne during transient strong ground shaking with vertical PGAs exceeding $1 \mathrm{~g}$ due to topographic amplification along ridge crests. Other phenomena included boulder heave (Fig. 15H), boulder throw (Fig. 17A) and enlargement of soil sockets by shaking-induced boulder impacts (Fig. 17B). Re-examination of the same boulders following the $\mathrm{M}_{\mathrm{w}} 6.2$ Christchurch and 6.0 June aftershocks indicated no further displacement.

Evidence for in situ rock fragmentation was locally observed only following the $M_{w} 6.2$ Christchurch earthquake. Fresh cracks propagated between existing joints (Fig. 17C). Small rock chips were locally spalled from boulder surfaces.

Curvilinear fissures ranging from $<20$ to $\sim 150 \mathrm{~m}$ in length with net displacements of $\sim 5-40 \mathrm{~cm}$ (Fig. 18A) were observed in a moderate $(\sim 180-200 \mathrm{~m})$ relief hillslope underlain by sandstones, volcanics, and beidellite-montmorillonite-bentonite units following the $\mathrm{M}_{\mathrm{w}} 7.1$
Darfield earthquake (Stahl et al., 2014). Stahl et al. (2014) attributed these features to bedding-controlled translation and joint-controlled toppling in incipient deep-seated movement.

\subsubsection{Seismic thresholds}

Massey et al. (2014) compared rockfall observations with ground motion data obtained from nearby seismometers to infer a rockfall triggering horizontal PGA threshold of $0.3 \pm 0.1 \mathrm{~g}$. This triggering threshold was defined as the transition from 'minimal' rockfalls to 'spatially limited' and 'localised' rockfalls. A horizontal PGA threshold of $\sim 1.0 \mathrm{~g}$ was interpreted to represent the transition to the extensive and severe rockfalls that occurred during the $\mathrm{M}_{\mathrm{w}} 6.2$ Christchurch earthquake. Horizontal PGA was used by these authors as the measure of ground shaking on the assumption that rockfalls require an instantaneous force exceeding some critical value to trigger them. Measured PGAs were not used to conduct site-specific dynamic analysis of the rockfall triggering because no PGA measurements were obtained directly at rockfall source sites. Topographic and geometric effects may have amplified horizontal PGAs by $>30-80 \%$ (Khajavi et al., 2012; c.f. Beuch et al., 2010), implying that the instrumentally recorded PGAs may under-estimate rockfall triggering PGAs at the source cliffs. Topographic and lithologic variability is likely to have introduced significant complexity in ground motion amplification and polarisation over small distances and at different frequencies at some sites of mass movements (Kaiser et al., 2013).

Mackey and Quigley (2014) used horizontal peak ground velocity $\left(\mathrm{PGV}_{\mathrm{H}}\right)$ to characterise rockfall-triggering strong ground motions at a single study site. PGV was used on the basis that it is directly proportional to the kinetic energy required to induce rockfall (Andrews et al., 2007; Rathje et al., 2013) and that PGAs can often be very high in frequency, such that the momentum transferred to the potentially unstable rocks

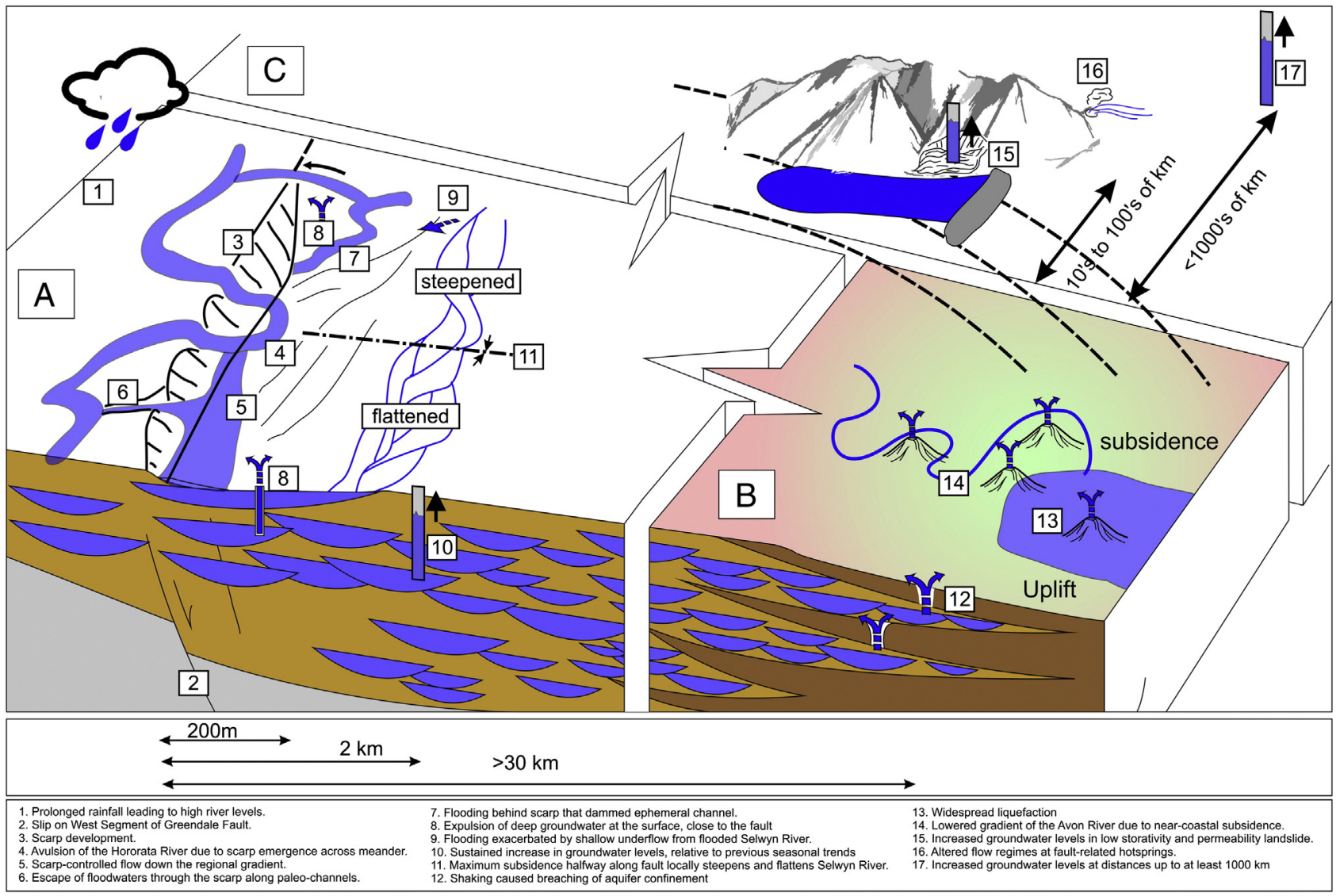

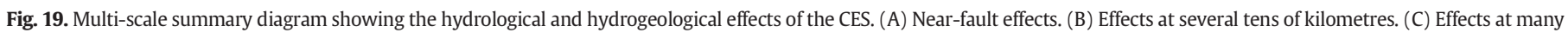
tens to several hundreds of kilometres. 

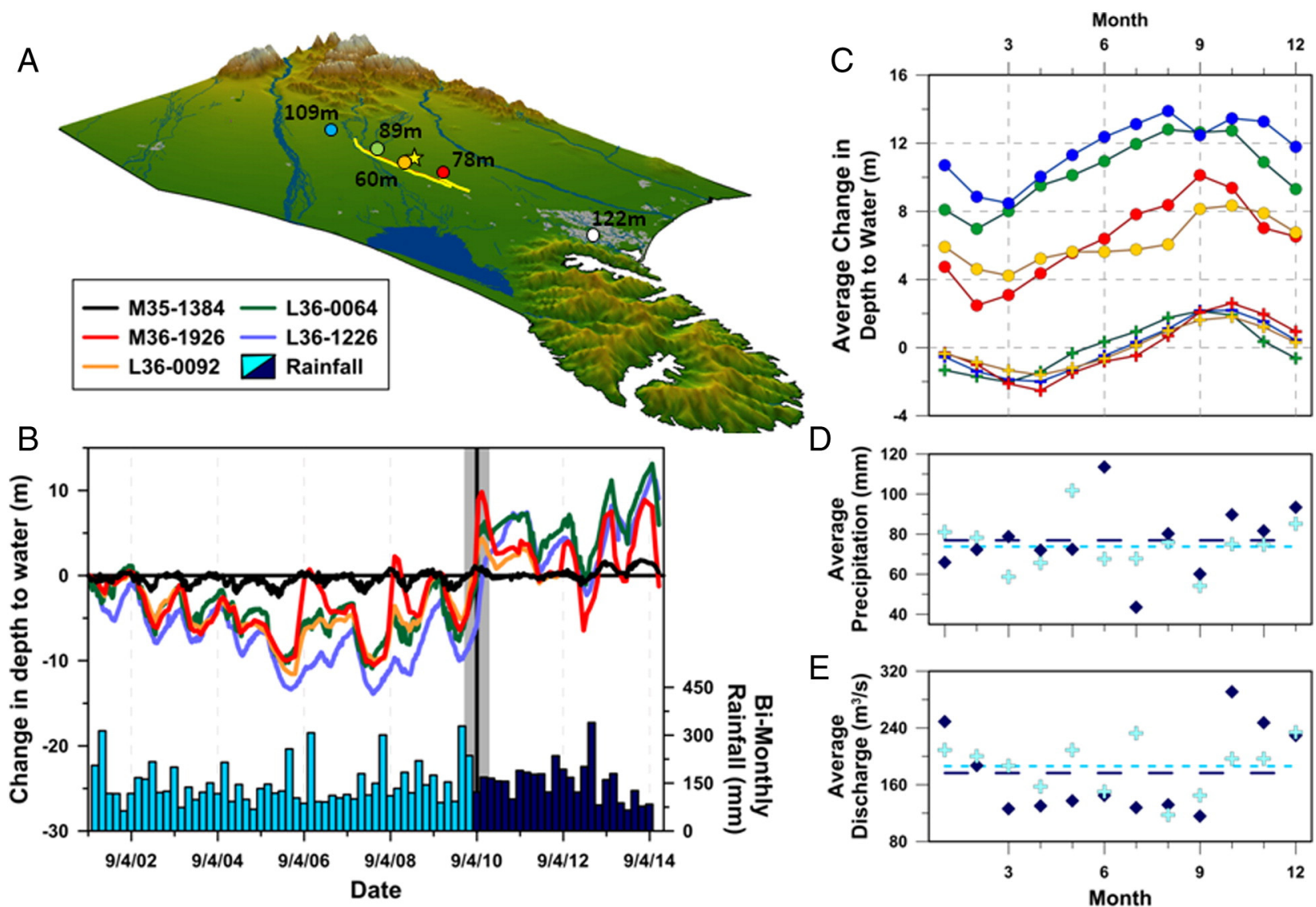

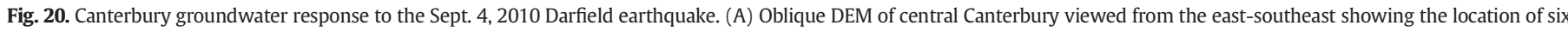

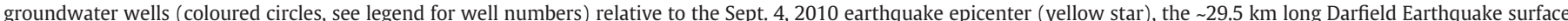

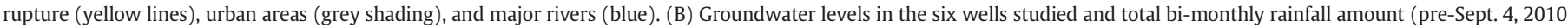

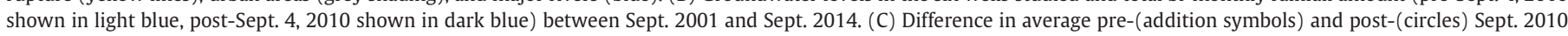

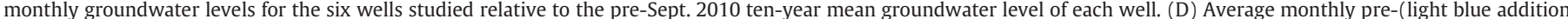

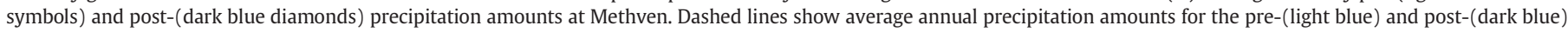

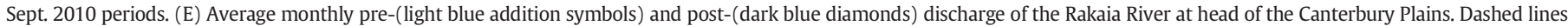
show average annual discharge for the pre-(light blue) and post-(dark blue) Sept. 2010 periods.

can vary widely. $\mathrm{PGV}_{\mathrm{H}}$ was estimated for a rockfall source cliff for the strongest CES earthquakes using linear interpolation between nearby seismometers where PGVs were instrumentally recorded. Some of the seismometers were located in bedrock at elevations similar to the study site, thereby partially accounting for some of the effects of topographic amplification. A rockfall triggering threshold of $\mathrm{PGV}_{\mathrm{H}}=12 \pm 1 \mathrm{~cm} \mathrm{~s}^{-1}$ was determined for the localised detachment of susceptible rocks in a previously fractured rock mass, $\mathrm{PGV}_{\mathrm{H}}=17 \pm 2 \mathrm{~cm} \mathrm{~s}^{-1}$ for localised rock fracture and rockfall in an intact rock mass, and $\mathrm{PGV}_{\mathrm{H}} \geq 25-30 \mathrm{~cm} \mathrm{~s}^{-1}$ 1 for extensive rockfall and rock mass fracturing.

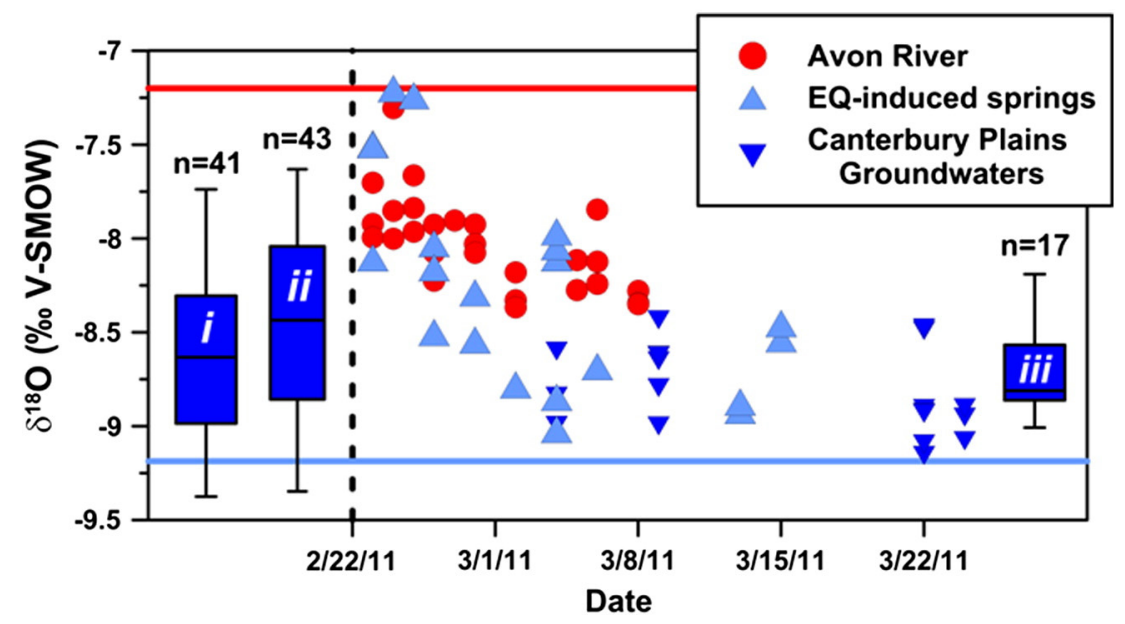

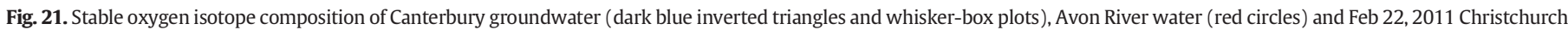

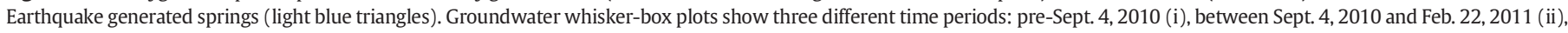

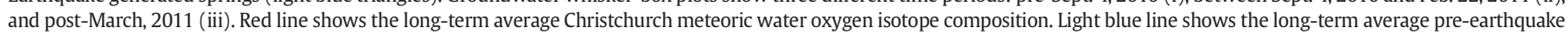
Waimakariri River water oxygen isotope composition. 
These two studies show higher PGA and PGVs resulted in increased rockfall densities at individual sites and increased areal extent of rockfalls of given density (e.g. $>1-10$ boulders per $100 \mathrm{~m}^{2}$ ) throughout the Port Hills. It is clear that strong earthquakes, in addition to liberating loose rocks from source cliffs, caused further bedrock fracturing and rock mass dilatation in source cliffs, resulting in a 'conveyor belt' style mechanism of rockfall generation.

In general, the distance between the earthquake epicentre and most distal rockfall increases with earthquake $\mathrm{M}_{\mathrm{w}}$. There is no detectable correlation between slope aspect, number of boulders produced, and the epicentral location of the $M_{w} 6.2$ Christchurch earthquake relative to the rockfall source areas, suggesting that earthquake source directivity did not exert strong influence over which slope aspects preferentially yielded rockfalls (Massey et al., 2014).

The lowest instrumentally recorded PGA for an earthquake in which severe, but localised, cliff collapse occurred was $\sim 0.7 \mathrm{~g}$ in the 16 April $M_{w} 5.3$ earthquake (Table $S 1$ ). Isolated rock spall from cliffs occurred at PGA $\sim 0.3 \mathrm{~g}$. Landsliding and loess cracking was locally observed at $P G A \geq 0.2 \mathrm{~g}$ and regionally observed at $P G A \geq 0.4 \mathrm{~g}$. In situ boulder fracturing was only observed following the $\mathrm{M}_{\mathrm{w}} 6.2$ Christchurch earthquake, implying that the intense high frequency ground accelerations in this earthquake were required to induce this effect.

In addition to PGA and PGV, peak ground displacement, shaking duration, and frequency content played an important role in causing boulder displacements on low relief summit surfaces. PGA in the $\mathrm{M}_{\mathrm{w}}$ 7.1 Darfield earthquake is estimated to be $~ 30 \%$ of the Christchurch earthquake PGA, however larger spectral accelerations were generated in the former at lower frequencies $(\leq 0.2 \mathrm{~Hz})$ and larger peak ground displacements (Bradley et al., 2014). Khajavi et al. (2012) concluded that increased shaking duration and intensity at longer periods in the $M_{w}$ 7.1 Darfield earthquake may have increased the momentum transferred to boulders, resulting in dynamic effects such as ramping of boulders against soil sockets and subsequent displacements. Thus, whilst in general the severity of mass movements increased with increasing ground shaking intensity, at any particular site other characteristics of a particular earthquake may have caused effects that were not duplicated by subsequent, and perhaps stronger intensity earthquakes.

Stahl et al. (2014) attributed the landslide fissure features in Fig. 18A to have been triggered by shaking with a minimum PGA $\sim 0.4-0.5 \mathrm{~g}$ and suggested that topographic and geometric amplification may have increased PGAs at the ridge crests where these features were observed. No subsequent displacements occurred in any of the CES aftershocks, although the largest of these events generated PGA $<0.1 \mathrm{~g}$; Stahl et al. (2014) conservatively assigned a triggering PGA of $\sim 0.1$ to $0.5 \mathrm{~g}$.

The river channel mass movement features shown in Fig. 18B are located between the extrapolated locations of the $M_{w}$ 7.1 Darfield earthquake 0.1 and $0.2 \mathrm{~g}$ PGA contours; given the uncertainty to which these features initially formed in this event and/or were triggered by more proximal aftershocks, we cautiously assign a triggering threshold of $0.1 \mathrm{~g}$ for these features.

\subsubsection{Palaeoseismic implications}

Mass movements have occurred frequently in the CES region over the historical time period; 17 landslides and rockfalls in Banks Peninsula occurred between 1870 and 1923 including four rainfall-triggered landslides that collectively caused five fatalities (Della Pasqua et al., 2014). More than 500 shallow landslides occurred primarily in loessic sediments during a high rainfall event in 1975 (Harvey, 1976). A major rockfall event occurred in Sumner (Fig. 15A) in 1907. Most recorded historical landslides in the Port Hills have comprised relatively shallow (less than $5 \mathrm{~m}$ deep) and small (less than $100 \mathrm{~m}^{3}$ in volume) earth/ debris flows in loess and loess-derived materials. Following the CES, a large debris flow of 1000-2000 $\mathrm{m}^{3}$ comprising remobilised loessic sediment occurred in Lyttelton (Fig. 15A) during a rainstorm on 5 March 2014. Of the historical mass movements documented, only two appear to have been coseismic; the collapse of several tons of loose rock from the south side of Lyttleton Harbour into the sea during the 1870 Lake Ellesmere earthquake (The Christchurch Star, Sunday Sept. 3 1870), and the fall of blocks of rocks 10 tons in weight from the high bluffs, Sumner-road, near Lyttelton, into Lyttelton harbour in the 1888 Hope Fault earthquake (Sydney Morning Herald, 3 Sep. 1888). The entrance to Monck's Cave (Fig. 15A) was sealed by a landslip sometime after ca. 1400-1500 A.D., the youngest age limit of cultural layers in the cave's interior (Jacomb, 2008), and prior to 1899 when the cave was discovered by workmen removing earth for road fill. Jacomb (2008) speculated that the cave entrance may have been sealed at ca. 1400-1500 A.D. because the exterior of the cave retains a short occupational chronology that extends another century beyond the interior chronology, although the timing and origin of the landslip remain unconstrained and its possible relationship to earthquakes untested. The spatial extent and severity of historical, rainfall-triggered shallow landsliding exceeds any shallow landsliding attributable to the CES. As a consequence, palaeo-landslides in loessic sediments are unlikely to provide suitable proxies for palaeo-earthquakes in this setting.

Pre-CES historical and prehistoric rockfall deposits have been mapped in the Port Hills by Townsend and Rosser (2012), DellaPasqua et al. (2014), Mackey and Quigley (2014), and Borella et al. (in review). To date, only the studies of Mackey and Quigley (2014) and Borella et al. (in review) provide chronologic information on the timing of prehistoric rockfall events at a site where rockfalls of equivalent dimensions, spatial distributions, and source cliffs occurred during the CES. The youngest pre-CES major rockfall event at this site occurred at ca. 6-8 ka with a possible preceding event at ca. 13-14 ka. Mackey and Quigley (2014) suggested on the basis of PGV modelling that local blind faults involved in the CES were the most likely palaeoearthquake(s) sources, although they could not dismiss the possibility of larger-than-expected earthquakes on mapped faults (Litchfield et al., 2014) and/or other unknown faults as possible rockfall sources. Buried rockfall deposits have been uncovered in some drillholes beneath Holocene coastal and dune deposits in southeast Christchurch (Canterbury Geotechnical Database; https://canterburygeotechnical database.projectorbit.com) but their relationship to palaeoearthquake activity is currently unknown and they have not yet been dated. Other prehistoric slope failure deposits have been identified (Della-Pasqua et al., 2014), however their chronology and possible relationship to seismicity is currently unknown. Loess cracking features formerly attributed to palaeoclimatic processes (Harris, 1983) may relate to seismic activity, although these have not been investigated in detail and their origin is unresolved.

No palaeoseismic investigations of displaced boulders on summit surfaces (Figs. 15H, 17) have been undertaken to date. However field observations of CES displaced boulders suggest that these features could theoretically provide information pertinent to past earthquakes by (i) exposing formerly buried rock surfaces that could be dated in the future by cosmogenic nuclides (e.g., Mackey and Quigley, 2014), lichenometry (e.g., Bull and Brandon, 1998) or other surface age determination techniques, (ii) burying soils and organics that could be extracted from beneath boulders and dated in the future to determine burial age, and/or (iii) abandoning soil sockets or creating gaps in soil sockets around boulders where future sediment will infiltrate, enabling the timing of socket abandonment or enlargement to be dated by infilled sediment (Fig. 17). Given the consistency between the azimuth of transient peak ground displacement and the dominant boulder displacement azimuth (Fig. 17D), the potential for palaeo-boulder displacements to reveal seismologic characteristics including directions of transient ground motions is an exciting, albeit challenging avenue for future research. The extent to which in situ boulder fragmentation could be dated and used reliably to infer past earthquakes remains untested at present.

The preservation potential of CES-generated mass movement deposits over time scales exceeding $10^{3} \mathrm{yr}$ is generally high, and pre- 

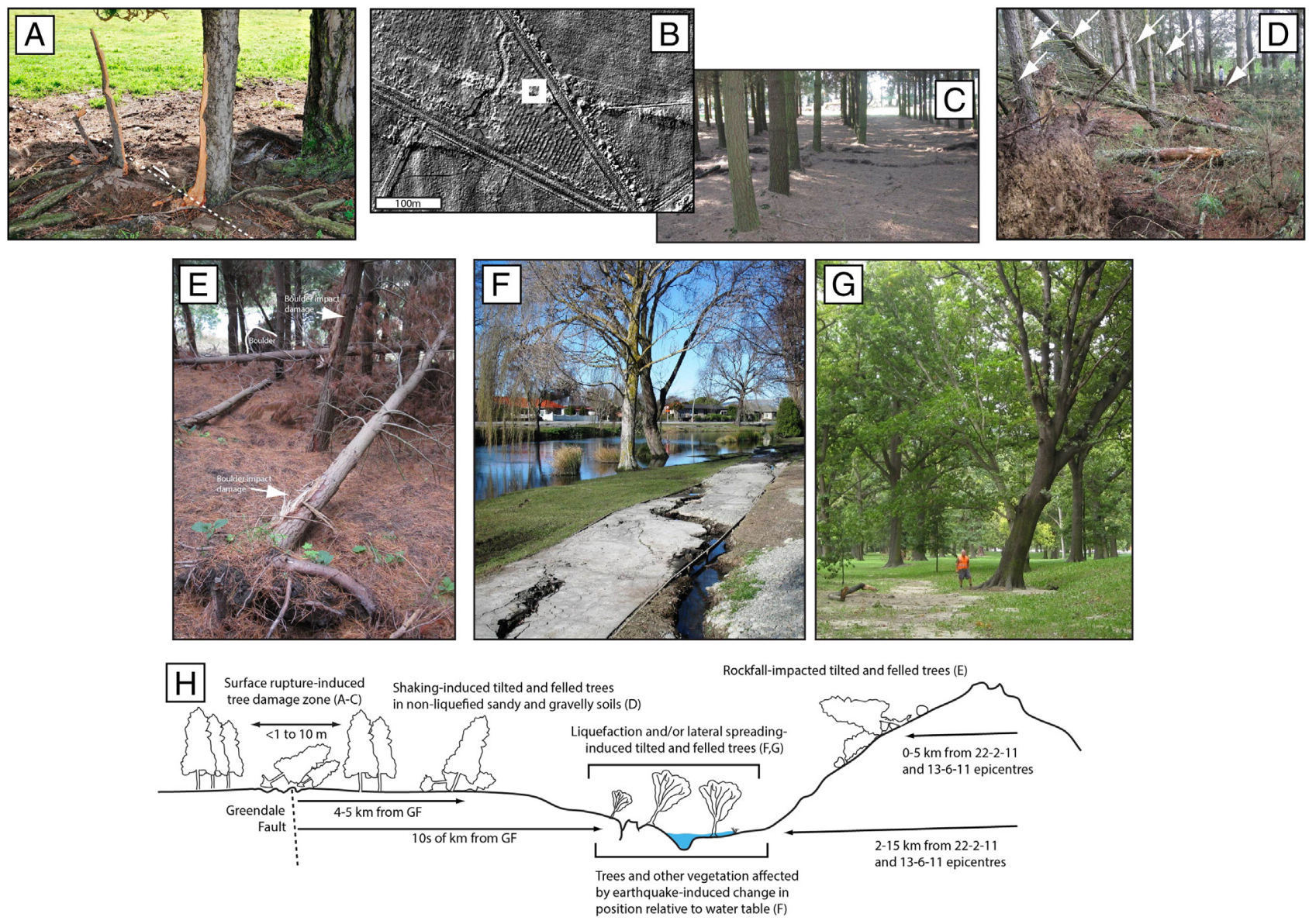

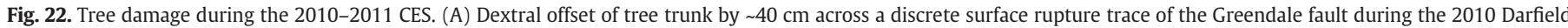

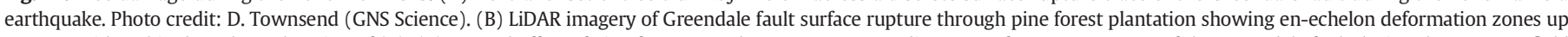

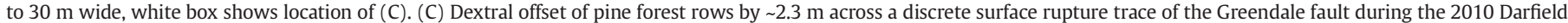

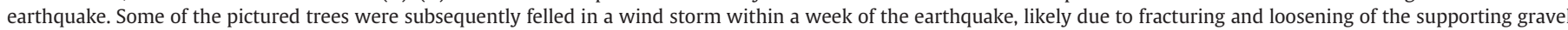

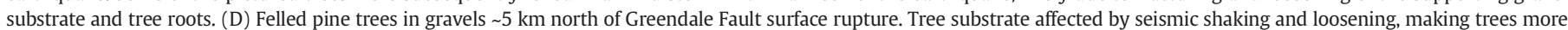

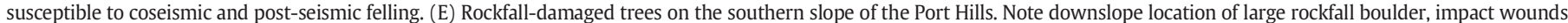

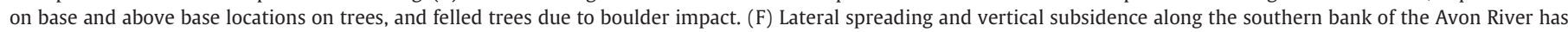

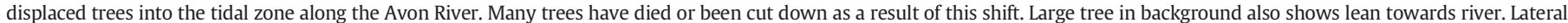

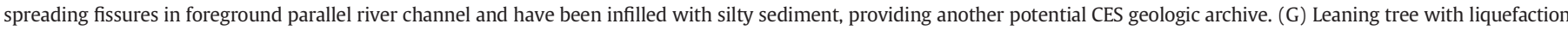

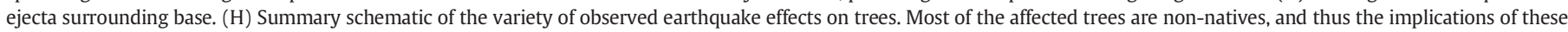

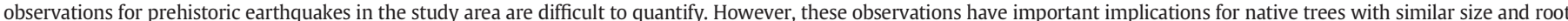
structure (e.g. beech trees) and for equivalent species in other parts of the world.

CES historic and prehistoric analogues have been identified in many instances. However, the reliability of using prehistoric mass movements to infer characteristics of past earthquakes depends on the type of mass movement considered. Shallow landslides are not reliable proxies given the abundant historical occurrence of these features in the absence of seismic triggering, the lack of a major increase in severity and extent of these failures during the CES, and the high dependence on nonseismic conditions such as subsurface hydrology. Although individual rockfall boulders may detach and be deposited by a variety of nonseismic processes, careful study of large numbers of rockfall boulders in areas where transport by other processes (e.g., fluvial activity) is less likely, and where direct evidence for CES rockfall exists, have provided promising first results (Mackey and Quigley, 2014; Borella et al., in review). Analysis of prehistoric geologic features such as loess fissures, displaced boulders, cave collapses, buried talus deposits, and in situ fractured rocks provide opportunities for future palaeoseismic research (Fig. 16).

Stahl et al. (2014) excavated a head scarp of the fissures shown in Fig. 18A and concluded that there was no evidence of prior slip over a time period that is likely to exceed the recurrence interval (10002500 years) of landslide-triggering PGAs experienced at this location in the $M_{w}$ 7.1 Darfield earthquake. They suggested that specific seismologic attributes of the $\mathrm{M}_{\mathrm{w}}$ 7.1 Darfield earthquake and/or inter-event changes (e.g. de-vegetation) may have influenced the location of landsliding in this instance, highlighting some of the complexities of studying PGA recurrence intervals through earthquake shaking proxies. No palaeoseismic investigations have been undertaken on river channel mass movement features analogous to those observed following the $M_{w}$ 7.1 Darfield earthquake (Fig. 18B).

\subsection{Groundwater hydrologic effects}

\subsubsection{Effects and distribution}

The $\mathrm{M}_{\mathrm{w}}$ 7.1 Darfield earthquake induced hydrological changes of greatly varying spatial and temporal characteristics recorded within the epicentral region and as far afield as the northern North Island (Fig. 19). Cox et al. (2012) review these effects, many of which reoccurred during CES aftershocks, but which were less welldocumented then because of damage to the hydrological monitoring infrastructure during the $\mathrm{M}_{\mathrm{w}}$ 7.1 Darfield earthquake.

The CES had pronounced and likely permanent effects on surface water and groundwater systems across the central South Island. Coseismic 

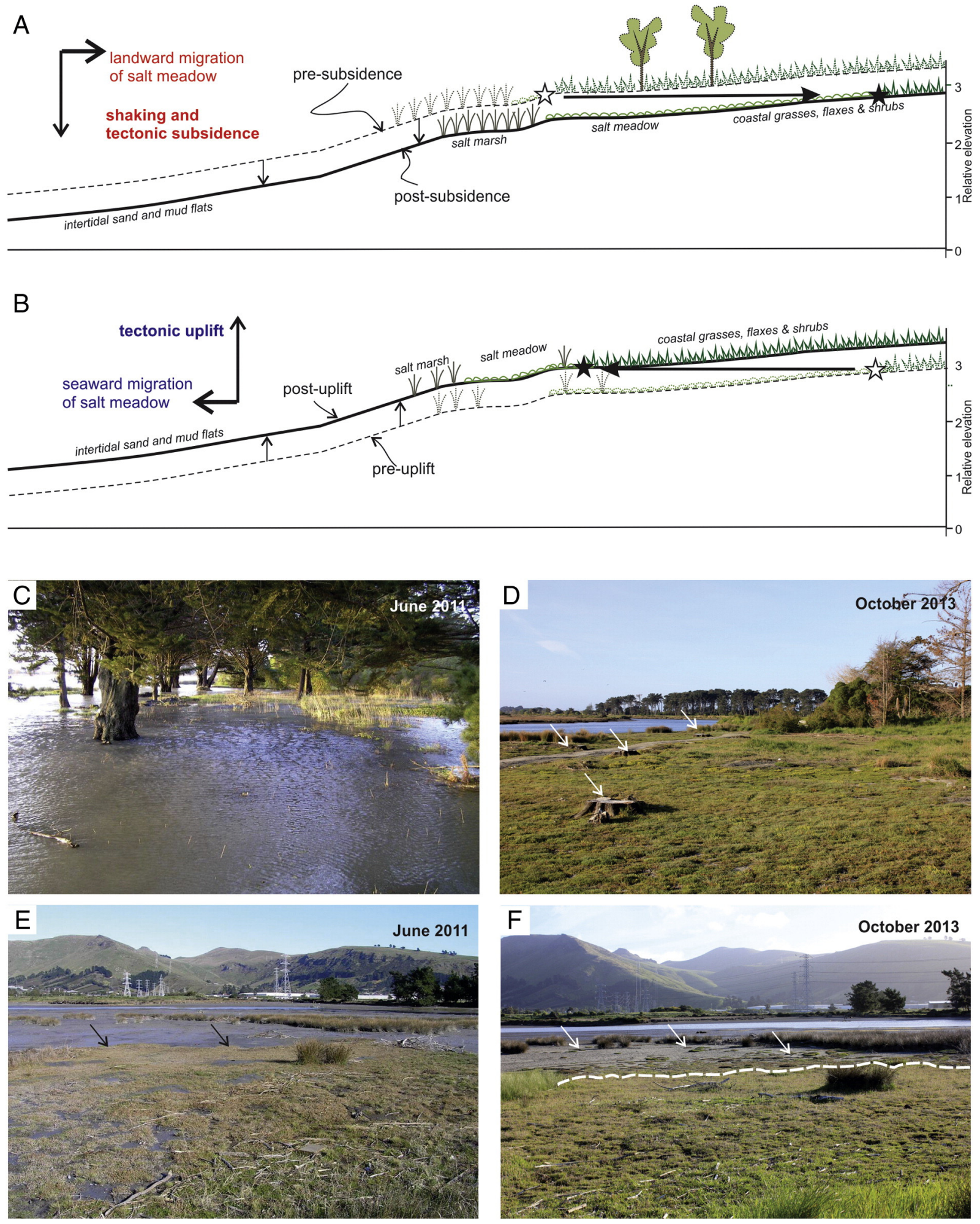

Fig. 23. Response of estuarine salt meadow to ground deformation. (A-B) Schematic representation of typical tidal zonation of salt meadow, salt marsh and inter-tidal flats in southern New Zealand, and migration of those zones in response to deformation. Stars indicate relative change of position of saltmarsh boundary with deformation, dashed line indicates schematic pre-deformation ground position, elevation changes are representative. (A) Migration of tidal plant zones in response to subsidence (see C-D for field images). (B) Migration of tidal plant zones in response to uplift (see E-F for field images). (C) Bridge Street reserve in the northern estuary in 2011, following subsidence, showing inundation of coastal plant zone at high spring tide; tide is covering grasses and plants that normally grow above high spring tide. (D) Same site in October 2013, taken at a lower tide after two growing seasons, showing migration of salt meadow plants landward to surround stumps of pre-deformation large trees (arrows). (E) Southern estuary site in June 2011 following uplift with salt meadow still representing a pre-deformation position, seaward edge of the salt meadow arrowed. (F) Same site in October 2013 after two growing seasons and the migration of salt meadow plants seaward (arrows) in response to uplift. Dashed line indicates margin of pre-deformation salt meadow. 
changes in pore water pressure caused near instantaneous $>20 \mathrm{~m}$ spikes in groundwater levels close to the Greendale Fault (Fig. 20A, B) (Cox et al., 2012), whilst hot-springs more than $140 \mathrm{~km}$ west of the $M_{w} 7.1$ Darfield epicentre cooled by $\sim 1{ }^{\circ} \mathrm{C}$ over several days starting $\sim 140$ min following the passage of seismic waves (Cox et al., 2015). In the aftermath of the $M_{w} 6.2$ Christchurch earthquake, extensive flooding of residential areas due to the combined effects of liquefaction, groundwater spring formation and compromised infrastructure, was perhaps the most widespread threat to human health and property.

The major hydrological responses to the CES include: 1) coseismic river avulsion and surface flooding; 2) prolonged post-seismic increases in deep near-field groundwater levels; 3 ) formation of tens to hundreds of new springs, and (4) macroscopic shifts in fluvial sediment transport dynamics associated with extensive liquefaction and lateral spreading in low-lying streams (Fig. 19). Widespread surface flooding in response to the Christchurch earthquake was perhaps the most salient hydrological effect of the CES. Recent estimates suggest that between 5000 and 10,000 residential properties are more prone to flood events (http://www.stuff.co.nz/the-press/news/christchurch-earthquake2011/7798091/New-flood-rules-for-properties-released) as a direct consequence of the topographical and hydrological effects of the CES.

Groundwater aquifers in the central Canterbury plains and Christchurch have also shown prolonged and possibly permanent responses to the CES. Deep unconfined to semi-confined aquifers close to the Greendale Fault showed the largest coseismic groundwater level responses to the $M_{w}$ 7.1 Darfield earthquake, including some wells that recorded $>20 \mathrm{~m}$ near-instantaneous rises in water level (Cox et al., 2012). More than four years after the $M_{w} 7.1$ Darfield earthquake, at least four of these wells remain 6 to $10 \mathrm{~m}$ above their pre-earthquake water levels with some of the highest post-earthquake water levels recorded in 2013 and 2014 (Fig. 20). These elevated groundwater levels cannot be a response to increased recharge as there is no significant difference between pre- and post-earthquake average precipitation or river discharge in the region (Fig. 20D, E). It is much more likely that the prolonged response of water levels in these wells is a direct result of elevated pore water pressures associated with increased bedrock permeability close to the fault, decreased aquifer permeability down gradient, or both. Interestingly, the pronounced seasonality of water levels in these four wells has largely remained the same suggesting the timing and magnitude of surface derived recharge and agricultural abstraction are similar both prior to and following the $\mathrm{M}_{\mathrm{w}} 7.1$ Darfield earthquake. In contrast, a fifth well (M35-1384; Fig. 20), located in the artesian Wainoni Gravels aquifer $122 \mathrm{~m}$ below Christchurch, has only risen $~ 1 \mathrm{~m}$ above its long-term pre-earthquake mean water level between 2013 and 2014 (Fig. 20B), almost certainly in response to the elevated post-earthquake hydrologic gradient between the elevated deep aquifers in the central Canterbury plains and the Christchurch artesian aquifer system.

Earthquake-induced rises in groundwater levels, hydrologic gradient, and bedrock permeability are consistent with the observed new appearance of 50-100 groundwater fed springs in the Christchurch area during the CES (van Ballegooy et al., 2014b). Stable oxygen isotope compositions suggest earthquake-induced springs and associated flood waters were sourced from near-surface meteoric-derived groundwater in the days immediately after the $\mathrm{M}_{\mathrm{w}} 6.2$ Christchurch earthquake (Fig. 21); by mid-March, 2011, earthquake spring isotopic compositions were indistinguishable from central Canterbury plains groundwaters. The groundwater level data and earthquake spring isotopic results are compatible with two distinct hydrogeological responses to the CES: 1) near-field coseismic spikes in pore water pressure associated with seismic energy release/shaking; and 2) enhanced bedrock permeability associated with rock and soil mass fracturing and dilatation induced by seismic shaking. In some instances, pore fluid pressure increases induced by preceding earthquakes are likely to have increased the liquefaction vulnerability and severity in subsequent earthquakes (Fig. 12).

Within $2 \mathrm{~km}$ of the Greendale Fault trace, the unconfined groundwater table rose by several tens of metres (Fig. 20B) (Cox et al., 2012), producing widespread uncontrolled artesian flows from bores and from earthquake-induced ground fissures. Fissures surrounded by localised deposits of sand and gravel ejecta attest to the force of the groundwater expulsion (P. Villamor, GNS Science, pers. comm, 2010).

\subsubsection{Seismologic thresholds}

Short- to medium-term coseismic spikes and/or step offset changes in piezometric levels ranging from millimetres to metres were recorded at many sites throughout New Zealand following the $M_{w}$ 7.1 Darfield earthquake. Transient, post-seismic decimetre-scale fluctuations eventuating in an $\sim 27 \mathrm{~cm}$ drop took place over $>25$ min following the $\mathrm{M}_{\mathrm{w}}$ 7.1 Darfield earthquake in a borehole in basalt at Puriri Park, Whangarei, $\sim 780 \mathrm{~km}$ north of the epicentre (Figs. 2A, 19). A $>4 \mathrm{~m}$ increase in piezometer height was recorded from a schist landslide near Clyde Dam $280 \mathrm{~km}$ southwest of the epicentre (Figs. 2A, 19). In both cases, the recovery time to pre-earthquake levels took $\sim 1 \mathrm{yr}$. Based on these and other similar responses to distal earthquakes, Cox et al. (2012) concluded that minor groundwater level changes are common at $400 \mathrm{~km}$ distances and may occur up to $1000 \mathrm{~km}$ from earthquake epicentres despite site specific PGAs «0.01 g. Some boreholes closer to the epicentre showed no response, however, highlighting the importance of local site geologic and hydrologic conditions on the occurrence and magnitude of a site response; rocks or sediments with low permeability are in general more sensitive to seismically-induced groundwater level changes than those in Quaternary gravel aquifers (Cox et al., 2012).

The minimum shaking intensity required to develop temporal excess pore water pressure in liquefaction-susceptible sediments with a low liquefaction triggering resistance is less than the seismic shaking intensity required to cause ground surface manifestation of liquefaction (i.e. PGA $_{7.5}$ of 0.11 to $0.13 \mathrm{~g}$ ). Whilst the development of temporal excess pore water pressure was measured for many of the smaller aftershocks following the earthquakes which caused ground surface manifestation of liquefaction (Fig. 12), it is likely that the elevated excess pore water pressures and temporal loss of soil strength from the main earthquakes will have significantly reduced the levels of the minimum shaking intensity required to develop temporal excess pore water pressure. Further research is being undertaken to examine the measured excess pore water pressure responses for various elapsed times following earthquakes which liquefied soils.

Ground water expulsion and subsequent flooding in the absence of liquefaction took place in the $\mathrm{M}_{\mathrm{w}}$ 7.1 Darfield earthquake near the junction between the Charing Cross and Greendale Faults, where local PGAs likely exceeded $1 \mathrm{~g}$ (e.g., GDLC $=1.25 \mathrm{~g}$ ). The occurrence of surface flooding depends upon the depth of the ground water table and severity of groundwater fluctuation, but this value provides a starting point for surface flooding induced by water table fluctuations in the absence of liquefaction. Surface flooding in Christchurch coeval with ground surface manifestation of liquefaction was induced in earthquakes with $\mathrm{PGA}_{7.5} \geq 0.18-0.2 \mathrm{~g}$.

\subsubsection{Palaeoseismic implications}

The spatial and temporal complexity of hydrological effects is compounded by the fact that they are driven largely by perturbations to subsurface conditions. In the geologic record, most earthquakeinduced hydrological effects (e.g. flooding, avulsion, spring formation) will be manifest as changes in surface sedimentation. Such changes will be almost impossible to differentiate from similar climate- or weather-induced changes in sediment structure, texture and composition. However, in certain contexts when multiple lines of evidence are available, such as well-sorted course silt to fine sand flood deposits that are coeval with evidence for ground surface manifestation of liquefaction (i.e. interlayered with sand volcanoes and/or fissures, or are traceable into feeder dikes), it may be possible to interpret both the hydrologic mechanism and seismic source of well-preserved strata. Groundwater fluctuations of up to several metres could be manifested as changes in sediment oxidation levels, pedogenic facies, or other 


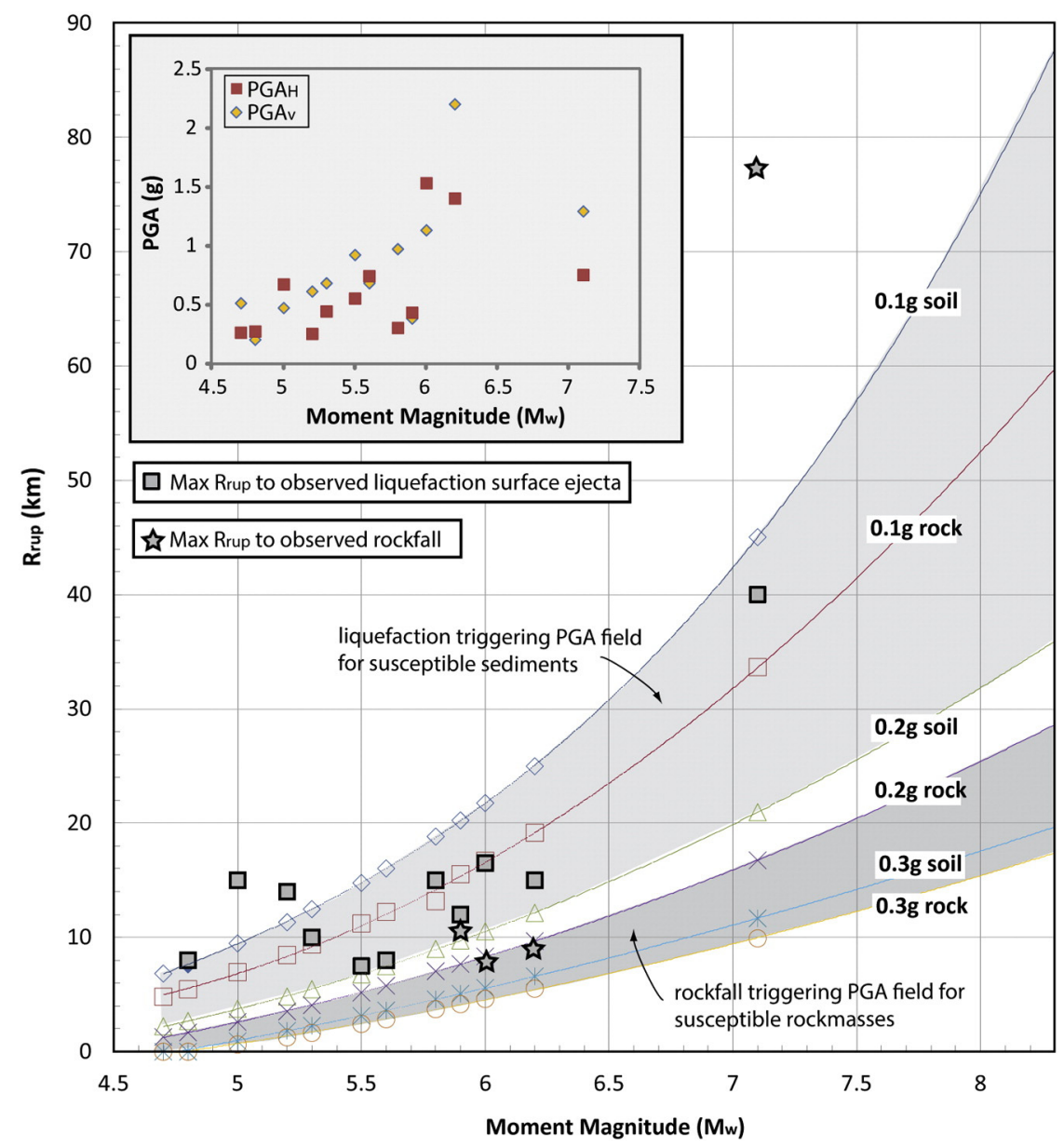

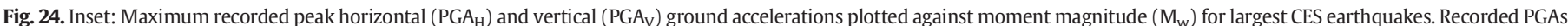

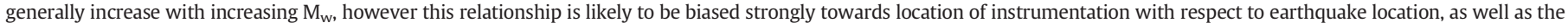

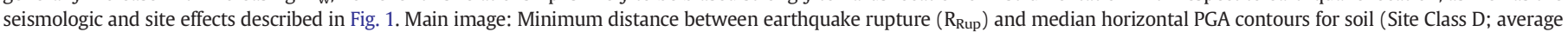

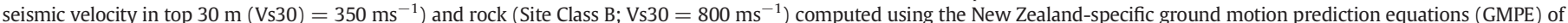

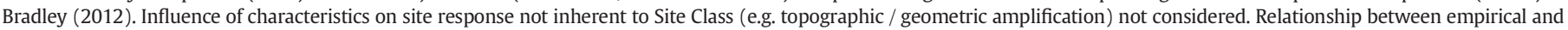

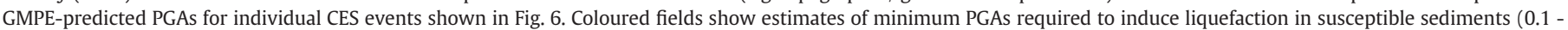

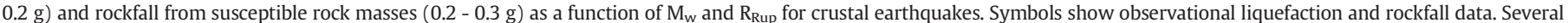

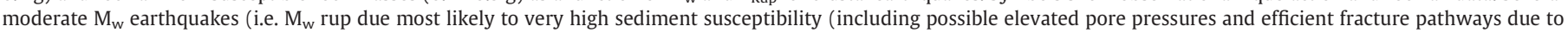

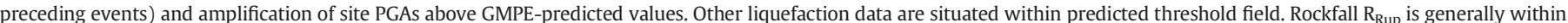

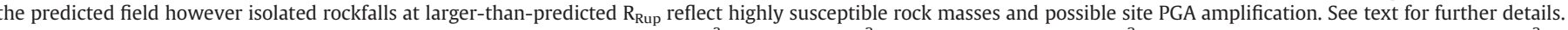

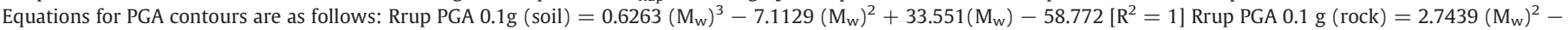

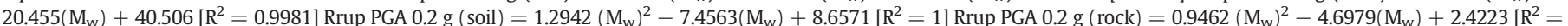
0.9999] Rrup PGA $0.3 \mathrm{~g}($ soil $)=0.474\left(\mathrm{M}_{\mathrm{w}}\right)^{2}-0.6423\left(\mathrm{M}_{\mathrm{w}}\right)-7.6553\left[\mathrm{R}^{2}=0.9993\right]$ Rrup PGA $0.3 \mathrm{~g}($ rock $)=0.5357\left(\mathrm{M}_{\mathrm{w}}\right)^{2}-2.0672\left(\mathrm{M}_{\mathrm{w}}\right)-2.3508\left[\mathrm{R}^{2}=0.9986\right]$.

such subsurface features, however the likelihood that these changes (if present) could be unambiguously attributed to earthquakes is low.

\subsection{Effects on trees and other flora and fauna}

\subsubsection{Effects and distribution}

5.7.1.1. Terrestrial flora. The Greendale Fault surface rupture propagated through two stands of commercial pine (Pinus radiata) forest for rupture lengths of $\sim 160 \mathrm{~m}$ and $\sim 80 \mathrm{~m}$, and through more than 15 different isolated rows of established pine and poplar trees (i.e. 'shelter belts'). Faulting-induced tree impacts are highly localised to the main rupture zone. Impacts included tree trunk rupture and displacement (Fig. 22A) and formation of 10-20 m-wide surface deformation zones (Fig. 22B) comprised of several discrete fractures that caused tree row offsets (Fig. 22C). Within these deformation zones, numerous trees were blown over during strong winds occurring within one month of the $\mathrm{M}_{\mathrm{w}}$ 7.1 Darfield earthquake. Subsequent severe gales during September and October 2013 caused widespread damage to trees. Root plate failure occurred, in many cases leading to trees tipping over. However, Canterbury experiences frequent gales without similar effects on its trees. The effect to which strong shaking destabilised root systems and thus rendered trees more susceptible to wind-induced damage has not been quantified. In the near field it seems likely that surface faulting during the $\mathrm{M}_{\mathrm{w}}$ 7.1 Darfield earthquake may have caused subsurface damage to tree root systems and their supporting sediment, which only became apparent when severe winds struck. This is consistent with reduced seismic velocity and distributed fault displacement across zones up to 100-150 m wide perpendicular to the principle slip zone on the surface rupture (Li et al., 2014; Van Dissen et al., 2013). Surface rupturing may thus have impacted tree roots and their anchoring function. Reconnaissance observations also indicate that trees immediately outside of the surface faulting zone, including those within the broad zone of surface folding, show little visual evidence of damage in areas where major shaking-induced soil disturbance was not noted. In some cases, trees show no externally obvious effects where up to 3 to $4 \mathrm{~m}$ of lateral surface displacement has occurred over $60-100 \mathrm{~m}$ wide zones. 


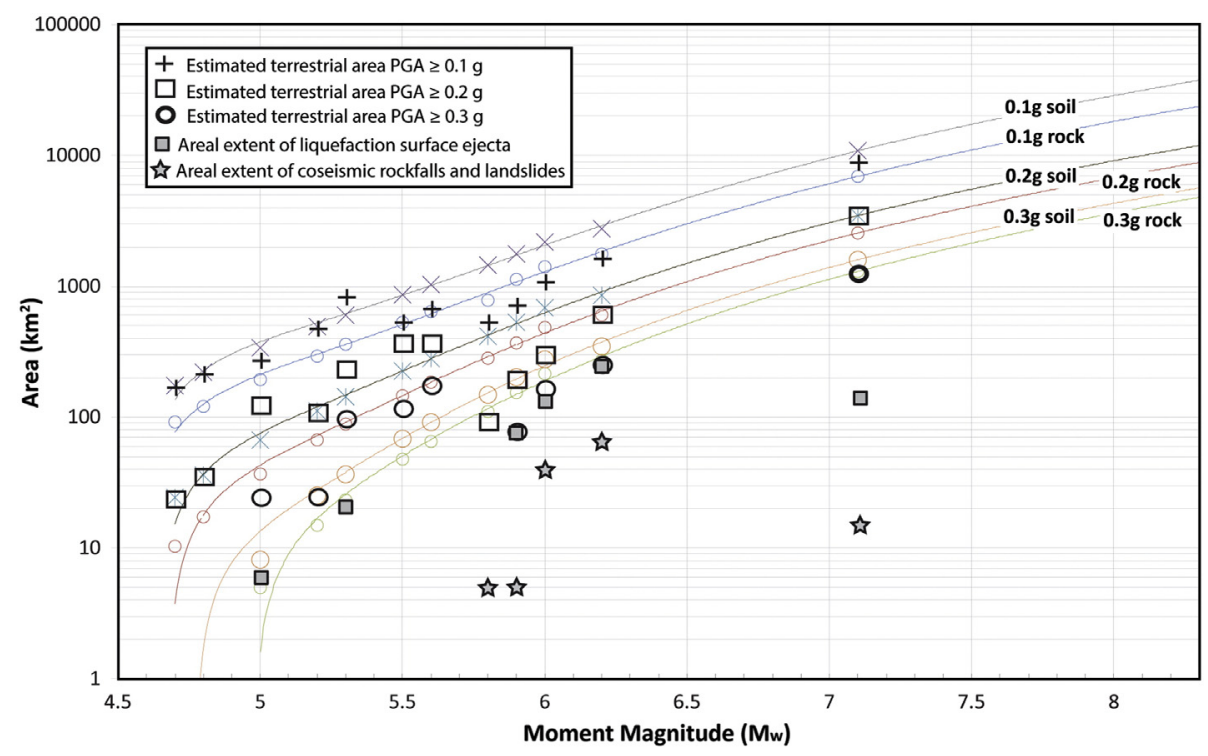

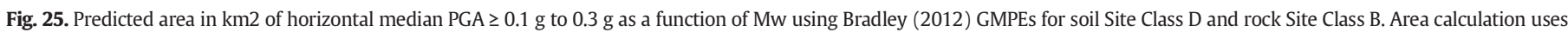

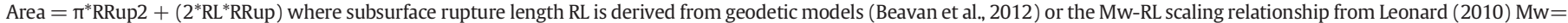

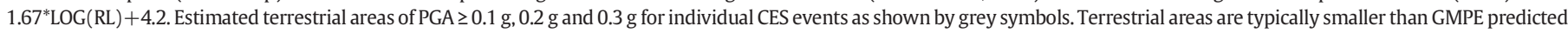

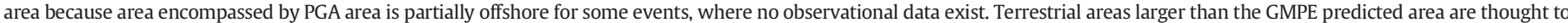

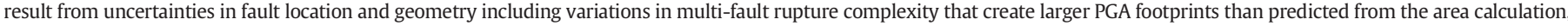

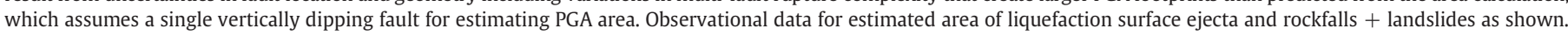

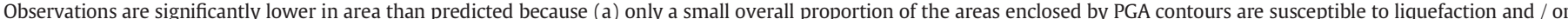

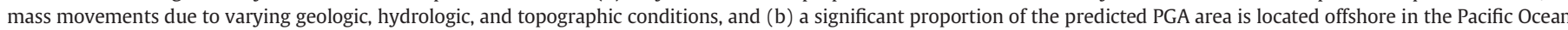

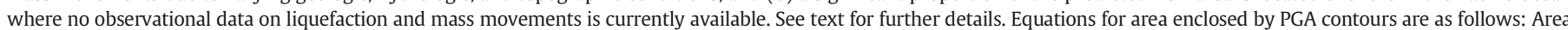

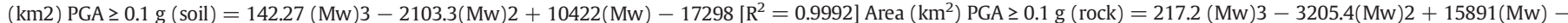

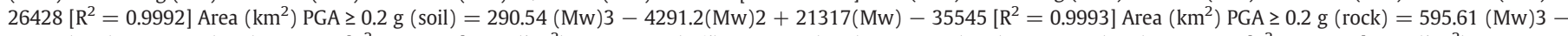

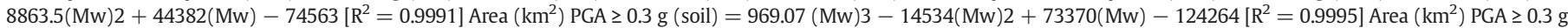
$($ rock $)=132.72(\mathrm{Mw}) 3-2010.9(\mathrm{Mw}) 2+10229(\mathrm{Mw})-17463\left[\mathrm{R}^{2}=0.9992\right]$.

Shaking-induced tree disturbance throughout the CES was not comprehensively documented and no efforts have been made to date to map the extent and severity of tree disturbance across the affected landscape. Some trees residing on gravel substrates affected by strong shaking were toppled either co-seismically or post-seismically (in subsequent strong winds) (Fig. 22D). Tree disturbance on public land was relatively well-described following the 2011 Christchurch earthquake, due to the Christchurch City Council's (CCC) removal of trees assessed to pose a public safety risk. All $\sim 65,000$ park trees managed by the CCC were visually assessed following the Christchurch earthquake and, of these, 384 were deemed to pose such risk as to be removed. Anecdotal evidence suggested that rows of mature oak trees (140 years old) shook violently from side to side in unison, resulting in severe lean and root plate failure (Walsh and Moohan, 2011). Nearly 65\% of tree removals resulted from trees expressing severe lean (Fig. 22G), with extreme cases where tree stems had snapped or root plates had failed (Morgenroth and Armstrong, 2012).

Another process influencing tree health resulted from the impacts of large falling rocks that impacted trees with sufficient energy to snap the trunk or damage the tree bark and cambium, leaving impact wounds (Fig. 22E). Wounds have been found many metres high in trees, indicating falling rocks did not merely roll on the surface, but also bounced downhill (Morgenroth and Armstrong, 2012).

The major effects of subsidence and uplift on trees are related to the relationship between root growth and the water table. Subsidence of up to $1 \mathrm{~m}$ in the eastern suburbs (Fig. 8), commonly associated with areas of severe liquefaction and lateral spreading (Fig. 22F), resulted in a relative upwards shift of the water table towards the land surface and a more anaerobic rhizosphere. In some cases, trees that were formerly on river banks experienced lowering to the extent that they moved into river channels covered by the daily tidal zone. Many tree species are sensitive to overly wet soils, which limit the oxygen available for root respiration (Vincke and Delvaux, 2005). The hydrological shift caused by subsidence was likely responsible for the widespread decline (and eventual death) of a 19 ha pine and macrocarpa forest at the Bridge Street reserve (Figs. 8D, 23) in the weeks following the $M_{w} 6.2$ Christchurch earthquake (Morgenroth and Armstrong, 2012). At this location, the ground surface and groundwater dynamics following each major earthquake events is presented in Table S3 (electronic supplement). Following the $\mathrm{M}_{\mathrm{w}} 6.2$ Christchurch earthquake, the ground surface dropped by $34 \mathrm{~cm}$ whilst the ground water surface rose by $11 \mathrm{~cm}$, resulting in the water table experiencing a net upward shift of $45 \mathrm{~cm}$. The consequence is that whilst prior to this event, roots could colonise $3.03 \mathrm{~m}$ of unsaturated soil, following the event, roots could only colonise $2.58 \mathrm{~m}$ of unsaturated soil. The widespread tree mortality for this location is evidence that a hydrological change associated with shakinginduced earthquake outcomes can leave a lasting biological signature on the landscape. Since these earthquake events, the CCC has replanted tree species tolerant of wet soils; it is likely that this artificial successional process would have occurred naturally, albeit more slowly, in the absence of human intervention.

Where liquefaction ejected sediment upwards onto the soil surface, it covered root systems of trees with up to $40 \mathrm{~cm}$ of finetextured sands (Morgenroth et al., 2014). Although the long-term effects of this sediment on tree health is unknown, a physical and chemical characterisation of the liquefaction ejecta (Morgenroth et al., 2014) indicates that trees will need to adapt to a new rooting environment. Previous work has shown that root systems generally occupy the surficial layers of soil to take advantage of sufficient soil oxygen, precipitation infiltration and relatively high fertility (Schnelle et al., 1989). New roots and the extension of existing roots buried beneath up to $40 \mathrm{~cm}$ of ejecta are most likely to grow upward in response to oxygen, moisture, and nutrient gradients (Copini et al., 2015). The result will be a distinct and lasting morphological divergence from other trees, whereby the root system would have a multi-tiered morphology. 
5.7.1.2. Estuarine flora and fauna. Shaking and tectonic vertical deformation combined to produce subsidence in the northern Avon-Heathcote Estuary (shaking-induced subsidence + tectonic subsidence), and uplift in the southern Estuary (tectonic uplift > shaking-induced subsidence). Estuary flora and fauna are sensitive to salinity and tidal elevation and are distributed in distinct zones, and CES vertical deformation forced existing flora and fauna into non-preferred tidal elevations. In areas of subsidence (Fig. 23) die-off of negatively affected inter-tidal plants began almost immediately due to excessive wetting, along with dieoff of adjacent terrestrial trees and grasses (Cochran et al., 2014). This was most apparent adjacent to the Bridge St Reserve. In areas of uplift plant die-off was not immediate as rain events were sufficient to sustain non tidal-wetted saltmarsh plants in the short term, and plants died progressively over the next three years (Cochran et al., 2014).

Elevation-sensitive inter-tidal plants migrated landward in response to subsidence and seaward in response to uplift (Fig. 23), and seedlings of pioneer saltmarsh plants first appeared in the following spring (November 2011) with new saltmarsh communities well established within two years of deformation (Cochran et al., 2014). Non-pioneer plant distributions are not yet stabilised. Large trees in the Bridge Street reserve (Fig. 23) were removed in May 2012 and inter-tidal saltmarsh plants dominated by glasswort established rapidly and stabilised soils loosened by tree removal. Disturbance to flora and fauna as a direct result of tectonic deformation is dominated by movement into new tidal zones, however disturbance to overall ecosystem function appears to be most influenced by urban sewerage draining into the AHE causing algal blooms and disturbing food webs (Zeldis et al., 2011).

Micro and macrofauna will also respond to altered tidal zonations, and larger organisms such as mobile gastropods and crustaceans have rapidly adjusted. Sediment-dwelling microfaunal elements, such as foraminifera, will respond in the same way, however mixing of old and new tests and recolonisation rates of foraminifera are not resulting in a clear shift when sampled three years post subsidence (Cochran et al., 2014), with only upper salt-marsh foraminifera showing evidence of a landward shift in subsidence sites (Hayward et al., 2015).

Inter-tidal rushes and sedges trap fine sediment about their roots and stalks, and die-off of these plants as a result of subsidence has resulted in exposure of the root mass and subsequent erosion of fine sediment further deepening the tidal elevation. Sedges and rushes act to attenuate waves and control shoreline erosion in estuaries (e.g., Möller et al., 1999). Subsidence, with or without subsequent dieoff has resulted in less efficient attenuation and waves eroding shorelines in locations previously protected by rushes in the northern AHE. Re-establishment of sedge and rushes in time will mitigate this, but in the interim local erosion is occurring.

The landward shift of inter-tidal flora and fauna is in places inhibited by built structures such as rock walls, and in the case of subsidence and localised flooding to residential areas, the development of flood stopbanks. Concrete and rock structures do not support estuarine intertidal flora and fauna, and zones are squeezed where they meet built structures. Plants, however, act to stabilise sediment surfaces and protect them from erosion, and the inability of plants to establish on coarse gravel stop-banks has resulted in even small waves removing matrix fines from stop-banks, causing gravel erosion and requiring ongoing maintenance. This is particularly prevalent in the northern estuary at the Avon River mouth.

\subsubsection{Seismologic thresholds}

The $\mathrm{M}_{\mathrm{w}}$ threshold for damage to trees due to discrete surface rupture is equivalent to the threshold required for surface rupture (6.6 \pm 0.1$)$. The $\mathrm{M}_{\mathrm{w}}$ threshold of $6.3 \pm 0.2$ for surface folding provides an estimate of the minimum $\mathrm{M}_{\mathrm{w}}$ required in order to induce responses of trees and other flora to tectonic deformation. The shaking threshold required to initiate responses in trees and other flora is highly dependent on the nature of the phenomena and setting. In highly susceptible sediments, earthquakes with PGA of 0.1-0.2 g caused liquefaction and lateral spreading, and thus may have influenced tree and other floral health via the mechanisms described above. The rockfall triggering threshold of PGA $0.3-0.4 \mathrm{~g}$ is adapted as a general shaking intensity above which significant rockfall impact induced tree damage is expected, with the recognition that individual rocks with the potential to impact trees may be displaced in lower shaking intensities or in the absence of earthquakes.

\subsubsection{Palaeoseismic implications}

Previous research has identified that long-lived trees and wellpreserved woody biomass can provide evidence of the timing of historic earthquakes. Tree-ring growth anomalies (Jacoby et al., 1997; Yetton et al., 1998; Wells and Yetton, 2004), fallen trees (Adams, 1980), buried organic material (Berryman et al., 2012), and identification of evenaged cohorts amongst uneven-aged forests (Yetton et al., 1998; Wells et al., 1999) have all previously been used to estimate the timing of palaeo-earthquakes.

The response of trees and other flora to the CES, including cohort die-off and floral and faunal species migration, occurred in areas where changes in surface elevation due to crustal deformation and surface subsidence relating to strong earthquake shaking were as small as $20-40 \mathrm{~cm}$ (Fig. 8). If trees are re-established in areas where die-off was significant, the newly established forest is a good example of how even-aged cohorts within an uneven-aged forest can be indicative of a major disturbance (Yetton et al., 1998; Wells et al., 1999). Where tree stems were snapped, stumps and roots were commonly left in the soil; this die-off event could perhaps be dated in the future using ${ }^{14} \mathrm{C}$ of woody detritus. Large woody roots buried beneath a homogeneous layer of liquefaction ejecta may also provide an important earthquake archive. Localised wounding of a large number of trees may prove to be a useful archive of the CES could be used to study palaeoearthquakes elsewhere. Trees will compartmentalise wounds to prevent decay from affecting the living tissue of trees (Shigo, 1984). In this way, a record of the date of wounding is preserved in the crosssection of all trees.

The seaward or landward migration of flora and fauna in response to uplift or subsidence respectively (Fig. 23), is the key effect expected to be preserved in the sediment record and has been used elsewhere as a means to determine fault rupture frequencies and magnitudes (Atwater, 1987; Hayward et al., 2006; Clark et al., 2011; Wilson et al., 2007). The high inter-tidal zone is most applicable as a proxy, yet only a limited area adjacent to the Avon and Heathcote river mouths would provide suitable coring sites in the CES example. As shaking-induced subsidence accentuates tectonic subsidence and counteracts tectonic uplift (Figs. 8, 11) an understanding of fault location and rupture style are key to selecting coring sites (Cochran et al., 2014). Blind faults by their nature are poorly known and are thus difficult to target. A record of subsidence is much more likely to be recorded in the AHE (Hayward et al., 2015; Vettoretti, 2014). Hayward et al. (2015) suggested that 1-2 Holocene settlement events, due most likely to earthquakes, occurred in highly susceptible sediments in parts of eastern Christchurch.

\section{Discussion}

6.1. Summary of earthquake environmental effects and relationships to site conditions, seismologic triggering thresholds, and preceding earthquakes

At least 12 earthquakes over $~ 16$ months, ranging in $\mathrm{M}_{\mathrm{w}}$ from 4.7 to 7.1, caused seismic shaking of sufficient intensity to induce environmental responses during the 2010-2011 CES (Tables 1-2A, 2B, S1-S3; Figs. 24, 25). Maximum instrumentally-recorded horizontal and vertical PGAs generally increased with increasing $\mathrm{M}_{\mathrm{w}}$ but were also dependent on the location of seismometers with respect to fault location (Fig. 1) and propensity for seismometer site amplification in a given earthquake. The distance from earthquake epicentre and most proximal 
rupture $\left(\mathrm{R}_{\text {rup }}\right)$ to most distal recorded environmental effect (e.g. liquefaction feature, mass movement feature, tree damage) generally increased with increasing $\mathrm{M}_{\mathrm{w}}$ (Table S1; Fig. 24). However, when plotted against median horizontal PGA contours for soil (Site Class D; average seismic velocity in top $\left.30 \mathrm{~m}(\mathrm{Vs} 30)=350 \mathrm{~ms}^{-1}\right)$ and rock (Site Class B; Vs30 $=800 \mathrm{~ms}^{-1}$ ) computed using the NZ-specific GMPEs of Bradley (2015), the data illustrate the challenges in applying $\mathrm{M}_{\mathrm{W}}-\mathrm{R}_{\mathrm{rup}}$ max to predict earthquake phenomena. For example, highly fragile rock masses may fail at greater-than-expected distances with PGA significantly lower than proposed triggering thresholds, and stronger more proximal rock masses may not fail even at extremely high PGAs. Challenges in estimating PGAs for variable site conditions, where geology or topography may amplify PGAs, highlight uncertainties in the seismic 'demand', whereas varying susceptibilities of different phenomena highlight variations in 'capacity'. Uncertainties in demand versus capacity are clearly evident in the occurrence of surface manifestations of liquefaction at larger-than-predicted distances and lower-than-predicted PGAs in moderate $\mathrm{M}_{\mathrm{w}}$ earthquakes (Fig. 24); such occurrences provide impetus for targeted future research.

Estimated terrestrial land areas affected by strong shaking (shown by symbols in Fig. 25) range from $<200 \mathrm{~km}^{2}$ to $>9000 \mathrm{~km}^{2}$ and generally increase with increasing earthquake $\mathrm{M}_{\mathrm{w}}$, as predicted from Area of horizontal median PGA $\geq 0.1$ to 0.3 g versus $M_{w}$ using Bradley (2012a, 2012b) GMPEs for soil Site Class D and rock Site Class B. Differences between empirically-estimated versus modelled PGA area versus $M_{w}$ curves relate to earthquake size and location; smaller $\mathrm{M}_{\mathrm{w}}$ earthquakes with epicentres furthest inland have the closest fits between empirical and predicted PGA areas because the largest percentage of total estimated strong ground shaking area occurred within the terrestrial realm. Offshore earthquakes and larger $\mathrm{M}_{\mathrm{w}}$ terrestrial earthquakes have significant components of predicted PGA areas offshore and thus show larger discrepancy between empirically estimated PGA land areas and modelled total areas (Fig. 25). Variations in lithospheric composition and structure (e.g., crustal seismic velocity), tectonic setting, site characteristics, and earthquake characteristics will influence seismic attenuation properties and site-specific PGAs (Fig. 1), thus influencing the applicability of the GMPE curves we present in Figs. 24 and 25 to other sites globally.

The GMPE and PGA Areas versus $\mathrm{M}_{\mathrm{w}}$ curves for both Site Class B bedrock and Site Class D sediment assume flat topography and uniform site characteristics; variations in topography and sediment type contribute further uncertainty to these estimates. The geography of the study region with respect to earthquake location is also highly relevant to understanding the empirical PGA area versus $\mathrm{M}_{\mathrm{w}}$ data we present; the occurrence of the CES over an area spanning terrestrial and marine realms influences the manifestation of this earthquake in the geologic record. The palaeogeography, including distribution of marine and terrestrial water bodies with respect to earthquake locations and PGA distributions, is important to consider when conducting palaeoseismic investigations using earthquake-shaking proxies.

In specific areas or at individual sites, the severity of an observed effect scaled with shaking intensity, typically PGA or PGV, rather than $\mathrm{M}_{\mathrm{w}}$ (Quigley et al., 2013; Mackey and Quigley, 2014; Massey et al., 2014). This is shown by increases in the areal extent and severity of ground surface manifestation of liquefaction (Fig. 10) and rockfall (Fig. 15A), increases in the number of recorded rockfall boulders (Massey et al., 2014), and increased amount of maximum cliff recession (Fig. 15D, E) with increased shaking intensities in the susceptible areas (Table S2). The amount of tectonic surface deformation scaled with $\mathrm{M}_{\mathrm{w}}$, and only source-specific earthquakes above $\mathrm{M}_{\mathrm{w}} 6.6 \pm 0.1$ caused discrete surface rupture. Field evidence for tectonic surface deformation occurred in blind fault earthquakes as small as $M_{w} 6.2$ and increased with increasing $\mathrm{M}_{\mathrm{w}}$.

Seismic shaking thresholds for environmental effects (Tables 2A and $2 \mathrm{~B}$ ) varied widely due to variations in the type of phenomena considered and the characteristics of the site. Hydrologic responses were invoked at particularly susceptible sites with PGAs « 0.01 g. Groundwater expulsion and subsequent flooding in the absence of ground surface manifestation of liquefaction took place where PGAs likely exceeded $\sim 0.5$ to $1.0 \mathrm{~g}$, whereas groundwater expulsion accompanying liquefaction was induced in earthquakes with PGA $\geq 0.15-0.2 \mathrm{~g}$ (Fig. 24C). Rockfalls occurred above horizontal PGAs of $0.3 \pm 0.1 \mathrm{~g}$ and severe rockfalls occurred above $\sim 1.0 \mathrm{~g}$. Cliff collapse occurred at susceptible sites at PGAs $\geq 0.7 \mathrm{~g}$ (Fig. 24C). Landsliding and loess cracking was locally observed at $\mathrm{PGA} \geq 0.2 \mathrm{~g}$ and regionally observed at $\mathrm{PGA} \geq 0.4 \mathrm{~g}$. Minor localised surface expressions of liquefaction in susceptible sediments with a low resistance to liquefaction triggering occurred at PGA $\geq 0.15 \pm$ $0.02 \mathrm{~g}\left(\mathrm{PGA}_{7.5} 0.11 \pm 0.02 \mathrm{~g}\right)$, and severe ground surface manifestation of liquefaction occurred at $\mathrm{PGA} \geq 0.2 \pm 0.01 \mathrm{~g}\left(\mathrm{PGA}_{7.5} \geq 0.18 \pm 0.01 \mathrm{~g}\right)$. Susceptible sediments with a higher resistance to liquefaction triggering required higher PGAs to liquefy and did not liquefy as frequently as the susceptible sediments with a lower resistance to liquefaction triggering. Lateral spreading and liquefaction-induced subsidence in susceptible sediments with a lower resistance to liquefaction triggering occurred at $P G A \geq 0.2 \pm 0.01 \mathrm{~g}\left(\mathrm{PGA}_{7.5} \geq 0.18 \pm 0.01 \mathrm{~g}\right)$. Environmental effects experienced in the largest CES earthquakes are assigned a corresponding Environmental Seismic Intensity scale metric (ESI 2007; Michetti et al., 2007) in Table 2; effects range from VIII (HEAVILY DAMAGING) to $\mathrm{X}$ (VERY DESTRUCTIVE).

Preceding earthquakes are likely to have increased the susceptibility of many sites to environmental responses in several instances. Increased pore fluid pressures induced by preceding earthquakes, decreased water table depths resulting from subsidence in preceding earthquakes, and fissuring and cracking of soil caps that provided more efficient ejecta escape pathways, are likely to have increased the severity of liquefaction in subsequent earthquakes. Rock mass fracturing and shaking-induced dilatation in preceding earthquakes is likely to have increased the susceptibility of source cliffs to future rockfalls. Earthquakeinduced subsidence and stream channel and gradient changes have increased the susceptibility of eastern Christchurch to future flooding (including coseismic flooding). From these perspectives, the seismic triggering thresholds we present in Tables $2 \mathrm{~A}$ and $2 \mathrm{~B}$ and in the coloured fields in Fig. 24 should be treated as approximate, with full acknowledgement that gradual or punctuated changes in the intrinsic properties of host media may influence both the characteristics of future site-specific seismic shaking and the susceptibility of a specific medium to future environmental effects.

\subsection{Geologic legacy of the CES and palaeoseismic implications}

The geologic legacy of the CES is governed by (i) the spatial distribution and severity of environmental effects and their initial manifestation in geologic, geomorphic, or biologic realms, and (ii) the preservation of these effects in the geologic, geomorphic, or biologic records. Some effects such as hydrologic changes are transient and unlikely to provide clear geologic evidence as to their occurrence (Tables 2A and 2B). Other effects such as coastal elevation changes are sufficiently subtle that they are unlikely to be interpretable from the geologic record. Surface features including liquefaction-induced sand blows, estuary sedimentation, and earthquake surface rupture fissures are highly susceptible to both natural and anthropogenic modification. Some effects such as river avulsion, isolated rockfalls, tree cohort damage, rock fragmentation, and shallow landslides can be triggered by climatic or meteorologic phenomena or can occur in the absence of a specific triggering mechanism and thus do not provide evidence uniquely diagnostic of earthquakes irrespective of their preservation in the geologic record. Some effects such as summit boulder displacements may be challenging to recognise in the geologic record. It may be highly challenging to distinguish between single versus multiple episodes of genesis in features such reactivated liquefaction feeder dikes and composite rockfalls. The close temporal recurrence and similar severity and distribution of environmental effects incurred in the 
$M_{w} 6.2$ Christchurch and 6.0 June earthquakes, for example, has resulted in distinct environmental effects that may not be easily distinguishable through geologic investigations.

Despite these limitations and uncertainties, a variety of earthquakeinduced effects generated features that will persist in the geologic record for $>10^{3}-10^{4}$ yrs if not disturbed by anthropogenic activities. Mass movements, including talus debris resulting from cliff collapse and rockfall deposits including large boulders, will provide a geologic legacy of the CES. Liquefaction-induced subsurface features including dikes and sills will persist at shallow depths $(<1-2 \mathrm{~m})$ below the surface. Evidence for fault rupture will persist in the shallow subsurface. If well dated, these features would overlap chronologically and indicate a major earthquake sequence. In support of this assertion, pre-CES liquefaction has been documented in highly susceptible late Holocene sediments, and preliminary evidence indicates recurrence intervals of $10^{2} \mathrm{~s}$ of yrs. Pre-CES severe rockfall has been estimated to have recurrence intervals of $10^{3} \mathrm{~s}$ of yrs. Surface-rupturing earthquakes on the Greendale Fault are estimated to have recurrence of $10^{4} \mathrm{~s}$ of years. Effects with higher seismic triggering thresholds and/or sites with lower susceptibility are expected to have longer recurrence intervals compared to effects with lower thresholds and/or sites with increased susceptibility. For example, no evidence for pre-CES liquefaction has been found in Late Holocene sediments in southern Christchurch that liquefied only under the high PGAs of the $\mathrm{M}_{\mathrm{w}} 6.2$ and 6.0 earthquake, suggesting that these deposits, in concert with investigations of more susceptible sediments, enable filtering of PGA recurrence intervals for various levels of PGA over geologic timescales.

Finally, given that the CES was highly clustered in time and space, it is worth commenting on the extent to which this clustered behaviour would be evident from the environmental effects we observe. We consider careful study of liquefaction feeder dike stratigraphy in areas particularly prone to lateral spreading (Fig. 9B) to provide one of the potentially most illuminating archives of earthquake clustering. Although areas less prone to lateral spreading may be more likely to incur complete dike reactivation during successive events (Quigley et al., 2013), areas with large coseismic extensional strains may enable the injection of sediment in distinct liquefaction events to be accommodated by successive dike infiltration on the edges of prior dikes (Fig. 9B). The close temporal proximity of these events would be revealed by indistinguishable dike weathering and disturbance patterns (e.g. oxidation, bioturbation) and stratigraphic relationships with host strata. Buried sand blows provide further, albeit likely incomplete, archives that may be interpretable in the context of earthquake clustering (Bastin et al., 2015). Other features such as talus deposits and rockfall boulders may provide good evidence for past earthquakes, but distinguishing single from multiple triggering events (as would be the case for a clustered earthquake sequence) exceeds the capability of geochronologic approaches to understanding the timing of these events.

\subsection{Is the CES over?}

The question of whether the CES is effectively 'over' can be addressed by (i) comparing current (i.e., 2015) seismicity rates to immediate post-mainshock (i.e., 2010-2012) rates and pre-CES (i.e., 19402010) rates for the CES region, (ii) considering whether faults that did not rupture completely in the CES but that are capable of future damaging earthquakes exist in the CES region, and (iii) comparing the CES with other analogous earthquake sequences globally. CES aftershock rates have declined post-mainshock (with rejuvenation following large aftershocks) in general accordance with modified Omori's Law. Annual rates of $\mathrm{M}_{\mathrm{L}} \geq 4$ and $\mathrm{M}_{\mathrm{L}} \geq 3$ earthquakes in 2015 are $8-14 \%$ of the 2012 rates and $\leq 2 \%$ of $\mathrm{M}_{\mathrm{L}} \geq 4$ and $\mathrm{M}_{\mathrm{L}} \geq 3$ average annual rates from September 2010 to September 2012 (Fig. 5). However, the annual rate of $\mathrm{M}_{\mathrm{L}} \geq 4$ and $\mathrm{M}_{\mathrm{L}} \geq 3$ earthquakes in the CES region in 2015 was 810 times as great as the average annual pre-Darfield earthquake rate of $\mathrm{M}_{\mathrm{L}} \geq 4$ and $\mathrm{M}_{\mathrm{L}} \geq 3$ earthquakes between 1940 and 2010 (to account for $\mathrm{M}_{\mathrm{L}}<5$ catalogue incompleteness between 1940 and the late 1980s, we estimate these rates using both recorded events only and events estimated using G-R scaling from $M_{L} 5$ to $M_{L} 3$ with a b value of 1). Collectively, this implies that the CES aftershock sequence has decayed significantly, but is still ongoing, as defined by increased seismicity rates relative to pre-CES 'background' seismicity.

The presence of additional seismic sources in the CES region capable of inducing future earthquakes has been confirmed by land- and marine-based seismic reflection (Barnes et al., 2011; Lawton et al., 2011) and geophysical surveys (Davy et al., 2012). The slip rates, recurrence intervals and $M_{w}$ potentials of earthquakes on these faults remain the focus of future research, however preliminary research suggests slow slip rates $\left(<0.2 \mathrm{~mm} \mathrm{yr}^{-1}\right)$, long recurrence intervals $\left(>10^{3}\right.$ to $10^{4} \mathrm{yrs}$ ), and $\mathrm{M}_{\mathrm{w}}$ potentials ranging from $\sim 5.5$ to $\geq 7$ (Barnes et al., 2011). Given the prior inclusion of 'floating' sources in existing seismic hazard models for this region, the discovery of these faults are unlikely to significantly alter time-invariant probabilistic seismic hazard for the CES region. However, inclusion of these sources may help to refine future seismicity models that combine spatial constraints from Coulomb stress change models with statistical seismicity (e.g., short-term earthquake probability - STEP) (Steacy et al., 2014). The proposed long earthquake recurrence intervals on individual faults in this area suggest that any subsequent proximal $\mathrm{M}_{\mathrm{w}} \geq 5.5$ earthquakes would be scrutinised carefully to discern whether stress changes induced by the CES triggered this event (Steacy et al., 2013). Hybrid operational earthquake forecast models for the CES region (Rhoades et al., 2016) suggest a $49 \%$ annual probability of a $M_{L} \geq 5$ and $6 \%$ annual probability of a $M_{L} \geq 6$ between November 2015 and November 2016. Geologic proxy evidence for strong shaking (Mackey and Quigley, 2014) suggests that strong shaking in Christchurch comparable to that of the $M_{w} 6.2$ and $M_{w} 6.0$ Christchurch earthquakes is relatively rare over geologic timescales, with hiatuses of several $10^{3}$ yrs.

Finally, it is worthwhile comparing the CES to other earthquake sequences in analogous tectonic settings. Estimated aftershock rates within $3 \mathrm{~km}$ of recently ruptured mainshock source faults in eastern California exceed pre-mainshock seismicity rates for time periods ranging from 7 to 66 yrs (Toda et al., 2005), implying that continental aftershock sequences in settings analogous to the CES may continue for decades. The $1999 \mathrm{M}_{\mathrm{w}}$ 7.1 Hector Mine earthquake occurred within close spatial $(50 \mathrm{~km})$ and temporal (7 yrs) proximity to the 1992 Landers earthquake sequence $\left(\mathrm{M}_{\mathrm{w}} 6.1,7.3\right.$, and 6.2 earthquakes) in California; the close succession of major earthquakes on faults with average earthquake recurrence intervals on the order of $>10^{4} \mathrm{yrs}$ (Rockwell et al., 2000) strongly suggests causal linkage relating to stress transfer over many years. Numerous faults in the CES region (Pettinga et al., 2001; Barnes et al., 2011) exist in areas of increased Coulomb stress changes (Steacy et al., 2013); any subsequent earthquakes on these faults will inevitably need to be considered within the context of preceding seismicity including the CES.

\section{Conclusions}

1. The 2010-2011 CES occurred on a series of previously unidentified active faults situated in a comparably low strain rate domain at the periphery of a diffuse plate boundary orogen. The locations of the 14 faults that ruptured in $\mathrm{M}_{\mathrm{w}} 7.1$ to 5.9 earthquakes, including the surface rupturing Greendale Fault, were unknown because (i) evidence for prior surface rupture and surface folding was buried by Late Pleistocene and/or Holocene sediments, and/or was sufficiently subtle or eroded to the point that no surface deformation was clearly discernible from geomorphic or topographic analysis, (ii) detailed subsurface geophysical investigations that had recently revealed similar active blind and buried faults elsewhere in the region had not yet been conducted in the CES region, and (iii) the CES faults were seismically quiescent or had sufficient small and imprecisely located historical earthquakes such that fault structure 
was not clearly definable. However, the susceptibility of the region to a CES-type scenario was well documented in pre-CES seismic hazard models (Stirling et al., 2001, 2008) that stated (i) earthquakes up to $M_{w} 7.2$ on unidentified faults were possible in the region, (ii) proximal moderate $\mathrm{M}_{\mathrm{w}}$ earthquakes contributed the largest component of strong to severe shaking hazard in Christchurch, and (iii) structurally inherited E-W striking active faults were present through the broader region and capable of generating $M_{w}>7$ surface rupturing earthquakes. From this perspective, individual CES earthquakes were consistent with best-practise seismic hazard models (Stirling et al., 2012). The spatial and temporal clustering of this event highlighted the importance of implementing short- to mediumterm forecasting in seismic hazard considerations (Gerstenberger et al., 2014).

2. The CES triggered a variety of geologic, geomorphic, hydrologic, and biologic environmental effects. The occurrence or non-occurrence of a given effect was governed by the seismologic attributes of the associated earthquake (seismic triggering thresholds) and the intrinsic properties of the site (site characteristics) that in some instances were influenced by preceding earthquakes (e.g. water table depth, pore fluid pressures). The geologic variability of the CES region, including late Holocene alluvial and estuarine sediments with shallow water tables, steep pervasively jointed and subhorizontally stratified volcanic bedrock cliffs, and low-elevation coastal plains with active and abandoned stream channels contributed to the diversity of observed effects. The most severe shaking and most severe environmental effects occurred in response to earthquakes sourced from proximal blind faults. Blind fault earthquakes may thus pose the highest seismic shaking hazard and be the most important tectonic drivers of landscape evolution in a variety of environments globally.

3. Some earthquake-induced features at the surface (e.g. landslides, rockfall deposits) or shallow subsurface (liquefaction feeder dikes and sills, fault ruptures) will persist in the geologic record and provide a long-term archive of the CES. Many of these features will be diagnostic of a seismic origin, fewer will enable the seismologic characteristics of the causative earthquake to be discerned (e.g. minimum PGA), a smaller subset of these will enable the distinction to be made between single versus multiple causative earthquakes, and fewer still will enable estimates of the approximate location, $\mathrm{M}_{\mathrm{w}}$, and shaking intensity of the causative earthquake to be derived. Anthropogenic activity will modify, obscure, or erase many of these effects, particularly at the surface (e.g., tree removal, liquefaction ejecta clean up, rockfall scaling).

4. Damaging regional and local earthquakes including blind fault ruptures, earthquake spatial-temporal clustering, earthquake-triggered rockfalls, liquefaction, and subsidence had all occurred in the CES region in historical times. The potential for severe liquefaction in eastern Christchurch had been well documented by geotechnical studies. From the historical, geological, seismologic, and geotechnical perspective, the CES was thus not a surprise. However some of the earthquakes generated strong ground motions with long recurrence intervals and low annual probabilities; for example PGAs recorded in parts of Christchurch during the $\mathrm{M}_{\mathrm{w}} 6.2$ Christchurch and 6.0 June earthquakes have expected recurrence intervals of $>1000$ to 7000 yrs.

5. CES-induced environmental effects were typically most severe at sites where geologic evidence for historic or prehistoric effects is present. Areas of severe CES rockfall contain Holocene rockfall deposits with similar characteristics. Areas of severe CES ground surface manifestation of liquefaction contain evidence for Holocene and historic liquefaction features, including feeder dikes and sills. CES surface rupture on the Greendale Fault reactivated near-surface fractures that previously ruptured in a Late Pleistocene earthquake. Earthquake-induced subsidence and flooding occurred in areas that may have been affected by historic, earthquakeinduced subsidence and flooding. Some distal hydrologic effects mimicked hydrologic effects induced by other historical earthquakes. Other effects of a more subtle or transient nature are similarly likely to have affected by pre-CES seismicity and offer avenues for future research.

6. For proximal, highly vulnerable sites, the severity of liquefaction and rockfall effects incurred in the $M_{w} 6.2$ Christchurch and 6.0 June earthquakes exceed, or are equivalent to, the severity of any preCES effects discernible from the geologic record. Furthermore, some less-susceptible sites where CES effects occurred show no geologic evidence of pre-CES predecessors. Blind fault earthquakes may thus dominate the palaeoseismic record in some locations globally. From the geologic perspective, the CES, and in particular the $M_{w} 6.2$ Christchurch and 6.0 June earthquakes, appears to represent a 'worse case' seismic shaking scenario for the Christchurch area. It is unclear from palaeoseismic data whether the tight temporal cluster of proximal earthquakes experienced during the CES is exceptional or representative; from the geologic record, the possibility of further highly damaging earthquakes in the short to medium term cannot be dismissed.

7. Christchurch was settled upon a highly dynamic landscape prone to flooding and mass movements, in an area where historical earthquakes were frequently recorded, and where geologic evidence for flooding, liquefaction and mass movements was present at the surface or in the shallow subsurface. Extensive property development, largely in the 1950s and 1960s but starting in the late 19th Century and continuing into the 2000s, took place (i) on some of the most vulnerable liquefaction and flood prone areas of Christchurch where evidence for prehistoric liquefaction was present in the shallow subsurface, (ii) within metres of cliff edges where historical cliff erosion had occurred and where geologic evidence for extensive prehistoric cliff erosion was present, and (iii) within metres of the base of bedrock cliffs sites where historic and prehistoric rockfall had occurred. Most of these sites were subsequently red-zoned by central government. In cases of severe recurrent liquefaction, land red-zoning was proposed because repairing the extensive land damage would take a long time, was not feasible on an individual basis, and would require potentially expensive engineering solutions that were not certain to satisfactorily reduce the risk of future damage from liquefaction. In cases of severe mass movements, land redzoning was proposed because estimated annual individual fatality risks due to future rockfall or cliff collapse exceeded values deemed to be societally tolerable. Notable challenges posed by future strong earthquakes include (i) recurrent liquefaction, subsidence and relative sea-level rise, which could be enhanced by eustatic sea-level rise, and which could increase the flooding and inundation hazard posed by urban rivers, storm surges and tsunamis, and (ii) further mass movements. Although the science-informed land use decisions have reduced hazard exposure for the most susceptible parts of Christchurch, ongoing development in high flood hazard areas, large and expensive infrastructural developments in liquefaction vulnerable areas, and the presence of $\sim 100,000$ residents living at elevations $<5$ masl and within $6 \mathrm{~km}$ of Pacific Ocean coastline, including $\sim 4500$ residents living at $0-2 \mathrm{~m}$ above sea-level, collectively highlight some of the future challenges posed to the region.

8. Numerous large cities throughout the world are located in geologic and geomorphic settings similar to Christchurch. In many of these instances, active faults have not been identified, and seismic hazard analyses may not adequately implement proximal blind fault earthquakes into consideration of sources of future seismic shaking hazard. We show here that clues to the high shaking hazard for Christchurch were present in geologic features throughout the study region. In the case of the CES, more attention could have been pre-emptively focused on the search and investigation of 
these features. Even following the $\mathrm{M}_{\mathrm{w}}$ 7.1 Darfield earthquake, the presence of large rockfall deposits at the base of slopes that were only marginally affected by this earthquake provided evidence that stronger shaking from a more proximal fault source was an important scenario to consider, both in the short-term (e.g., aftershocks) and long-term. The challenge of using palaeoseismic data to better inform land use policy and engineering design criteria, with an ultimate goal of reducing fatalities and financial loss, transcends Earth science alone, and is a topic for concerted future efforts.

Supplementary data to this article can be found online at http://dx. doi.org/10.1016/j.tecto.2016.01.044.

\section{Acknowledgements}

We thank the New Zealand Earthquake Commission for the financial support via Capability Funding for this research. In particular Dr. Richard Smith and Dr. Hugh Cowan are thanked for their enthusiastic support of this research. Additional funding from the New Zealand Natural Hazards platform (M.H. and B.B) and the Royal Society of New Zealand (M.Q. and B.B) is also acknowledged. We thank Paul White from GNS Science for provision of 1856 ecosystem data. We are indebted to many of our research postgraduate students for their inspiring efforts to convert earthquake trauma into scientific legacy, in particular we acknowledge Dr. Timothy Stahl, Dr. Eric Bilderback, Dr. Narges Khajavi, Sarah Bastin, Sharon Hornblow, and Duncan Noble. Our collective understanding of earthquakes has profited via collaborative research and discussions with Kevin Furlong, Benjamin Mackey, Russ van Dissen, Nicola Litchfield, Andy Nicol, Pilar Villamor, David Barrell, Russell Green, Martitia Tuttle, Sandy Steacy, Yong-Gang Li, Simon Cox, Chris Massey, and the late John Beavan, amongst many others. We dedicate this research article to the people of Canterbury.

\section{References}

Aagaard, B.T., Hall, J.F., Heaton, T.H., 2004. Effects of fault dip and slip rake angles on nearsource ground motions: why rupture directivity was minimal in the 1999 Chi-Chi, Taiwan, earthquake. Bull. Seismol. Soc. Am. 94, 155-170.

Adams, J., 1980. Paleoseismicity of the Alpine fault seismic gap, New Zealand. Geology 8, $72-76$.

Aguilera, J.G., 1920. The Sonora earthquake of 1887. Bull. Seismol. Soc. Am. 10.

Aki, K., Richards, P.G., 2002. Quantitative Seismology. University Science Books 0-93570296-2 (704pp.)

Allen, J., Davis, C., Giovinazzi, S., Hart, D.E., Cochrane, T., Deam, B., De Pascale, G., Hicks, M., Holland, D., Hughes, M., Johnson, L., Ko, S.Y., Measures, R., Quigley, M., Rix, G. Siembieda, W., Stark, N., Teasley, R., Wotherspoon, L., van Ballegooy, S., 2014. Geotechnical \& flooding reconnaissance of the 2014 March flood event post 2010-2011 Canterbury earthquake sequence. New Zealand. Report No. GEER035. GEER.

Alloway, B.V., Lowe, D.J., Barrell, D.J., Newnham, R.M., Almond, P.C., Augustinus, P.C., Bertler, N.A., Carter, L., Litchfield, N.J., McGlone, M.S., 2007. Towards a climate event stratigraphy for New Zealand over the past 30000 years (NZ-INTIMATE project). J. Quat. Sci. 22, 9-35.

Ambraseys, N.N., 1971. Value of historical records of earthquakes. Nature 232, 375-379.

Ambraseys, N.N., 1988. Engineering seismology. Earthq. Eng. Struct. Dyn. 17, 1-105.

Ambraseys, N.N., Melville, C.P., 1982. A History of Persian Earthquakes. Cambridge university press.

Andrews, D.J., Hanks, T.C., Whitney, J.W., 2007. Physical limits on ground motion at Yucca Mountain: Bull. Seismol. Soc. Am. 7, 1771-1792. http://dx.doi.org/10.1785/012007001.

Arango, I., 1996. Magnitude scaling factors for soil liquefaction evaluations. J. Geotech. Eng. 122 (11), 929-936.

Atwater, B.F., 1987. Evidence for great Holocene earthquakes along the outer coast of Washington State. Science 236, 942-944.

Atzori, S., Tolomei, C., Antonioli, A., Merryman Boncori, J., Bannister, S., Trasatti, E., Pasquali, P., Salvi, S., 2012. The 2010-2011 Canterbury, New Zealand, seismic sequence: multiple source analysis from InSAR data and modeling. J. Geophys. Res. Solid Earth 1978-2012, 117.

Bannister, S., Gledhill, K., 2012. Evolution of the 2010-2012 Canterbury earthquake sequence. N. Z. J. Geol. Geophys. 55, 295-304.

Barbot, S., Lapusta, N., Avouac, J.-P., 2012. Under the hood of the earthquake machine: toward predictive modeling of the seismic cycle. Science 336, 707-710.

Barnes, P., Castellazzi, C., Gorman, A., Wilcox, S., 2011. Submarine faulting beneath Pegasus Bay, Offshore Christchurch. Short-term Canterbury Earthquake Recovery Project 2: offshore faults. National Institute of Water \& Atmosphere (NIWA) Client Report WLG2011 28, 46.
Barrell, D., 2000. Port of Lyttelton tide gauge, geological stability assessment. Institute of Geological \& Nuclear Sciences Science Report, 1171-9184 (2001/20).

Barrell, D., 2010. GNS Science Immediate Report - Darfield (Canterbury) Earthquake of 04 Sept 2010: further reconnaissance of surface deformation - 24 \& 25 October 2010. Unpublished report held by GNS Science, file no. LD8/845. 05 November 2010, p. 12

Barrell, D., Litchfield, N.J., Townsend, D.B., Quigley, M., Van Dissen, R.J., Cosgrove, R., Cox, S.C., Furlong, K., Villamor, P., Begg, J.G., Hemmings-Sykes, S., Jongens, R., Mackenzie, H., Noble, D., Stahl, T., Bilderback, E., Duffy, B., Henham, H., Klahn, A., Lang, E.M.W., Moody, L., Nicol, R., Pedley, K., Smith, A., 2011. Strike-slip ground-surface rupture (Greendale Fault) associated with the 4 September 2010 Darfield earthquake, Canterbury, New Zealand. Q. J. Eng. Geol. Hydrogeol. 44, 283-291.

Bastin, S., Quigley, M., Bassett, K., 2013a. Modern and Paleo-liquefaction Features in Eastern Christchurch and Strategies for Locating Pre-historic Liquefaction. p. 8.

Bastin, S., Reid, C., Quigley, M., Bassett, K., 2013b. Earthquake impacts on soft sediments in Eastern Christchurch. Christchurch Conference, 2013 Field Trip Guides. GSNZ Misc. Pub. 136B.

Bastin, S.H., Quigley, M.C., Bassett, K., 2015. Paleoliquefaction in Christchurch, New Zealand. Geol. Soc. Am. Bull. B31174, 31171.

Bastin, S., Bassett, K., Quigley, M., Maurer, B., Green, R., Bradley, B., Jacobson, D., (in review), unpublished results. Paleo-liquefaction in eastern Canterbury, New Zealand.

Beavan, J., Samsonov, S., Motagh, M., Wallace, L., Ellis, S., Palmer, N, 2010. The Mw 7.1 Darfield (Canterbury) earthquake: geodetic observations and preliminary source model. Bull. N. Z. Soc. Earthq. Eng. 43 (4), 228-235.

Beavan, J., Fielding, E., Motagh, M., Samsonov, S., Donnelly, N., 2011. Fault location and slip distribution of the 22 February 2011 Mw 6.2 Christchurch, New Zealand, earthquake from geodetic data. Seismol. Res. Lett 82 (6), 789-799.

Beavan, J., Motagh, M., Fielding, E.J., Donnelly, N., Collett, D., 2012. Fault slip models of the 2010-2011 Canterbury, New Zealand, earthquakes from geodetic data and observations of postseismic ground deformation. N. Z. J. Geol. Geophys. 55, 207-221.

Bebbington, M., Harte, D., Williams, C., 2015. Cumulative Coulomb stress triggering as an explanation for the Canterbury (New Zealand) aftershock sequence: initial conditions are everything? Pure Appl. Geophys. 1-16.

Begg, J.G., Jones, K.E., Rattenbury, M.S., Barrell, D.J., Ramilo, R., Beetham, D., 2015. A 3D geological model for Christchurch City (New Zealand): a contribution to the postearthquake re-build. Engineering Geology for Society and Territory-Volume 5. Springer, pp. 881-884

Bell, D., Trangmar, B., 1987. Regolith materials and erosion processes on the Port Hills, Christchurch, New Zealand. Fifth International Conference and Field Workshop on Landslides, pp. 93-105.

Berberian, M., 1995. Master "blind" thrust faults hidden under the Zagros folds: active basement tectonics and surface morphotectonics. Tectonophysics 241, 193-224.

Berryman, K., 2012. Geoscience as a component of response and recovery from the Canterbury earthquake sequence of 2010-2011. N. Z. J. Geol. Geophys. 55, 313-319.

Berryman, K., Cooper, A., Norris, R., Villamor, P., Sutherland, R., Wright, T., Schermer, E., Langridge, R., Biasi, G., 2012. Late Holocene rupture history of the Alpine fault in south Westland, New Zealand. Bull. Seismol. Soc. Am. 102, 620-638.

Boatwright, J., 2007. The persistence of directivity in small earthquakes. Bull. Seismol. Soc. Am. 97, 1850-1861.

Borella, J., Quigley, M., Vick, L., unpublished results. Deforestation increases Anthropocene rockfall hazard, in review, Nature Geoscience.

Boulanger, R.W., Idriss, I.M., 2014. CPT and SPT based liquefaction triggering procedures. Center for Geotechnical Modelling, Department of Civil and Environmental Engineering, University of California, Davis, CA. Report No. UCD/CGM-14/01.

Bradley, B.A., 2010. NZ-specific Pseudo-spectral Acceleration Ground Motion Prediction Equations Based on Foreign Models, Department of Civil and Natural Resources Engineering. University of Canterbury, Christchurch, New Zealand (324 pp.).

Bradley, B.A., 2012a. A critical analysis of strong ground motions observed in the 4 September 2010 Darfield earthquake. Soil Dyn. Earthq. Eng.

Bradley, B.A., 2012b. Strong ground motion characteristics observed in the 4 September 2010 Darfield, New Zealand earthquake. Soil Dyn. Earthq. Eng. 42, 32-46.

Bradley, B.A., 2013a. A New Zealand-specific pseudospectral acceleration ground-motion prediction equation for active shallow crustal earthquakes based on foreign models. Bull. Seismol. Soc. Am. 103, 1801-1822.

Bradley, B.A., 2013b. Systematic ground motion observations in the Canterbury earthquakes and region-specific non-ergodic empirical ground motion modeling. Earthquake Spectra.

Bradley, B.A., 2014. Site-specific and spatially-distributed ground-motion intensity estimation in the 2010-2011 Canterbury earthquakes. Soil Dyn. Earthq. Eng. 61-62, 83-91.

Bradley, B.A., 2015. Systematic ground motion observations in the Canterbury earthquakes and region-specific non-ergodic empirical ground motion modelling. Earthquake Spectra 31 (3), 1735-1761.

Bradley, B.A., Cubrinovski, M., 2011a. Near-source strong ground motions observed in the 22 February 2011 Christchurch earthquake. Seismol. Res. Lett. 82, 853-865.

Bradley, B., Cubrinovski, M., 2011b. Near-source strong ground motions observed in the 22 February 2011 Christchurch earthquake. Bull. N. Z. Soc. Earthq. Eng. 44, 181-194.

Bradley, B.A., Quigley, M.C., Van Dissen, R.J., Litchfield, N.J., 2014. Ground motion and seismic source aspects of the Canterbury earthquake sequence. Earthquake Spectra $30,1-15$.

Bradshaw, J.D., 1989. Cretaceous geotectonic patterns in the New Zealand region. Tectonics $8,803-820$

Brown, L.J., Weeber, J.H., 1992. Geology of the Christchurch urban area: Institute of Geological and Nuclear Sciences Geological Map 1. Institute of Geological and Nuclear Sciences Limited, Lower Hutt, New Zealand, scale, $1(25,000) 1$. 
Brown, L., Beetham, R., Paterson, B., Weeber, J., 1995. Geology of Christchurch, New Zealand. Environ. Eng. Geosci. 1, 427-488.

Browne, G., Field, B., Barrell, D., Jongens, R., Bassett, K., Wood, R., 2012. The geological setting of the Darfield and Christchurch earthquakes. N. Z. J. Geol. Geophys. 55, 193-197.

Bull, W.B., Brandon, M.T., 1998. Lichen dating of earthquake-generated regional rockfall events, Southern Alps, New Zealand. Geol. Soc. Am. Bull. 110, 60-84.

Burrato, P., Ciucci, F., Valensise, G., 2003. An inventory of river anomalies in the Po Plain, Northern Italy: evidence for active blind thrust faulting. Ann. Geophys.

Campbell, J., Pettinga, J., Jongens, R., 2012. The tectonic and structural setting of the 4 September 2010 Darfield (Canterbury) earthquake sequence, New Zealand. N. Z. J. Geol. Geophys. 55, 155-168.

Cetin, K.O., Bilge, H.T., 2011. Performance-based assessment of magnitude (duration) scaling factors. J. Geotech. Geoenviron. 138, 324-334.

Clark, K., Hayward, B., Cochran, U., Grenfell, H., Hemphill-Haley, E., Mildenhall, D. Hemphill-Haley, M., Wallace, L., 2011. Investigating subduction earthquake geology along the southern Hikurangi margin using palaeoenvironmental histories of intertidal inlets. N. Z. J. Geol. Geophys. 54, 255-271.

Cochran, U.A., Reid, C.M., Clark, K.J., Litchfield, N.J., Marsden, I., Reis, W., 2014. The AvonHeathcote Estuary as a recorder of coseismic vertical deformation. Earthquake Commission. GNS Science Consultancy Report 2014/128. 50p. + Appendices.

Copini, P., Decuyper, M., Sass-Klaassen, U., Gärtner, H., Mohren, F., den Ouden, J., 2015. Effects of experimental stem burial on radial growth and wood anatomy of pedunculate oak. Dendrochronologia 33, 54-60.

Cowan, H., 1991. The North Canterbury earthquake of September 1, 1888. J. R. Soc. N. Z. $21,1-12$.

Cox, S.C., Barrell, D.J.A., 2007. Geology of the Aoraki Area. Institute of Geological \& Nuclear Sciences.

Cox, S.C., Menzies, C.D., Sutherland, R., Denys, P.H., Chamberlain, C., Teagle, D.A.H., 2015. Changes in hot spring temperature and hydrogeology of the Alpine Fault hanging wall, New Zealand, induced by distal South Island earthquakes. Geofluids 15 (1-2), 216-239.

Cox, S., Rutter, H., Sims, A., Manga, M., Weir, J., Ezzy, T., White, P., Horton, T., Scott, D., 2012. Hydrological effects of the MW 7.1 Darfield (Canterbury) earthquake, 4 September 2010, New Zealand. N. Z. J. Geol. Geophys. 55, 231-247.

Crone, A.J., Omdahl, E.M., 1987. Proceedings of Conference XXXIX; Directions in Paleoseismology, Open-file Report 87-673, - Ed.

Cubrinovski, M., McCahon, I., 2011. Foundations on deep alluvial soils, University of Canterbury, Christchurch. Technical Report Prepared for the Canterbury Earthquakes Royal Commission (40pp.).

Cubrinovski, M., Green, R., Allen, J., Ashford, S., Bowman, E., Bradley, B.A., Cox, B. Hutchinson, T., Kavazanjian, E., Orense, R., Pender, M., Quigley, M., Wotherspoon, L., 2010. Geotechnical reconnaissance of the 2010 Darfield (Canterbury) earthquake. Bull. N. Z. Soc. Earthq. Eng. 43, 243-320.

Cubrinovski, M., Bradley, B.A., Wotherspoon, L., Green, R., Bray, J., Wood, C., Pender, M., Allen, J., Bradshaw, A., Rix, G., Taylor, M., Robinson, K., Henderson, D., Giorgini, S., Ma, K., Winkley, A., Zupan, J., O'Rourke, T.D., DePascale, G., Wells, D.L., 2011a. Geotechnical aspects of the 22 February 2011 Christchurch earthquake. Bull. N. Z. Soc. Earthq. Eng. 44, 205-226.

Cubrinovski, M., Bray, J.D., Taylor, M., Giorgini, S., Bradley, B.A., Wotherspoon, L., Zupan, J., 2011b. Soil liquefaction effects in the central business district during the February 2011 Christchurch earthquake. Seismol. Res. Lett. 82, 893-904.

Cubrinovski, M., Robinson, K., Taylor, M., Hughes, M., Orense, R., 2012. Lateral spreading and its impacts in urban areas in the 2010-2011 Christchurch earthquakes. N. Z. J. Geol. Geophys. 55, 255-269.

Davy, B., Stagpoole, V., Barker, D., Yu, J., 2012. Subsurface structure of the Canterbury region interpreted from gravity and aeromagnetic data. N. Z. J. Geol. Geophys. 55, 185-191.

Deans, J., 1937. Pioneers of Canterbury. Dean S Letters, pp. 1840-1854.

Della Pasqua, F., Massey, C.I., Lukovic, B., Ries, W., Archibald, G., 2014. Canterbury Earthquakes 2010/11 Port Hills Slope Stability: Earth/Debris flow risk assessment for Defender Lane. In: GNS Science Consultancy Report 2014/67, p. 115.

DeMets, C., Gordon, R.G., Argus, D.F., 2010. Geologically current plate motions. Geophys. J. Int. 181 (1), 1-80.

Dorn, C., Green, A., Jongens, R., Carpentier, S., Kaiser, A., Campbell, F., Horstmeyer, H., Campbell, J., Finnemore, M., Pettinga, J., 2010. High-resolution seismic images of potentially seismogenic structures beneath the northwest Canterbury Plains, New Zealand. J. Geophys. Res. Solid Earth 1978-2012, 115.

Downes, G., Yetton, M., 2012. Pre-2010 historical seismicity near Christchurch, New Zealand: the $1869 \mathrm{Mw}$ 4.7-4.9 Christchurch and $1870 \mathrm{Mw}$ 5.6-5.8 Lake Ellesmere earthquakes. N. Z. J. Geol. Geophys. 55 (3), 199-205.

Duffy, B.G., 2012. The Structural and Geomorphic Development of Active Collisional Orogens, from Single Earthquake to Million Year Timescales, Timor Leste and New Zealand. University of Canterbury, Christchurch, New Zealand, p. 238.

Duffy, B., Quigley, M., Barrell, D.J., Van Dissen, R., Stahl, T., Leprince, S., McInnes, C., Bilderback, E., 2013. Fault kinematics and surface deformation across a releasing bend during the 2010 MW 7.1 Darfield, New Zealand, earthquake revealed by differential LiDAR and cadastral surveying. Geol. Soc. Am. Bull. 125, 420-431.

Elliott, J., Nissen, E., England, P., Jackson, J.A., Lamb, S., Li, Z., Oehlers, M., Parsons, B., 2012. Slip in the 2010-2011 Canterbury earthquakes, New Zealand. J. Geophys. Res. Solid Earth 1978-2012, 117.

Fletcher, J.M., Teran, O.J., Rockwell, T.K., Oskin, M.E., Hudnut, K.W., Mueller, K.J., Spelz, R.M., Akciz, S.O., Masana, E., Faneros, G., Fielding, E.J., Leprince, S., Morelan, A.E., Stock, J., Lynch, D.K., Elliott, A.J., Gold, P., Liu-Zeng, J., González-Ortega, A., HinojosaCorona, A., González-Garcia, J., 2014. Assembly of a large earthquake from a complex fault system: surface rupture kinematics of the 4 April 2010 El Mayor-Cucapah (Mexico) Mw 7.2 earthquake. Geosphere 10, 797-827.
Forsyth, P., Barrell, D., Jongens, R., 2008. Geology of the Christchurch Area, Institute of Geological \& Nuclear Sciences 1:250000 Geological Map 16, Lower Hutt, New Zealand.

Fry, B., Gerstenberger, M., 2011. Large apparent stresses from the Canterbury earthquakes of 2010 and 2011. Seismol. Res. Lett. 82, 833-838.

Galli, P., 2000. New empirical relationships between magnitude and distance for liquefaction. Tectonophysics 324, 169-187.

Gerstenberger, M., McVerry, G., Rhoades, D., Stirling, M., 2014. Seismic hazard modeling for the recovery of Christchurch. Earthquake Spectra 30, 17-29.

Ghisetti, F., Sibson, R., 2012. Compressional reactivation of E-W inherited normal faults in the area of the 2010-2011 Canterbury earthquake sequence. N. Z. J. Geol. Geophys. $55,177-184$.

Giardini, D., Woessner, J., Danciu, L., Crowley, H., Cotton, F., Grünthal, G., Pinho, R., Valensise, G., Akkar, S., Arvidsson, R., Basili, R., Cameelbeeck, T., Campos-Costa, A. Douglas, J., Demircioglu, M.B., Erdik, M., Fonseca, J., Glavatovic, B., Lindholm, C., Makropoulous, K., Meletti, C., Musson, R., Pitilakis, K., Sesetyan, K., Stromeyer, D. Stucchi, M., Rovida, A., 2013. Seismic Hazard Harmonization in Europe (SHARE): Online Data Resource. http://dx.doi.org/10.12686/SED-00000001-SHARE (SED00000001-SHARE).

Gledhill, K., Robinson, R., Webb, T., Abercrombie, R., Beavan, J., Cousins, J., EberhartPhillips, D., 2000. The MW 6.2 Cass, New Zealand, earthquake of 24 November 1995: reverse faulting in a strike-slip region. N. Z. J. Geol. Geophys. 43, 255-269.

Gledhill, K., Ristau, J., Reyners, M., Fry, B., Holden, C., 2011. The Darfield (Canterbury, New Zealand) Mw 7.1 earthquake of September 2010: a preliminary seismological report. Seismol. Res. Lett. 82, 378-386.

Grace, K. Liquefaction and Paleoliquefaction in Southern Christchurch. (M.Sc. thesis, in review).

Graves, R.W., Pitarka, A., 2010. Broadband ground-motion simulation using a hybrid approach. Bull. Seismol. Soc. Am. 100, 2095-2123.

Green, R., Cubrinovski, M., Bradley, B.A., Henderson, D., Kailey, P., Robinson, K., Taylor M., Winkley, A., Wotherspoon, L., Orense, R., 2012. Geotechnical Aspects of the Mw6. 22011 Christchurch, New Zealand Earthquake, Geo Congress.[S. 1.]:[sn]. pp. $1700-1709$.

Hampton, S., Cole, J., 2009. Lyttelton Volcano, Banks Peninsula, New Zealand: primary volcanic landforms and eruptive centre identification. Geomorphology 104, 284-298.

Hanks, T.C., Brady, A.G., 1991. The Loma Prieta earthquake, ground motion, and damage in Oakland, Treasure Island, and San Francisco. Bull. Seismol. Soc. Am. 81, 2019-2047.

Harris, S.A., 1983. Infilled fissures in loess, Banks Peninsula, New Zealand. Polarforschung 53, 49-58.

Hartzell, S., Mendoza, C., Ramirez-Guzman, L., Zeng, Y., Mooney, W., 2013. Rupture history of the 2008 Mw 7.9 Wenchuan, China, earthquake: evaluation of separate and joint inversions of geodetic, teleseismic, and strong-motion data. Bull. Seismol. Soc. Am. 103 (1), 353-370. http://dx.doi.org/10.1785/0120120108.

Harvey, M., 1976. An Analysis of the Soil Slips that Occurred on the Port Hills, Canterbury, Between 19-25 August 1975. Soil Science Society of New Zealand.

Hayati, H., Andrus, R., 2009. Updated liquefaction resistance correction factors for aged sands. J. Geotech. Geoenviron.

Hayes, G., Briggs, R., Sladen, A., Fielding, E., Prentice, C., Hudnut, K., Mann, P., Taylor, F., Crone, A., Gold, R., Ito, T., Simons, M., 2010. Complex rupture during the 12 January 2010 Haiti earthquake. Nat. Geosci. 3, 800-805.

Hayward, B.W., Grenfell, H.R., Sabaa, A.T., Carter, R., Cochran, U., Lipps, J.H., Shane, P.R. Morley, M.S., 2006. Micropaleontological evidence of large earthquakes in the past 7200 years in southern Hawke's Bay, New Zealand. Quat. Sci. Rev. 25, 1186-1207.

Hayward, B., Sabaa, A.T., Figueira, B., Reid, C.M., Nomura, R., 2015. Foraminiferal record of the 2010-2011 Canterbury Earthquake Sequence, New Zealand, and its predecessors. Palaeogeogr. Palaeoclimatol. Palaeoecol.

Herman, M.W., Herrmann, R.B., Benz, H.M., Furlong, K.P., 2014. Using regional moment tensors to constrain the kinematics and stress evolution of the 2010-2013 Canterbury earthquake sequence, South Island, New Zealand. Tectonophysics 633, 1-15.

Heron, D., Lukovic, B., Massey, C., Ries, W., McSaveney, M., 2014. GIS modelling in support of earthquake-induced rockfall and cliff collapse risk assessment in the Port Hills. Christchurch. J. Spat. Sci. 59 (2), 313-332.

Holden, C., 2011. Kinematic source model of the 22 February 2011 Mw 6.2 Christchurch earthquake using strong motion data. Seismol. Res. Lett. 82, 783-788.

Holden, C., Beavan, J., Fry, B., Reyners, M., Ristau, J., Van Dissen, R., Villamor, P., Quigley, M., 2011. Preliminary source model of the Mw 7.1 Darfield earthquake from geological, geodetic and seismic data. Proceedings of the Ninth Pacific Conference on Earthquake Engineering, Building an Earthquake-resilient Society, Auckland, New Zealand.

Holt, R., Savage, M., Townend, J., Syracuse, E., Thurber, C., 2013. Crustal stress and fault strength in the Canterbury Plains, New Zealand. Earth Planet. Sci. Lett. 383, 173-181.

Hornblow, S., Quigley, M., Nicol, A., Van Dissen, R., Wang, N., 2014. Paleoseismology of the 2010 M w 7.1 Darfield (Canterbury) earthquake source, Greendale Fault, New Zealand. Tectonophysics 637, 178-190.

Howard, M., Nicol, A., Campbell, J., Pettinga, J.R., 2005. Holocene paleoearthquakes on the strike-slip Porters Pass fault, Canterbury, New Zealand. N. Z. J. Geol. Geophys. 48 (1), 59-74.

Hudnut, K., Borsa, A., Glennie, C., Minster, J.-B., 2002. High-resolution topography along surface rupture of the 16 October 1999 Hector Mine, California, earthquake (Mw 7.1) from airborne laser swath mapping. Bull. Seismol. Soc. Am. 92, 1570-1576.

Hughes, M.W., Quigley, M.C., van Ballegooy, S., Deam, B.L., Bradley, B.A., Hart, D.E., 2015 The sinking city: earthquakes increase flood hazard in Christchurch, New Zealand. GSA Today 25

Ishihara, Kenji, 1985. Stability of natural deposits during earthquakes. In: Proceedings of the 11th International Conference on Soil Mechanics and Foundation Engineering 1. The Netherlands: Balkema, Rotterdam, pp. 321-376. 
Jacoby, G.C., Bunker, D.E., Benson, B.E., 1997. Tree-ring evidence for an AD 1700 Cascadia earthquake in Washington and northern Oregon. Geology 25, 999-1002.

Jacomb, C., 2008. The chronology of Moncks Cave, Canterbury, New Zealand. Records of the Canterbury Museum 22, pp. 45-56.

Jongens, R., Barrell, D., Campbell, J., Pettinga, J., 2012. Faulting and folding beneath the Canterbury Plains identified prior to the 2010 emergence of the Greendale Fault. N. Z. J. Geol. Geophys. 55, 169-176.

Kaiser, A., Holden, C., Massey, C., 2013. Determination of site amplification, polarization and topographic effects in the seismic response of the Port Hills following the 2011 Christchurch earthquake. NZSEE Conference, Wellington, New Zealand.

Keefer, D.K., 2002. Investigating landslides caused by earthquakes-a historical review. Surv. Geophys. 23, 473-510.

Khajavi, N., Quigley, M., McColl, S., Rezanejad, A., 2012. Seismically induced boulder displacement in the Port Hills, New Zealand during the 2010 Darfield (Canterbury) earthquake. N. Z. J. Geol. Geophys. 55, 271-278.

Lacrosse, V., van Ballegooy, S., Bradley, B.J., 2015. Effect of liquefaction triggering uncertainty on liquefaction consequence assessments. Proceedings of the 6th International Conference on Earthquake Geotechnical Engineering. ISSMGE, Christchurch, New Zealand.

Lawrie, A., 1993. Shore platforms at $+6-8 \mathrm{~m}$ above mean sea level on Banks Peninsula and implications for tectonic stability. N. Z. J. Geol. Geophys. 36, 409-415.

Lawson, A.C., Reid, H.F., 1908. The California Earthquake of April 18, 1906: Report of the State Earthquake Investigation Commission. Carnegie Institution of Washington.

Lawton, D., Bertram, M., Hall, K., Bertram, K., Pettinga, J., 2011. Post-earthquake seismic reflection survey, Christchurch, New Zealand. CREWES Research Report vol. 23, pp. 1-16.

Lee, W., Brillinger, D., 1979. On Chinese earthquake history-an attempt to model an incomplete data set by point process analysis. Pure Appl. Geophys. 117, 1229-1257.

Leeves, J., van Ballegooy, S., Wentz, R., Lees, J., 2015. Effect of fines content correlation and liquefaction susceptibility thresholds on liquefaction consequence assessments. Proceedings of the 6th International Conference on Earthquake Geotechnical Engineering. ISSMGE, Christchurch, New Zealand.

Leon, E., Gassman, S., Talwani, P., 2006. Accounting for soil aging when assessing liquefaction potential. J. Geotech. Geoenviron.

Li, Y.-G., De Pascale, G.P., Quigley, M.C., Gravley, D.M., 2014. Fault damage zones of the M7.1 Darfield and M6. 3 Christchurch earthquakes characterized by fault-zone trapped waves. Tectonophysics 618, 79-101.

Lisowski, M., Prescott, W., Savage, J., Johnston, M., 1990. Geodetic estimate of coseismic slip during the 1989 Loma Prieta, California, earthquake. Geophys. Res. Lett. 17 $1437-1440$

Litchfield, N., Van Dissen, R., Sutherland, R., Barnes, P., Cox, S., Norris, R., Beavan, R. Langridge, R., Villamor, P., Berryman, K., 2014. A model of active faulting in New Zealand. N. Z. J. Geol. Geophys. 57, 32-56.

Mackey, B.H., Quigley, M.C., 2014. Strong proximal earthquakes revealed by cosmogenic ${ }^{3}$ He dating of prehistoric rockfalls, Christchurch, New Zealand. Geology 42, 975-978.

Main, I., 1996. Statistical physics, seismogenesis, and seismic hazard. Rev. Geophys. 34 433-462.

Mallet, R., 1862. Great Neapolitan Earthquake of 1857: The First Principles of Observationa Seismology. Chapman and Hall.

Marco, S., Stein, M., Agnon, A., Ron, H., 1996. Long-term earthquake clustering: a 50,000 year paleoseismic record in the Dead Sea graben. J. Geophys. Res. 101, 6179-6191.

Massey, C.I., McSaveney, M.J., Taig, T., Richards, L., Litchfield, N.J., Rhoades, D.A., McVerry, G.H., Lukovic, B., Heron, D.W., Ries, W., Van Dissen, R.J., 2014. Determining rockfall risk in Christchurch using rockfalls triggered by the 2010-2011 Canterbury earthquake sequence. Earthquake Spectra 30, 155-181.

Massonnet, D., Rossi, M., Carmona, C., Adragna, F., Peltzer, G., Feigl, K., Rabaute, T., 1993. The displacement field of the Landers earthquake mapped by radar interferometry. Nature 364, 138-142.

Maurer, B.W., Green, R., Cubrinovski, M., Bradley, B., 2014a. Fines-content effects on liquefaction hazard evaluation for infrastructure in Christchurch, New Zealand. Soil Dynamics and Earthquake Engineering

Maurer, B.W., Green, R.A., Cubrinovski, M., Bradley, B.A., 2014b. Evaluation of the liquefaction potential index for assessing liquefaction hazard in Christchurch, New Zealand. J. Geotech. Geoenviron.

Maurer, B.W., Green, R.A., Cubrinovski, M., Bradley, B.A., 2014c. Assessment of aging correction factors for liquefaction resistance at sites of recurrent liquefaction. Anchorage Alaska: Tenth U.S. National Conference on Earthquake Engineering.

Maurer, B.W., Green, R.A., Quigley, M.C., Bastin, S., 2015. Development of magnitudebound relations for paleoliquefaction analyses: New Zealand case study. Eng. Geol. $197,253-266$

McCalpin, J.P., 2009. Paleoseismology. Academic Press.

McKay, A., 1890. On the earthquakes of September 1888, in the Amuri and Marlborough districts of the South Island, NZ. Geol. Surv. Rep. Geol. Explor. 20, 1-16.

Measures, R., Hicks, M., Shankar, U., Bind, J., Arnold, J., Zeldis, J., 2011. Mapping earthquake induced topographical change and liquefaction in the Avon-Heathcote Estuary. NIWA Client Report CHC11-066 (28p.).

Michetti, A., Esposito, E., Guerrieri, L., Porfido, S., Serva, L., Tatevossian, R., Vittori, E. Audemard, F., Azuma, T., Clague, J., 2007. Environmental Seismic Intensity Scale-ES 2007. Memorie descrittive della carta geologica d'Italia 74, p. 41.

Möller, I., Spencer, T., French, J., Leggett, D., Dixon, M., 1999. Wave transformation ove salt marshes: a field and numerical modelling study from North Norfolk, England. Estuar. Coast. Shelf Sci. 49, 411-426.

Morgenroth, J., Armstrong, T., 2012. The impact of significant earthquakes on Christchurch, New Zealand's urban forest. Urban For. Urban Green. 11, 383-389.

Morgenroth, J., Almond, P., Scharenbroch, B.C., Wilson, T.M., Sharp-Heward, S., 2014. Soil profile inversion in earthquake-induced liquefaction-affected soils and the potentia effects on urban trees. Geoderma 213, 155-162.
Nelson, A.R., Kelsey, H.M., Witter, R.C., 2006. Great earthquakes of variable magnitude at the Cascadia subduction zone. Quat. Res. 65, 354-365.

Nicol, A., 1993. Haumurian (c. 66-80 Ma) half-graben development and deformation, mid Waipara, North Canterbury, New Zealand. N. Z. J. Geol. Geophys. 36, 127-130.

Nicol, A., Begg, J., Mouslopoulou, V., Stirling, M., Townsend, D., Van Dissen, R., Walsh, J., 2011. Active faults in New Zealand: what are we missing? Geological Society of New Zealand Annual Conference, Nelson, New Zealand

Ogata, Y., 1988. Statistical models for earthquake occurrences and residual analysis for point processes. J. Am. Stat. Assoc. 83, 9-27.

Oldham, R.D., 1899. Report of the Great Earthquake of 12th June, 1897. Office of the Geological Survey.

Oskin, M.E., Arrowsmith, J.R., Corona, A.H., Elliott, A.J., Fletcher, J.M., Fielding, E.J., Gold, P.O., Garcia, J.J.G., Hudnut, K.W., Liu-Zeng, J., Teran, O.J., 2012. Near-field deformation from the El Mayor-Cucapah earthquake revealed by differential LiDAR. Science 335, 702-705.

Oth, A., Kaiser, A.E., 2014. Stress release and source scaling of the 2010-2011 Canterbury, New Zealand Earthquake sequence from spectral inversion of ground motion data. Pure Appl. Geophys. 171, 2767-2782.

Ozacar, A.A., Beck, S.L., 2004. The 2002 Denali fault and 2001 Kunlun fault earthquakes: complex rupture processes of two large strike-slip events. Bull. Seismol. Soc. Am. 94, S278-S292.

Petersen, M.D., Frankel, A.D. Harmsen, S.C., Mueller, C.S., Haller, K.M., Wheeler, R.L. Wesson, R.L. Zeng Y. Boyd, O.S. Perkins, D.M., Luco, N. Field, E.H. Wills, C.. Rukstales, K.S., 2008. Documentation for the 2008 update of the United States national seismic hazard maps. Open-file Report 2008-1128. United States Geological Survey.

Pettinga, J.R., Yetton, M.D., Van Dissen, R.J., Downes, G., 2001. Earthquake source identification and characterisation for the Canterbury region, South Island, New Zealand. Bull. N. Z. Natl. Soc. Earthq. Eng. 34, 282-317.

Price, E.J., Bürgmann, R., 2002. Interactions between the Landers and Hector Mine, California, earthquakes from space geodesy, boundary element modeling, and timedependent friction. Bull. Seismol. Soc. Am. 92, 1450-1469.

Quigley, M., 2013. Earthquake clustering, complex fault ruptures, and the geologic record. Speaking of Geoscience: Geological Society of America's Guest Blog.

Quigley, M., Clark, D., Sandiford, M., 2010a. Tectonic geomorphology of Australia. Geological Society London Special Publication 'Australian Landscapes' v. 346, pp. 243-265. http://dx.doi.org/10.1144/SP346.13.

Quigley, M., Cupper, M., Sandiford, M., 2006. Quaternary faults of south-central Australia: palaeoseismicity, slip rates and origin. Aust. J. Earth Sci. 53, 285-301.

Quigley, M., Van Dissen, R., Villamor, P., Litchfield, N., Barrell, D., Furlong, K., Stahl, T., Duffy, B., Bilderback, E., Noble, D., Townsend, D., Begg, J., Jongens, R., Ries, W., Claridge, J., Klahn, A., Mackenzie, H., Smith, A., Hornblow, S., Nicol, A., Cox, S., Langridge, R., Pedley, K., 2010b. Surface rupture of the Greendale fault during the Darfield (Canterbury) earthquake, New Zealand: initial findings. Bull. N. Z. Soc. Earthq. Eng. 43, 236

Quigley, M., Villamor, P., Furlong, K., Beavan, J., Van Dissen, R., Litchfield, N., Stahl, T., Duffy, B., Bilderback, E., Noble, D., Barrell, D., Jongens, R., Cox, S., 2010c. Previously unknown fault shakes New Zealand's South Island. EOS Trans. Am. Geophys. Union 91, 469-471

Quigley, M., Van Dissen, R., Litchfield, N., Villamor, P., Duffy, B., Barrell, D., Furlong, K., Stahl, T., Bilderback, E., Noble, D., 2012. Surface rupture during the $2010 \mathrm{Mw} 7.1$ Darfield (Canterbury) earthquake: implications for fault rupture dynamics and seismic-hazard analysis. Geology 40, 55-58.

Quigley, M.C., Bastin, S., Bradley, B.A., 2013. Recurrent liquefaction in Christchurch, New Zealand, during the Canterbury earthquake sequence. Geology 41, 419-422.

Rathje, E., Wang, Y., Stafford, P., Antonakos, G., Saygili, G., 2013. Probabilistic assessment of the seismic performance of earth slopes. Bull. Earthq. Eng. 12, 1071-1090. http:// dx.doi.org/10.1007/s10518-013-9485-9.

Reid, H., 1910. The Mechanics of the Earthquake: The California Earthquake of April 18, 1906, Report, Vol. 2. Carnegie Institution of Washington, Washington, DC (192 pp.).

Reid, C., Thompson, N., Irvine, J., Laird, T., 2012. Sand volcanoes in the Avon-Heathcote estuary produced by the 2010-2011 Christchurch earthquakes: implications for geological preservation and expression. N. Z. J. Geol. Geophys. 55, 249-254.

Reyners, M., Eberhart-Phillips, D., Martin, S., 2014. Prolonged Canterbury earthquake sequence linked to widespread weakening of strong crust. Nat. Geosci. 7, 34-37.

Rhoades, D.A., Liukis, M., Christophersen, A., Gerstenberger, M.C., 2016. Retrospective tests of hybrid operational earthquake forecasting models for Canterbury. Geophys. J. Int. 204 (1), 440-456.

Ristau, J., Holden, C., Kaiser, A., Williams, C., Bannister, S., Fry, B., 2013. The Pegasus Bay aftershock sequence of the Mw 7.1 Darfield (Canterbury), New Zealand earthquake. Geophys. J. Int. 195, 444-459.

Robinson, R., McGinty, P.J., 2000. The enigma of the Arthur's Pass, New Zealand, earthquake: 2 . The aftershock distribution and its relation to regional and induced stress fields. J. Geophys. Res. Solid Earth 105, 16139-16150.

Robinson, K., Cubrinovski, M., Bradley, B.A., 2014. Lateral spreading displacements from the 2010 Darfield and 2011 Christchurch earthquakes. Int. J. Geotech. Eng. 8, 441-448.

Rockwell, T., Lindvall, S., Herzberg, M., Murbach, D., Dawson, T., Berger, G., 2000, Paleoseismology of the Johnson Valley, Kickapoo, and Homestead Valley faults: clustering of earthquakes in the eastern California shear zone. Bull. Seismol. Soc. Am. 90, 1200-1236.

Rogers, N., van Ballegooy, S., Williams, K., Johnson, L., 2015. Considering post-disaster damage to residential building construction - is our modern building construction resilient? Proceedings of the 6th International Conference on Earthquake Geotechnical Engineering. ISSMGE, Christchurch, NZ

Russell, J., van Ballegooy, S., Rogers, N., Lacrosse, V., Jacka, M., 2015. The effect of subsidence on liquefaction vulnerability following the 2010-2011 Canterbury Earthquake 
Sequence. Proceedings of the 12th Australia New Zealand Conference on Geomechanics. NZGS \& AGS, Wellington, New Zealand, pp. 610-617.

Sarconi, M., 1784. Osservazioni fatte nelle Calabrie e nella frontiera di Valdemone sui fenomeni del tremuoto del 1783 e sulla geografia fisica di quelle regioni. R. Accad. Sci.

Schnelle, M., Feucht, J.R., Klett, J., 1989. Root systems of trees-facts and fallacies. J. Arboric. $15,201-205$

Shakal, A., Haddadi, H., Graizer, V., Lin, K., Huang, M., 2006. Some key features of the strong-motion data from the M 6.0 Parkfield, California, earthquake of 28 September 2004. Bull. Seismol. Soc. Am. 96, S90-S118.

Shaw, J., Suppe, J., 1996. Earthquake hazards of active blind-thrust faults under the central Los Angeles basin, California. J. Geophys. Res. 101, 8623-8642.

Shcherbakov, R., Nguyen, M., Quigley, M., 2012. Statistical analysis of the 2010 MW 7.1 Darfield Earthquake aftershock sequence. N. Z. J. Geol. Geophys. 55, 305-311.

Shigo, A.L., 1984. Compartmentalization: a conceptual framework for understanding how trees grow and defend themselves. Annu. Rev. Phytopathol. 22, 189-214.

Silva, W., 1997. Characteristics of vertical strong ground motions for applications to engineering design, FHWA, NCEER workshop on the National Representation of Seismic Ground Motion for New and Existing Highway Facilities, Burlingame, CA. Proceedings, National Center for Earthquake Engineering Research, Technical Report NCEER-97-0010, Buffalo, New York.

Sims, J.D., Garvin, C.D., 1995. Recurrent liquefaction induced by the 1989 Loma Prieta earthquake and 1990 and 1991 aftershocks: implications for paleoseismicity studies. Bull. Seismol. Soc. Am. 85, 51-65.

Somerville, P., Saikia, C., Wald, D., Graves, R., 1996. Implications of the Northridge earthquake for strong ground motions from thrust faults. Bull. Seismol. Soc. Am. 86, S115-S125.

Stahl, T., Bilderback, E.L., Quigley, M.C., Nobes, D.C., Massey, C.I., 2014. Coseismic landsliding during the M w 7.1 Darfield (Canterbury) earthquake: implications for paleoseismic studies of landslides. Geomorphology 214, 114-127.

Steacy, S., Jiménez, A., Holden, C., 2013. Stress triggering and the Canterbury earthquake sequence. Geophys. J. Int. 196, 473-480.

Steacy, S., Gerstenberger, M., Williams, C., Rhoades, D., Christophersen, A., 2014. A new hybrid Coulomb/statistical model for forecasting aftershock rates. Geophys. J. Int 196 (2), 918-923.

Stephen-Brownie, C.J., 2012. Earthquake-induced Ground Fissuring in Foot-slope Positions of the Port Hills, Christchurch, Geological Sciences. University of Canterbury, Christchurch, New Zealand.

Stirling, M., Pettinga, J., Berryman, K.R., Yetton, M.D., 2001. Probabilistic seismic hazard assessment of the Canterbury region, New Zealand. Bull. N. Z. Natl. Soc. Earthq. Eng. 34, 318-334.

Stirling, M., Gerstenberger, M., Litchfield, N., McVerry, G., Smith, W., Pettinga, J., Barnes, P., 2008. Seismic hazard of the Canterbury region, New Zealand: new earthquake source model and methodology. Bull. N. Z. Natl. Soc. Earthq. Eng. 41, 51-65.

Stirling, M., McVerry, G., Gerstenberger, M., Litchfield, N., Van Dissen, R., Berryman, K., Barnes, P., Wallace, L., Villamor, P., Langridge, R., Lamarche, G., Nodder, S., Reyners, M., Bradley, B.A., Rhoades, D., Smith, W., Nicol, A., Pettinga, J., Clark, K., Jacobs, K., 2012. National seismic hazard model for New Zealand: 2010 update. Bull. Seismol. Soc. Am. 102, 1514-1542.

Sutherland, R., Eberhart-Phillips, D., Harris, R., Stern, T., Beavan, J., Ellis, S., Henrys, S., Cox, S., Norris, R., Berryman, K., Townend, J., Bannister, S., Pettinga, J., Leitner, B., Wallace, L., Little, T.A., Cooper, A.F., Yetton, M., Stirling, M., 2007. Do great earthquakes occur on the Alpine fault in central South Island, New Zealand? In: Okaya, D.A., Stern, T.A., Davey, F.J. (Eds.), A Continental Plate Boundary: Tectonics at South Island, New Zealand. Americal Geophysical Union, Washington, D.C., pp. 235-251

Syracuse, E., Holt, R., Savage, M., Johnson, J., Thurber, C., Unglert, K., Allan, K., Karaliyadda, S., Henderson, M., 2012. Temporal and spatial evolution of hypocentres and anisotropy from the Darfield aftershock sequence: implications for fault geometry and age. N. Z. J. Geol. Geophys. 55, 287-293.

Syracuse, E., Thurber, C., Rawles, C., Savage, M., Bannister, S., 2013. High-resolution relocation of aftershocks of the Mw 7.1 Darfield, New Zealand, earthquake and implications for fault activity. J. Geophys. Res. Solid Earth 118, 4184-4195.

Toda, S., Stein, R.S., Richards-Dinger, K., Bozkurt, S.B., 2005. Forecasting the evolution of seismicity in southern California: Animations built on earthquake stress transfer. J. Geophys. Res. Solid Earth 110 (B5)

Tonkin \& Taylor Limited, 2013. Liquefaction Vulnerability Study. Report to Earthquake Commission. Tonkin \& Taylor Ltd. Report 52020.0200/v1.0. February 2013. (Retrieved from) https://canterburygeotechnicaldatabase.projectorbit.com.

Townsend, D., Rosser, B., 2012. Canterbury earthquakes 2010/2011 Port Hills slope stability: geomorphology mapping for rockfall risk assessment. Unpublished GNS Science Consultancy Report 2015/15, p. 21p + maps.

Trifunac, M., Todorovska, M., 2001. Evolution of accelerographs, data processing, strong motion arrays and amplitude and spatial resolution in recording strong earthquake motion. Soil Dyn. Earthq. Eng. 21, 537-555.

van Ballegooy, S., Berryman, K., Deam, B., Jacka, M., 2014a. Repeated major episodes of tectonic deformation, lateral spread and liquefaction in Christchurch during the Canterbury Earthquake Sequence of 2010-2011. Engineering Geology for Society and Territory vol. 5. Springer, pp. 1043-1049.

van Ballegooy, S., Cox, S.C., Thurlow, C., Rutter, H.K., Reynolds, T., Harrington, G., Smith, T. 2014b. Median water elevation in Christchurch and surrounding area after the 4 September 2010 Darfield Earthquake, Version 2. GNS Science Report 2014/18.

van Ballegooy, S., Malan, P., Lacrosse, V., Jacka, M., Cubrinovski, M., Bray, J., O'Rourke, T., Crawford, S., Cowan, H., 2014c. Assessment of liquefaction-induced land damage for residential Christchurch. Earthquake Spectra 30, 31-55.

van Ballegooy, S., Green, R., Lees, J., Wentz, R., Maurer, B., 2015a. Assessment of various CPT based liquefaction severity index frameworks relative to the Ishihara (1985)
$\mathrm{H}_{1}-\mathrm{H}_{2}$ boundary curves. Soil Dynamics and Earthquake Engineering, Special Issue: Liquefaction in New Zealand and Japan.

van Ballegooy, S., Lacrosse, V., Simpson, J., Malan, P., 2015b. Comparison of CPT-based simplified liquefaction assessment methodologies based on Canterbury Geotechnical Dataset. Proceedings of the 12th Australia New Zealand Conference on Geomechanics. NZGS \& AGS, Wellington, New Zealand, pp. 618-625.

Van Dissen, R., Barrell, D., Litchfield, N., Villamor, P., Quigley, M., King, A., Furlong, K., Begg, J., Townsend, D., Mackenzie, H., Stahl, T., Noble, D., Duffy, B., Bilderback, E., Claridge, J. Klahn, A., Jongens, R., Cox, S., Langridge, R., Ries, W., Dhakal, R., Smith, A., Hornblow, S., Nicol, R., Pedley, K., Henham, H., Hunter, R., Zajac, A., Mote, T., 2011. Surface rupture displacement on the Greendale Fault during the Mw 7.1 Darfield (Canterbury) earthquake, New Zealand, and its impact on man-made structures. Ninth Pacific Conference on Earthquake Engineering: Building an Earthquake-resilient Society, Auckland, New Zealand.

Van Dissen, R., Hornblow, S., Quigley, M., Litchfield, N., Villamor, P., Nicol, A., 2013. Towards the development of design curves for characterising distributed strike-slip surface fault rupture displacement: an example from the 4 September. Greendale Fault rupture. Proc. 19th NZGS Geol. Symp., NZ 8 p.

Vere-Jones, D., Ozaki, T., 1982. Some examples of statistical estimation applied to earthquake data. Ann. Inst. Stat. Math. 34, 189-207.

Vettoretti, G.J., 2014. Intertidal foraminifera of the Avon-Heathcote Estuary; response to coseismic deformation and potential to record local historic events. Geological Sciences. University of Canterbury, Christchurch, New Zealand.

Villamor, P., Litchfield, N., Barrell, D., Van Dissen, R., Hornblow, S., Quigley, M., Levick, S., Ries, W., Duffy, B., Begg, J., Townsend, D., Stahl, T., Bilderback, E., Noble, D. Furlong, K., Grant, H., 2012. Map of the 2010 Greendale Fault surface rupture, Canterbury, New Zealand: application to land use planning. N. Z. J. Geol. Geophys. $55,223-230$.

Villamor, P., Giona-Bucci, M., Almond, P., Tuttle, M., Langridge, R., Clark, K., Ries, W. Vandergoes, M., Barker, P.A., Martin, F., Bastin, S., Watson, M., Howarth, J., Quigley, M., 2014. Exploring methods to assess paleoliquefaction in the Canterbury area. GNS Science Consultancy Report 2014/183 (142 pp.).

Villamor, P., Almond, P., Tuttle, M., Giona-Bucci, M., Langridge, R., Clark, K., Ries, W., Bastin, S., Eger, A., Vandergoes, M., Quigley, M., Barker, P., Martin, F., Howarth, J., 2016. Liquefaction features produced by the 2010-2011 Canterbury earthquake sequence in southwest Christchurch, New Zealand and preliminary assessment of paleoliquefaction features. Bull. Seismol. Soc. Am.

Villemure, M., Wilson, T., Bristow, D., Gallagher, M., Giovinazzi, S., Brown, C., 2012. Liquefaction ejecta clean-up in Christchurch during the 2010-2011 earthquake sequence. New Zealand Society for Earthquake Engineering Annual Technical Conference, Christchurch, New Zealand.

Vincke, C., Delvaux, B., 2005. Porosity and available water of temporarily waterlogged soils in a Quercus robur (L.) declining stand. Plant Soil 271, 189-203.

Wald, D.J., Quitoriano, V., Heaton, T.H., Kanamori, H., 1999. Relationships between peak ground acceleration, peak ground velocity, and modified Mercalli intensity in California. Earthquake Spectra 15, 557-564.

Wallace, R.E., 1987. Grouping and migration of surface faulting and variations in slip rates on faults in the Great Basin province. Bull. Seismol. Soc. Am. 77, 868-876.

Wallace, L.M., Beavan, J., McCaffrey, R., Berryman, K., Denys, P., 2007. Balancing the plate motion budget in the South Island, New Zealand using GPS, geological and seismological data. Geophys. J. Int. 168, 332-352.

Walsh, C., Moohan, S., 2011. Effects on trees of the recent Christchurch earthquakes. Tree Matters 13, 11-16

Wells, D.L., Coppersmith, K.J., 1994. New empirical relationships among magnitude rupture length, rupture width, rupture area, and surface displacement. Bull. Seismol. Soc. Am. 84, 974-1002.

Wells, A., Yetton, M.D., 2004. Earthquake tree-ring impacts in the Middle and Upper Buller River catchment. New Zealand Earthquake Commission Research Report 03/ 492 (39pp.).

Wells, A., Yetton, M.D., Duncan, R.P., Stewart, G.H., 1999. Prehistoric dates of the most recent Alpine fault earthquakes, New Zealand. Geology 27, 995-998.

Wesnousky, S.G., 2008. Displacement and geometrical characteristics of earthquake surface ruptures: issues and implications for seismic-hazard analysis and the process of earthquake rupture. Bull. Seismol. Soc. Am. 98, 1609-1632.

Williams, P.W., McGlone, M., Neil, H., Zhao, J.-X., 2015. A review of New Zealand palaeoclimate from the last interglacial to the global last glacial maximum. Quat. Sci. Rev. 110, 92-106.

Wilson, K., Berryman, K., Cochran, U., Little, T., 2007. Early Holocene paleoseismic history at the Pakarae locality, eastern North Island, New Zealand, inferred from transgressive marine sequence architecture. Tectonics 26.

Wotherspoon, L.M., Pender, M.J., Orense, R.P., 2012. Relationship between observed liquefaction at Kaiapoi following the 2010 Darfield earthquake and former channels of the Waimakariri River. Eng. Geol. 125, 45-55.

Yetton, M.D., Wells, A., Traylen, N.J., 1998. The probability and consequences of the next Alpine fault earthquake. New Zealand Earthquake Commission Research Report 95/ 193 (161pp).

Youd, T., Idriss, I., Andrus, R.D., Arango, I., Castro, G., Christian, J.T., Dobry, R., Finn, W.L., Harder Jr., L.F., Hynes, M.E., Ishihara, K., Koester, J., Liao, S., Marcuson III, W., Martin, G.R., Mitchell, J.K., Moriwaki, Y., Power, M.S., Robertson, P.K., Seed, R.B., Stokoe, K.H. 2001. Liquefaction resistance of soils: summary report from the 1996 NCEER and 1998 NCEER/NSF workshops on evaluation of liquefaction resistance of soils. J. Geotech. Geoenviron. 127, 817-833.

Zeldis, J., Skilton, J., South, P., Schiel, D., 2011. Effects of the Canterbury earthquakes on Avon-Heathcote Estuary/Ihutai ecology. Environment Canterbury Technical Report U11/14 (31p.7). 